\title{
The Prehistoric Components at the Rubin Hancock Farmstead, 41TV875, Travis County, Texas
}

\author{
E. Frances Gadus \\ Marie E. Blake \\ Karl W. Kibler \\ Cross Timbers Geoarcheological Services
}

Follow this and additional works at: https://scholarworks.sfasu.edu/ita

Part of the American Material Culture Commons, Archaeological Anthropology Commons, Environmental Studies Commons, Other American Studies Commons, Other Arts and Humanities Commons, Other History of Art, Architecture, and Archaeology Commons, and the United States History Commons

Tell us how this article helped you.

This Article is brought to you for free and open access by the Center for Regional Heritage Research at SFA ScholarWorks. It has been accepted for inclusion in Index of Texas Archaeology: Open Access Gray Literature from the Lone Star State by an authorized editor of SFA ScholarWorks. For more information, please contact cdsscholarworks@sfasu.edu. 


\section{The Prehistoric Components at the Rubin Hancock Farmstead, 41TV875, Travis County, Texas}

\section{Licensing Statement}

This is a work produced for the Texas Department of Transportation (TxDOT) by the report producer. TxDOT and the report producer jointly own all rights, title, and interest in and to all intellectual property developed under TXDOT's contract with the report producer. The report may be cited and brief passages from this publication may be reproduced without permission provided that credit is given to both TXDOT and the report producer. Permission to reprint an entire chapter, section, figures or tables must be obtained in advance from either the Supervisor of the Archeological Studies Branch, Environmental Affairs Division, Texas Department of Transportation, 125 East 11th Street, Austin, Texas, 78701 or from the report producer. 
THE PREHISTORIC COMPONENTS AT THE RUBIN HANCOCK

FARMSTEAD, 41TV875, TRAVIS COUNTY, TEXAS

\author{
by \\ E. Frances Gadus \\ Marie E. Blake \\ and \\ Karl W. Kibler
}

Principal Investigator: Ross C. Fields

TECHNICAL REPORTS, NUMBER 44

Prewitt and Associates, Inc. Cultural Resources Services

Austin, Texas

ARCHEOLOGY STUDIES PROGRAM, REPORT 18

Texas Department of Transportation

Environmental Affairs Division

December 1999

ISBN 0-9660796-7-1

TEXAS ANTIQUITIES COMMITTEE ARCHEOLOGY PERMIT NO. 630 


\section{CONTRACT DATA}

The preparation of this document was accomplished under Order No. 8-0331, Req. No. 60129-881270-B, with the Texas Department of Transportation, Environmental Affairs Division, 125 E. 11th Street, Austin, Texas, 78701-2483. 


\section{TABLE OF CONTENTS}

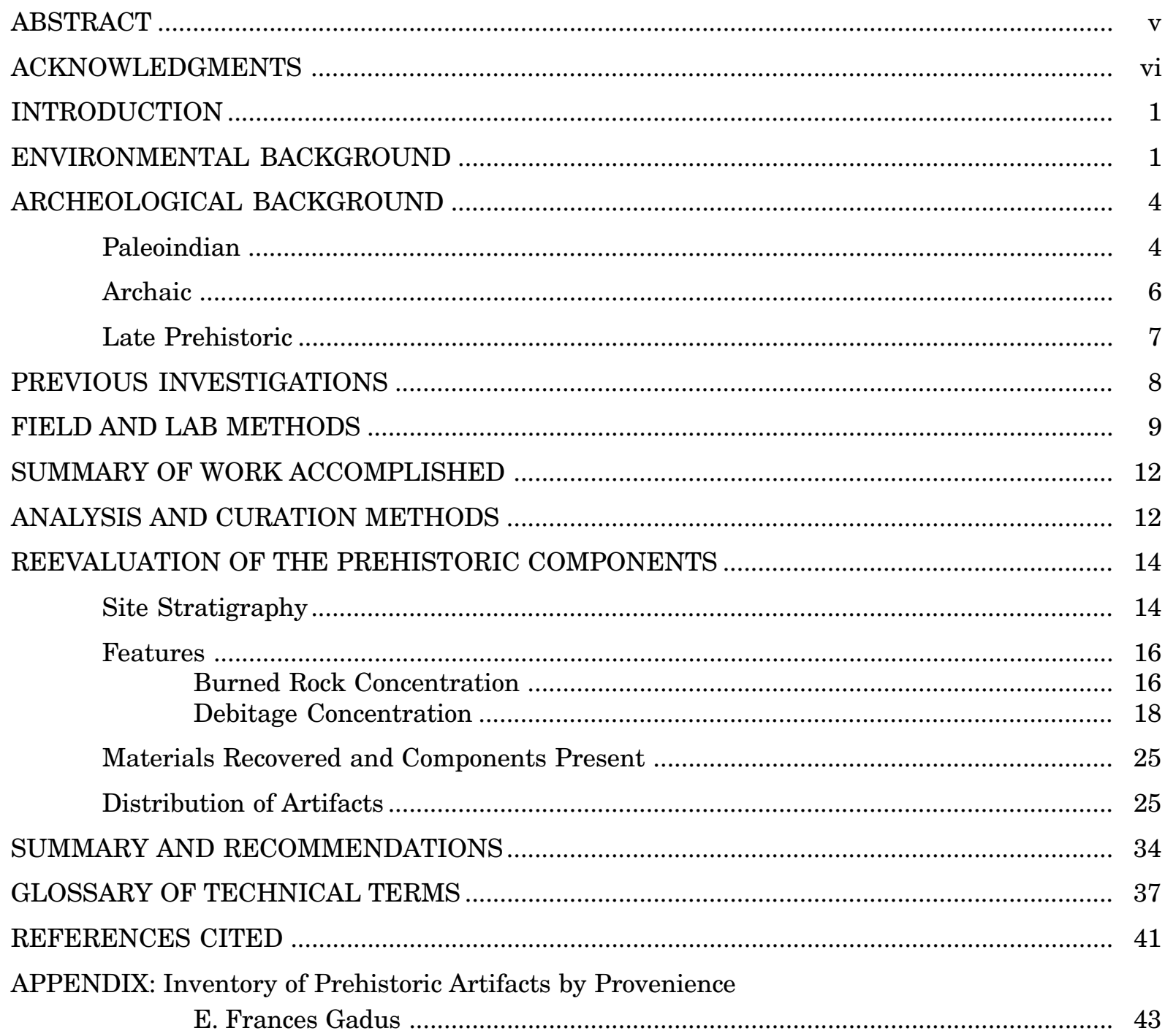




\section{LIST OF FIGURES}

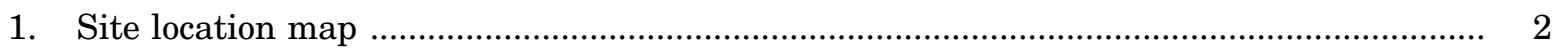

2. Prehistoric cultural sequences ..................................................................................... 5

3. Site plan and depth of excavations ......................................................................... 10

4. North profile of Units E586+95/N175 and E587+00/N175 ........................................... 15

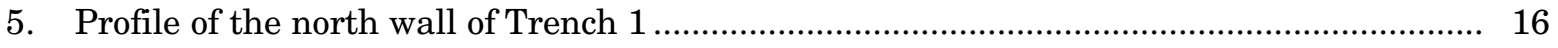

6. Plan of the burned rock concentration and debitage concentration in the excavation

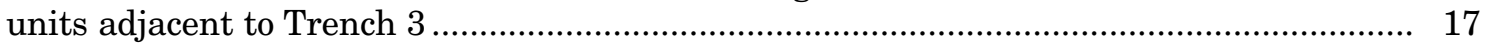

7. Cross section of burned rock concentration along the N161 grid line .............................. 19

8. Debitage concentration exposed at ca. $1.5 \mathrm{ft}$ below the surface in E586+90/N175 ............ 20

9. Type 1 flakes from debitage concentration ...................................................................... 22

10. Flake Types 2 and 3 from debitage concentration ........................................................... 23

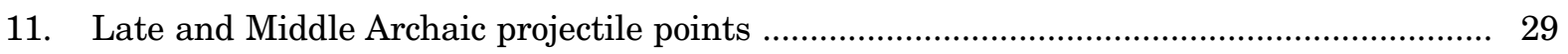

12. Early Archaic and Paleoindian projectile points …........................................................ 30

\section{LIST OF TABLES}

1. Vertical distribution of rocks in burned rock concentration ......................................... 18

2. Size breakdown for flakes in the debitage concentration ............................................... 21

3. Breakdown of debitage concentration by flake type ......................................................... 24

4. Provenience of projectile points ................................................................................ 26

5. Distribution of diagnostic points by time period and site area ......................................... 31

6. Counts of lithic artifacts and temporal diagnostics by unit and level in the western part of the site

7. Average artifact frequencies by level in the western part of the site ................................ 34

8. Inventory of prehistoric artifacts by provenience …........................................................ 45 


\begin{abstract}
From 1984 to 1987, a series of archeological projects was undertaken by the Texas State Department of Highways and Public Transportation (SDHPT, now the Texas Department of Transportation, TxDOT) at site 41TV875 in Travis County, Texas. The work focused on the historic component, representing the late-nineteenth- to early-twentieth-century farmstead of the African American Rubin Hancock family, but many prehistoric artifacts were recovered as well. In 1998, TxDOT contracted with Prewitt and Associates, Inc., to complete the analysis, report production, and curation requirements for the mitigation work on both the prehistoric and historic components. This volume discusses the prehistoric component.

Study of the prehistoric materials had five primary goals. The first was to produce an inventory of the artifacts. The second was to conduct a typological analysis of the projectile points to gain an understanding of the chronology of the site. The third was to couple the chronological information with an examination of the horizontal and vertical distributions of the cultural materials to determine whether components can be isolated. The fourth was to identify those parts of the collection that have the potential to yield important information and hence warrant curation. And the fifth was to analyze the materials from a concentration of lithic debitage to determine if they represent a cache.

Analysis revealed that the site was occupied sporadically beginning at the late end of the Paleoindian period and continuing into the early part of the Late Prehistoric period. Most of the deposits were mixed, but it appears that a reasonably discrete early component may have been present in one part of the site. These early materials have the greatest interpretive potential. Analysis of the materials in the lithic debitage concentration indicates that they are not particularly homogeneous but, instead, they consist of a wide range of flake types and sizes representing various reduction strategies and stages. There is little evidence that the materials were being prepared for further tool manufacture. This concentration can be interpreted best as a discard pile.
\end{abstract}




\section{ACKNOWLEDGMENTS}

Recognition and thanks are due, first and foremost, to the individuals whose efforts brought the information in this report to light. Special thanks go to Nancy Kenmotsu and Al McGraw of the Archeology Studies Program, Environmental Affairs Division, Texas Department of Public Transportation (TxDOT), for their excellent coordination and thoughtful dedication to producing a report that best represents the archeological data of the Rubin Hancock site. Mr. McGraw also reviewed the draft report and provided constructive comments, as did Kevin A. Miller of SWCA, Inc.

Recognition also goes to the State Department of Highways and Public Transportation excavation crew (SDHPT, now TxDOT), which included the following: John W. Clark Jr., Al McGraw, Gregory Hunter, Pat Garrett, Pat Corber, Tim Kibble, James Justice, Benji May, David Klipple, Wayne Young, Chuy Gonzales, James Kaspar, and Randy Tesch.

Members of the staff at Prewitt and Associates involved in this project include Ross C. Fields, Principal Investigator, and E. Frances Gadus, Project Archeologist. Contributions to this report were made by Marie E. Blake, Karl W. Kibler, and Elton R. Prewitt. Ms. Blake, the Historical Archeologist for the Rubin Hancock project, did most of the reevaluation of site records and reconstruction of excavation techniques. She provided the section of this report concerning TxDOT excavation methods, as well as some of the background on the history of the project. Ms. Blake also is the coauthor of the report on the historical component of the Rubin Hancock site. Karl W. Kibler provided the prehistoric background section of this report, as well as insights to the geomorphology of the site. Elton R. Prewitt typed the projectile points and scrutinized all artifact categories for previously unrecognized points and/or point fragments. All other sections of the report were authored by Ms. Gadus.

Thanks also go to the laboratory and office staff of Prewitt and Associates. Karen M. Gardner and Tracie L. Stone organized and prepared the prehistoric materials for curation; they also cataloged a limited number of artifacts from proveniences not previously cataloged. Joan Baker compiled an artifact provenience list from the adjusted original catalog. The graphics were produced by Sandra L. Hannum, and the artifact drawings are by Ellen Atha. This report was edited by Ross C. Fields and Audra L. Pineda and produced by Ms. Pineda. 


\section{INTRODUCTION}

This report presents the results of the reevaluation of the prehistoric components and analysis of materials from the Rubin Hancock site, 41TV875. The site was located on the east bank of Walnut Creek in the northwest section of the City of Austin, Travis County, Texas (Figure 1). The site was the home of Rubin Hancock, an African American farmer who occupied the locale from 1881 to 1916. In 1985, the site was determined eligible for listing in the National Register of Historic Places because of its historic associations. Excavations were undertaken in 1987 (Texas Antiquities Committee Archeology Permit No. 630) by the State Department of Highways and Public Transportation (SDHPT, now the Texas Department of Transportation, TxDOT) to mitigate impacts that would result from the extension of Parmer Lane between RR 620 and FM 1325. This highway extension was to pass through the center of the site. The focus of these mitigative excavations was the historic component, however, as excavations progressed it became clear that the prehistoric component was more extensive than originally thought. A large sample of chipped stone artifacts was recovered, while a burned rock feature and a debitage concentration-originally thought to be a cache-were identified.

Upon completion of the fieldwork at 41TV875, all artifacts, records, photographs, and other forms of documentation were returned to the SDHPT offices. In fall 1992, TxDOT contracted with the Texas Archeological Research Laboratory (TARL), of The University of Texas at Austin to conduct an evaluation of the records and materials from 41TV875. TARL made recommendations on research topics and a budget appropriate for report production that would satisfy the requirements of the Antiquities Permit (Headrick 1993). In late 1998, TxDOT contracted with Prewitt and Associates, Inc., to complete the Rubin Hancock site mitigation by analyzing the materials recovered, producing separate reports for the historic and prehistoric components, and preparing materials for curation. In addition, a curriculum unit plan for 7 th graders was developed, focusing on the historic occupation presented in Blake and Myers's 2000 report summarizing the results of the historic investigations and analysis.
Based on TARL's reevaluation of the site records and the impressions of the excavators, TxDOT concluded that the prehistoric component had a limited capacity to contribute important information. It was thought that the prehistoric materials, representing a long occupation span, were disturbed. Thus, the scope of work for analysis and reporting of the prehistoric component specified that the project was to focus on a concentration of debitage thought to be a flake cache to elicit what information such a cache could provide on the transport of lithics, trade, and mobility. Other prehistoric materials recovered from the site were to be summarized, relying on the original SDHPT inventory as much as possible. Diagnostic items such as projectile points were to be classified typologically; detailed technological, morphological, and metric analyses were not to be performed.

Once analysis of the prehistoric materials commenced, two observations were made. First, the supposed lithic cache did not appear to be a cache in the classic sense. Second, a buried, relatively unmixed early component was found to be present at the site. Thus, in consultation with TxDOT, the focus of the project was modified to consider and present this new information. As a result, the analysis of the supposed cache is de-emphasized in this report, while information on the distribution of materials, especially diagnostic projectile points, has been added to recreate the occupational history of the site. In addition, contextual information is presented, including a reevaluation of site stratigraphy and a description of a burned rock feature. The distributional and contextual information is key to identifying parts of the collection that have future research potential. It is this potential that serves as the basis for the recommendations concerning the curation of prehistoric materials from the site. These recommendations are presented after the summary of findings.

\section{ENVIRONMENTAL BACKGROUND}

The Rubin Hancock site was situated 720$725 \mathrm{ft}$ above mean sea level on an interfluve side slope immediately east of the channel of Walnut Creek (see Figure 1). Creek flow in the vicinity of the site is mapped as intermittent until it is joined by two tributaries $1.5 \mathrm{~km}$ 
downstream. The creek continues for another $19.5 \mathrm{~km}$ south-southeast of the site before it joins the Colorado River within the City of Austin. Walnut Creek cuts the hard limestone of the Lower Cretaceous Fredericksburg Group immediately north of the site, while at and downstream from the site, it crosses the Upper Cretaceous Austin Chalk, eventually encountering the calcareous clays of the Upper Cretaceous Taylor Group (Bureau of Economic Geology 1974). Thus, the site is situated where the Fredericksburg Group meets the Austin Chalk within the Balcones Fault Zone.

North and west of the site, the Fredericksburg Group, which includes Comanche Peak Limestone and chert-rich Edwards Limestone, makes up the eastern edge of the Jollyville Plateau. This plateau has been considered both the northern extension of the Edwards Plateau (Garner and Young 1976:5-6) and the southern end of the Lampasas Cut Plain (Johnson 1931:124-125). The Jollyville Plateau is a mature limestone upland that lacks the highly dissected nature of the Edwards Plateau "hill country" to the south and west. East and southeast of the site, the Jollyville Plateau gives way to the Rolling Prairie, which follows the Austin Chalk and Balcones Fault Zone in a band northeast to southwest. This prairie is moderately dissected, with slopes generally less than 5 percent (Garner and Young 1976:5). East of the Rolling Prairie and beyond the immediate vicinity of the site is the Blackland Prairie, which is underlain by calcareous clays of the Taylor Group. Both prairies are bisected by the Pleistocene and Holocene terrace and floodplain deposits of the Colorado River (Garner and Young 1976:5-6).

Soils associated with the Austin Chalk are dark brown to grayish brown calcareous silty loam and clay loam. Within the area of 41TV875, the soils are mapped as Austin silty clay and Stephen silty clay loam (Werchan et al. 1974). Austin silty clay is found on ridge tops and slopes and has an A horizon averaging 8-20 inches thick. Soil colors range from grayish brown, very dark grayish brown, to dark brown based on moisture content. The B horizon can be 8-32 inches thick before a mixture of weathered chalk and brown silty clay loam of the $\mathrm{C}$ horizon appear. Colors of the $\mathrm{B}$ horizon are grayish brown, pale brown, brown, light yellowish brown, or light brownish gray
(Werchan et al. 1974:12-13). Calcium carbonate concretions are present in the B horizon. Stephen silty clay loam occurs on ridge saddles and side slopes. The A horizon is less than 20 inches thick before broken platy chalk appears. Soil color ranges from very dark grayish brown to dark brown with bits of chalk increasing in size with depth (Werchan et al. 1974:38).

The location of 41TV875, at the edges of the Jollyville Plateau and the Rolling Prairie, also places it at the juncture of two biotic provincesthe Balconian and Texan-as defined by Blair (1950). The modern climate of the Balconian province decreases in rainfall from east to west. Thus, the eastern edge (where 41 TV875 is located) is classified as dry subhumid mesothermal with an average annual potential evapotranspiration rate of 39.27 to 44.88 inches (Blair 1950:113). Vegetation in the eastern part of the province may be considered oaksavannah, as it is composed of grassland interspersed with thickets of live, scrub, and blackjack oaks (Garner and Young 1976:Plate VI). In contrast, the Texan biotic zone has been classified as subhumid with a moisture index of as much as 20 percent. However, vegetation on the Rolling Prairie-composed of a live oakgrassland assemblage-does not differ greatly from that of the Jollyville Plateau. Rather, both vegetation assemblages contrast more sharply with the westerly parts of the Texan province, which include the lush tall grasses of the Blackland Prairie and the hardwood forests of cottonwood, sycamore, willow, pecan, ash, hackberry, and bois d'arc trees found in the bottomlands that follow the course of the Colorado River.

Blair (1950:113-114) reports that over 57 species of mammals are known to exist within the Balconian province but that none are restricted to the province; all are found in provinces to the south, west, or east. Mammals with eastern affinities include Didelphis virginiana, Pipistrellus subflavus, Sciurus niger, and Sylvilagus floridanus. Population densities of these mammals are thought to remain low within the Balconian province, since it is suspected that they are at their ecological limits. Other animals found in the Balconian province include 16 species of lizards, 36 species of snakes, and 15 species of frogs. Within the Texan province, 49 species of mammals are known. Common grassland species of mammals include 
Citellus tridecemlincatus, Peromyscus maniculatus, Perognathus hispidus, and Lepus californicus. The last two of these species also are found in the Balconian province. The Texan province also is home to 16 species of lizards ( 9 of which also are found in the eastern forests), 39 species of snakes, and 18 species of frogs.

At the time that 41 TV875 was excavated, the site area was described as supporting a cover of both large and small live oaks along with a mix of junipers, hackberries, small shrubs, and a variety of short grasses and forbs (Clark 1985a:2). It was observed that hackberry trees tended to form alignments along former fence lines, an indication of their volunteer nature. The area surrounding the site to the north, south, and west was wooded, and a formerly plowed field lay to the east (Clark 1985a:2).

\section{ARCHEOLOGICAL BACKGROUND}

The prehistoric cultural sequence of the Rubin Hancock site can be based on the central Texas sequence. This sequence has been divided into the three broad periods-Paleoindian, Archaic, and Late Prehistoric-although the terms Neoarchaic (Prewitt 1981, 1985) and PostArchaic (Johnson and Goode 1994) have been used at times in place of the term Late Prehistoric. These broad periods have been expanded by researchers into a culturalhistorical framework, which incorporates morediscrete temporal and technological units (phases) that have been delineated and defined by Prewitt (1981, 1985) (Figure 2). Recently, Johnson and Goode (1994) and Collins (1995) have presented revised cultural chronologies of the region and at the same time discontinued use of the term "phase" to describe each culturalhistorical unit. They have opted for named intervals or patterns based on diagnostic projectile point styles and associated radiocarbon assays (e.g., Martindale-Uvalde interval) within each period or subperiod (see Figure 2). Although all of these sequences chronologically group and order archeological assemblagesprimarily projectile point styles-and site components, a common criticism is that these temporal-stylistic units/intervals/patterns do not specifically address cultural processes, such as the adaptive strategies utilized by certain (ethnic) groups in a particular territory at a certain period of time (Black 1989:35; Collins 1995:362; Ellis et al. 1995). Despite this criticism, the following summary of the three periods of central Texas prehistory is presented based mainly on Collins's (1995) sequence.

\section{Paleoindian}

The Paleoindian period (11,500-8800 B.P.) represents the earliest known cultural manifestation in North America. Sites and isolated artifacts from this period are fairly common across central Texas. This period often is described as having been characterized by small but highly mobile bands of foragers who were specialized hunters of Pleistocene megafauna. However, a more accurate view of Paleoindian lifeways probably includes the utilization of a much wider array of resources. Recent investigations at the Wilson-Leonard site (41WM235) support this view and have challenged the fundamental defining criterion of the period-that of artifacts in association with late Pleistocene megafauna (Masson and Collins 1995).

Environmental conditions during the Paleoindian period provided early inhabitants with a much different array of resources than presently available. Nordt et al. (1994) view this period as a transition between cooler and moister late Pleistocene conditions and warmer and drier Holocene conditions. They estimate that grasses tolerant of more-arid conditions steadily increased throughout this period. Toomey et al. (1993) also see this time as a period of transition, with summer temperatures increasing rapidly but still $2-3^{\circ} \mathrm{C}$ below modern values. Toomey et al. (1993) suggest that effective moisture decreased around 14,000 B.P. and then increased, peaking at ca. 10,500 B.P.

Collins (1995) divides the Paleoindian period into early and late subperiods. The early subperiod consists of two projectile point style intervals, Clovis and Folsom. Clovis chipped stone artifact assemblages, including the diagnostic fluted lanceolate Clovis point, were produced by bifacial, flake, and prismatic-blade techniques on high-quality and oftentimes exotic lithic materials. Along with chipped stone artifacts, Clovis assemblages include engraved stones, bone and ivory points, stone bolas, and ochre (Collins 1995:381; Collins et al. 1992). Analyses of Clovis artifacts and site types suggest that Clovis people were well-adapted, 


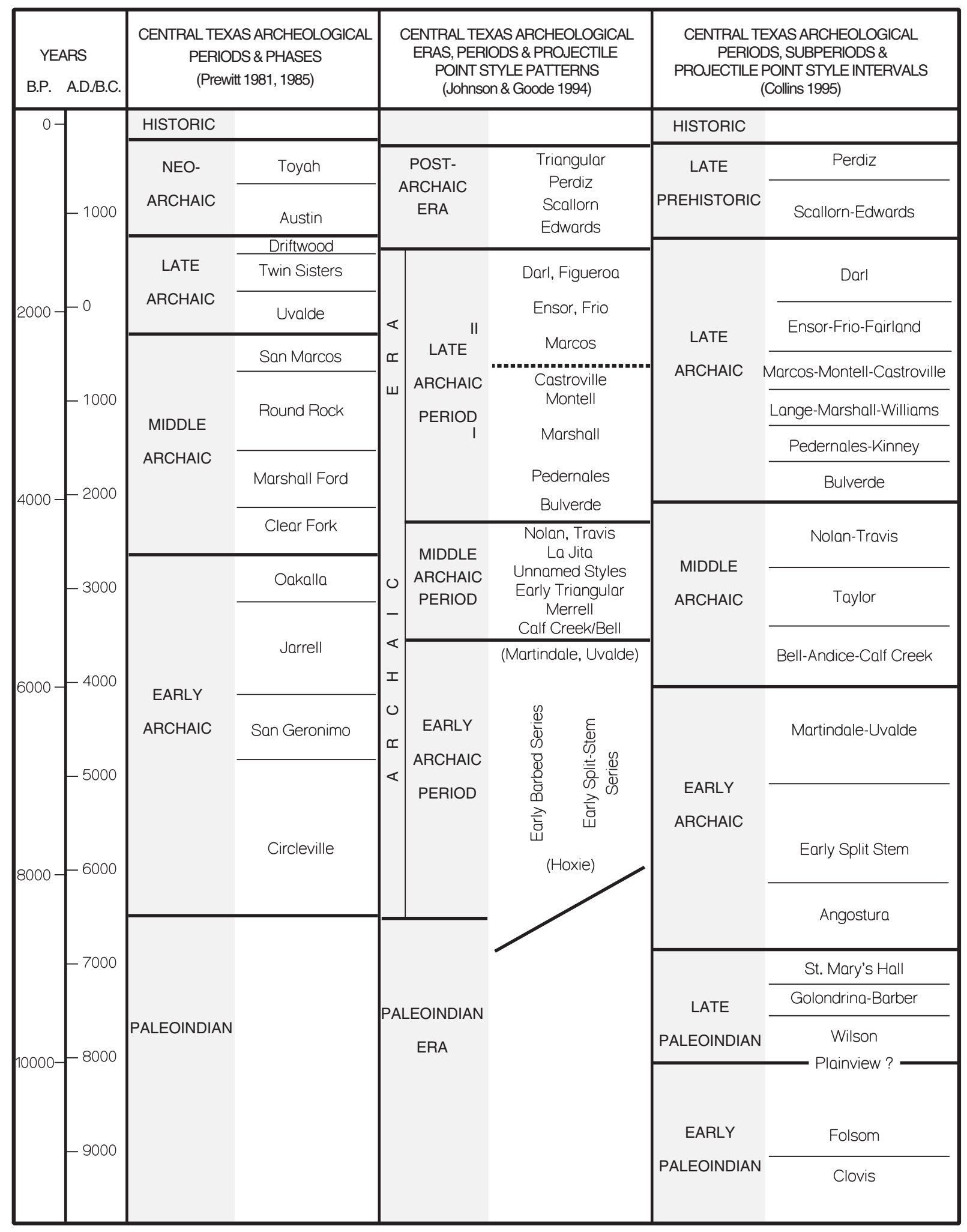

Figure 2. Prehistoric cultural sequences of Prewitt (1981, 1985), Johnson and Goode (1994), and Collins (1995). 
generalized hunter-gatherers. They had the technology to hunt larger game but did not solely rely on it. In contrast, Folsom tool kits consisting of fluted Folsom points, thin unfluted (Midland) points, large thin bifaces, and end scrapers are more indicative of specialized hunting, particularly of bison (Collins 1995:382).

Spanning the end of the early and initial Late Paleoindian subperiods are several projectile point styles for which temporal, technological, or cultural significance is unclear. Included are Plainview points, a type name typically assigned to any unfluted lanceolate dart point. Collins (1995:382) has noted that central Texas Plainview points do not parallel those from the Plainview type site in thinness and flaking technology. Also problematic are the chronological position and cultural significance of Dalton and San Patrice dart points. The succeeding Late Paleoindian subperiod includes three projectile point style intervals spanning the period from ca. 10,000 to 8800 B.P.: Wilson, Golondrina-Barber, and St. Mary's Hall. Components and artifact and feature assemblages of these three intervals appear to be Archaic-like in nature and in many ways may represent a transition between the Early Paleoindian and succeeding Archaic periods (Collins 1995:382).

\section{Archaic}

The Archaic period (8800 to $1300-1200$ B.P.) generally is believed to represent a shift toward the hunting and gathering of a wider array of animal and plant resources and a decrease in group mobility (Willey and Phillips 1958:107108), although such changes probably were well under way by the beginning of the Archaic. Throughout the ca. 7,600-year-long period, major climatic changes probably presented Archaic populations with varying subsistence challenges. The Archaic often is divided into Early, Middle, and Late Archaic periods (Black 1989; Collins 1995; Story 1985:28-29). Each subperiod includes several temporal-stylistic units or intervals based on diagnostic projectile point styles and associated radiocarbon assays (Collins 1995).

Early Archaic (8800-6000 B.P.) sites are small, and their tool assemblages are diverse (Weir 1976:115-122), suggesting that populations were small and highly mobile (Prewitt
1985:217). It has been noted that Early Archaic sites are concentrated along the eastern and southern margins of the Edwards Plateau (Johnson and Goode 1994; McKinney 1981). This distribution may be indicative of climatic conditions at the time, as these environments have many reliable water sources and a diverse subsistence base. Microfaunal records and sedimentary evidence from stream valleys and along the eastern Edwards Plateau depict a climatic regime in flux, from mesic conditions during the beginning of the Early Archaic, to extremely xeric conditions in the middle part of the period, and back to milder conditions at the end of the period (Collins et al. 1990; Toomey et al. 1993). Three projectile point style intervals are recognized: Angostura; Early Split Stem, including Gower and Jetta; and MartindaleUvalde (see Figure 2). Manos, metates, hammerstones, Clear Fork and Guadalupe bifaces, and a variety of other bifacial and unifacial tools are common to all three intervals. The construction and use of rock hearths and ovens reflect a specialized subsistence strategy (possible exploitation of roots and tubers) during the Early Archaic. These burned rock features most likely represent the technological predecessors of the larger burned rock middens extensively used later during the Archaic period (Collins 1995:383).

During the Middle Archaic period (60004000 B.P.), the number and distribution of sites, as well as site size, increased due to probable rises in population densities (Prewitt 1981:73; Weir 1976:124, 135). Macrobands may have formed at least seasonally, or an increased number of small groups may have utilized the same sites for longer periods of time (Weir 1976:130-131). A greater reliance on plant foods is suggested by the presence of burned rock middens toward the end of the Middle Archaic, although tool kits still imply a strong reliance on hunting (Prewitt 1985:222-226). Three projectile point style intervals make up the Middle Archaic: Bell-Andice-Calf Creek, Taylor, and Nolan-Travis. The Bell-Andice-Calf Creek and Taylor intervals reflect a shift in lithic technology from the preceding MartindaleUvalde interval (Collins 1995:384). Johnson and Goode (1994:25) suggest that the Bell-AndiceCalf Creek interval represents an influx of bison hunting groups from the Eastern Woodland margins into the central Texas region during a 
slightly more-mesic period. Bison disappeared as more-xeric conditions returned during the later Nolan-Travis interval. This style change represents another shift in lithic technology (Collins 1995:384; Johnson and Goode 1994:27). Prewitt (personal communication 1996) postulates that the production and morphology of Travis and Nolan points are similar to projectile points from the Lower Pecos region. Characteristics such as beveled stems and overall morphology may have originated in the Lower Pecos, since their presence in this area predates their appearance in central Texas. The accompanying change to more-xeric conditions bears witness to the construction and use of burned rock middens. Johnson and Goode (1994:26) believe that dry conditions promoted the spread of xerophytic plants, such as yucca and sotol, and that these plants were collected and cooked in large rock ovens by late Middle Archaic peoples.

Both Collins (1995) and Johnson and Goode (1994) recognize a period of extreme aridity in central Texas during the Archaic period and postulate that the construction and use of burned rock middens were responses to these xeric conditions. However, Collins (1995), as well as Nordt et al. (1994) and Toomey et al. (1993), views these xeric conditions as the culmination of a continual decrease in effective moisture since the end of the Pleistocene. Johnson and Goode (1994) disagree with this postulation. In addition, Johnson and Goode (1994) believe a period of aridity - their Edwards interval-occurred slightly later, ca. 42502550 B.P., compared to Collins's (1995) much longer Altithermal climate at 8500-6800 and 5500-3000 B.P. (also cf. Nordt et al. [1994] and Toomey et al. [1993]).

During the succeeding Late Archaic period (4000 to $1300-1200$ B.P.), populations continued to increase (Prewitt 1985:217). The establishment of large cemeteries along drainages suggests strong territorial ties by certain groups (Story 1985:40). Xeric conditions continued but became more mesic ca. 3500-2500 B.P. The Late Archaic period consists of six projectile point style intervals (Collins 1995:376): Bulverde, PedernalesKinney, Lange-Marshall-Williams, MarcosMontell-Castroville, Ensor-Frio-Fairland, and Darl. Johnson and Goode (1994:29-35) divide the Late Archaic into two parts-Late Archaic I and Late Archaic II-based on increased population densities and evidence of Eastern Woodland ceremonial rituals and religious ideological influences. Middle Archaic subsistence technology, including the use of burned rock middens, continued into the Late Archaic period. Collins (1995:384) states that during the Pedernales-Kinney interval the construction and use of burned rock middens reached its zenith; their use declined during the latter half of the Late Archaic. However, mounting chronological data suggest that midden formation and use culminated much later, during the Ensor-Frio-Fairland and Darl intervals, and that this high level of use continued into the early Late Prehistoric period (Black et al. 1997; Kleinbach et al. 1995:795). A picture of prevalent burned rock midden use in the eastern part of the central Texas region after 2000 B.P. is gradually becoming clear. This scenario parallels the widely recognized occurrence of post-2000 B.P. middens in the western reaches of the Edwards Plateau (see Goode 1991). The use of burned rock middens appears to have been a major part of the subsistence strategy as a decrease in the importance of hunting-inferred from the low ratio of projectile points to other tools in site assemblages-may have occurred (Prewitt 1981:74).

\section{Late Prehistoric}

The Late Prehistoric period (1300-1200 to 300 B.P.) is marked by the introduction of the bow and arrow and later ceramics into the region, probably from the north (Prewitt 1985:228). Population densities dropped considerably from their Late Archaic peak (Prewitt 1985:217). Subsistence strategies did not differ greatly from the preceding period, although bison became an important economic resource during the latter part of the Late Prehistoric period (Prewitt 1981:74). The use of burned rock middens for plant food processing continued throughout the Late Prehistoric period (Black et al. 1997; Goode 1991; Kleinbach et al. 1995:795). Horticulture came into play very late in the region, but it was of minor importance to the overall subsistence strategy (Collins 1995:385).

In central Texas the Late Prehistoric period generally is associated with the Austin and 
Toyah phases (Jelks 1962; Prewitt 1981:82-84); however, both phases have a much wider application. The Austin and Toyah phase horizon markers, Scallorn-Edwards and Perdiz arrow points, are distributed across most of the state. The introduction of Scallorn and Edwards arrow points into central Texas often was marked by evidence of violence and conflict, as many excavated burials from this period indicate that these points were the cause of death (Prewitt 1981:83). Subsistence strategies and technologies (other than arrow points) did not change much from the preceding Late Archaic. This continuity is recognized by Prewitt's (1981) use of the term "Neoarchaic."

Around 1000-750 B.P., slightly more-xeric climatic conditions returned to the region and bison returned in large numbers (Huebner 1991; Toomey et al. 1993). Utilizing this vast resource were Toyah peoples equipped with Perdiz-tipped arrows, end scrapers, four-beveled-edge knives, and plain bone-tempered ceramics. The technology and subsistence strategies of this phase represent a completely different tradition than the preceding Austin phase. Collins (1995:388) states that burned rock middens fell out of use as bison hunting and group mobility obtained a level of importance not witnessed since Folsom times. While the importance of bison hunting and high group mobility hardly can be disputed, the cessation of burned rock midden use during the Toyah phase is tenuous. A recent examination of Toyah-age radiocarbon assays and assemblages by Black et al. (1997) suggests that their association with burned rock middens represents more than a thin veneer capping Archaic-age features. Black et al. (1997) claim that burned rock midden use, while not as prevalent as in preceding periods, did play a role in the adaptive strategies of Toyah peoples.

\section{PREVIOUS INVESTIGATIONS}

In August 1984, personnel from SDHPT surveyed the proposed route for the Parmer Lane extension. Eight sites, seven of which had been previously recorded, were found in or near the right of way. These sites included 41TV113, a small burned rock midden outside the right of way; 41TV323, a lithic resource procurement area; 41TV856, a prehistoric lithic scatter and historic housesite outside the right of way; 41TV857, a prehistoric lithic scatter and disturbed historic housesite; 41WM590 a lithic scatter and 1920s historic housesite; 41WM494, a disturbed burned rock midden site; and 41WM585, a diffuse prehistoric lithic scatter. The only new site recorded was 41 TV875. At that time, 41 TV875 was described as a pre- 1937 historic housesite. Apparently, the prehistoric component was not discovered by the survey, as the site form mentions a lack of prehistoric materials. Site 41 TV875 was the only one out of the eight that was recommended for further work because of the undisturbed condition of its historic component.

Testing of site 41TV875 was conducted by SDHPT staff members in February 1985 (Clark 1985a). Site boundaries were established by identifying and recording a variety of surface features. These features included a hand-dug stone-lined well, a galvanized metal pipe for a later drilled well, and an animal pen constructed of juniper posts, cut nails, and barbed wire. Also, in the northwest area of the site two segments of a low, dry-laid stone wall were observed. It was hypothesized that this wall represented the lower portion of a post and barbed wire fence. Finally, an abandoned roadbed was observed at the north edge the site (Clark 1985a:4). Scattered surface artifacts were noted, including numerous tin cans, sheet metal, barbed wire, barrel hoops, and wire, as well as sherds of glass and ceramic. Only the cut nails in the fence post were considered to be temporally diagnostic, suggestive of pre-1890 construction (Clark 1985a:4). No mention is made in the testing report of prehistoric materials associated with the artifact scatter.

The testing effort continued with a metal detector survey designed to locate concentrations of buried artifacts/metal. A grid of $20-\mathrm{ft}$ squares, limited to the boundaries of the site, was staked and linked to the proposed road center line. Several areas of surface and subsurface metal were detected and plotted on a topographic map. Based on the results of the metal detector survey, it was determined that the area of intensive occupation measured $140 \times 100 \mathrm{ft}$ and contained both surface and subsurface historic features. It also was noted that no concentrations of metal were detected in the area believed to have contained the house, as indicated by the presence of alignments of stones visible on the surface (Clark 1985a:7).

Archival research conducted in conjunction 
with the testing fieldwork revealed that the site had been occupied by an African American family from ca. 1870 to 1920 , and that Rubin Hancock was in residence on the property in 1881. It was believed that research on the site could fill an important data gap. Archeological work had been performed at ante-bellum slave and free-Black sites, as well as post-bellum Anglo American sites, but little work had been done to address post-bellum African American occupations (Clark 1985a:6, 8). Consequently, at the end of testing it was concluded that 41TV875 met the necessary requirements for inclusion in the National Register of Historic Places under Criterion D (Clark 1985a:6, 9). Based on the testing results and subsequent recommendations, a mitigation proposal was prepared for 41TV875.

The research design for the mitigation of 41TV875 (Clark 1985b) outlined 12 objectives for the work and focused exclusively on the historic component; no mention is made of the presence of a prehistoric component. However, an interoffice memo (dated April 17, 1985) from John W. Clark Jr. to Frank A. Weir concerning Texas Historical Commission comments on the research design indicates that SDHPT personnel thought the prehistoric component was ephemeral and disturbed.

The objectives of the research design encompassed historic data deemed recoverable from both archival and archeological sources. Five of the objectives were discussed in greater length, and specific methodologies were offered. All objectives were then distilled into three common goals for the research. These goals were to "develop information on (1) the level of integration of the inhabitants of the area into national and local markets; (2) material manifestations of ethnicity and social status; and (3) horizontal patterning of artifacts and the functional pattern of artifacts as a manifestation of culture" (Clark 1985b:7). Also included in the research design was a brief description of the personnel, project duration, curation, and reporting plan for the excavation (Clark 1985b:8, 9).

\section{FIELD AND LAB METHODS}

Mitigative excavations at 41TV875 were performed between 20 July 1987 and 9 October 1987 under the direction of John W. Clark Jr. and under the general supervision of Dr. Frank A. Weir, Director of Archaeological Studies for SDHPT. Al McGraw of SDHPT directed the first week of work. During that time, the grid system for the excavation was established (Figure 3). All measurements and coordinates were made in the English/standard system. The center line stations for the Parmer Lane right of way were utilized as the baseline. Specifically, stations 586 through 589 were used to designate east-west measurements on the grid. Distances east of a center line station were designated in 5 -ft increments. For example, E587+20 would indicate a location $20 \mathrm{ft}$ east of center line station 587. The north-south axis was designated with a northing coordinate, with the N100 line along the right of way center line. Northing coordinates ranged from $\mathrm{N} 0$ at the southern end of the site to N200 at the north end, all falling within the Parmer Lane right of way corridor. Each excavation unit was assigned a coordinate designation with reference to its southeast corner.

Clark took over direction of the fieldwork on 3 August 1987. He maintained a log for each day of work at the site. All units were excavated by hand with a shovel or trowel when deemed necessary. All sediments were screened through $1 / 4$-inch-mesh hardware cloth. Due to the extreme thinness of the deposits in the eastern portion of the site where the historic component was primarily located, no vertical levels were used. Most of those units yielded only one level of deposits before limestone bedrock was encountered, usually at an average depth of 0.2 to $0.3 \mathrm{ft}$ and generally no more than $0.5 \mathrm{ft}$. In the western portion of the site where most of the prehistoric materials were encountered, the deposits were radically deeper, up to $6 \mathrm{ft}$ or more in some places. In that area, levels usually were excavated in 0.5 -ft. increments.

As excavation progressed, each level of each unit was assigned a unique bag number. The bag numbers were assigned in numerical order on an as-needed basis and did not necessarily correspond with the sequence of levels within a unit. For example, Level 1 of Unit E588+40/ N100 was started on August 11 and assigned bag number 44 . Further work was not carried out in that unit until October 2, so Level 2 was assigned bag number 175 . Assignments were recorded on a SDHPT bag log form which included information on bag number, unit 


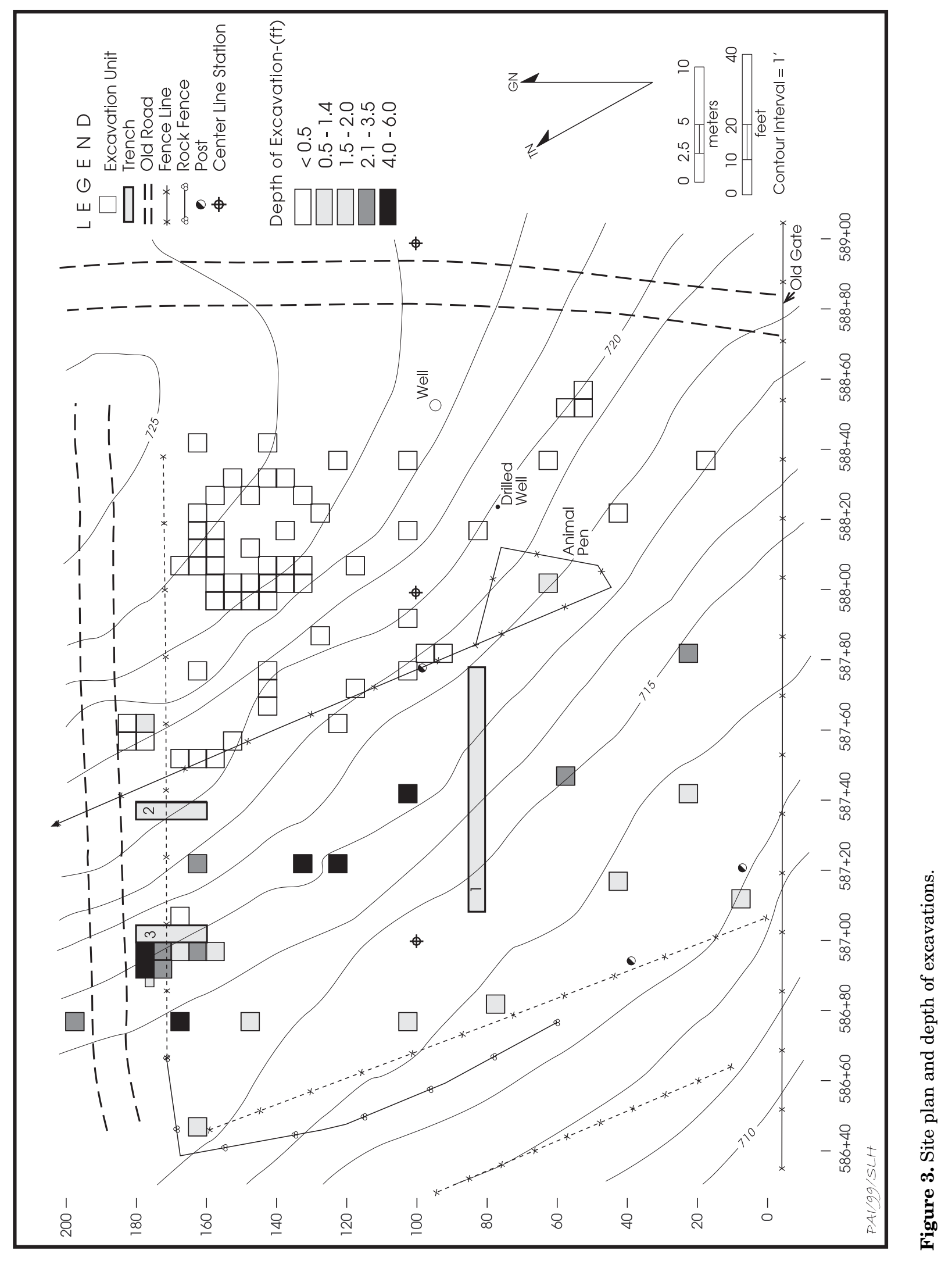


coordinates, level, depth, description, and date.

Each excavation unit and its corresponding levels were documented on SDHPT record forms. Each form indicated the unit designation, the corresponding bag number(s), dimensions of the unit, the recorder's name, and the excavation date. In cases of shallow units with one level, a description of the matrix was given. In cases of deeper units with multiple levels, changes in soil color and inclusions were noted by level on one record form. Individual level forms were not utilized. The recovery of prehistoric tools (usually identified projectile points) also was often noted by level, and outlines were sometimes drawn on the record form. Presence or absence of artifact types such as historic materials or lithics was noted in deeper units. When encountered, the presence of gravels or bedrock at the base of a unit was indicated. Horizontal location relative to fence lines, the well, or other surface features was noted for units when appropriate. Units in the historic area of the site were identified relative to the site layout, such as "east of the house." The presence of historic features, such as the chimney hearth, within a unit was noted. Occasionally, historic features were sketched on the record forms. Separate feature forms or feature numbers were not utilized. Elevations were not taken on a regular basis, but some were indicated on the forms. Elevations were recorded more systematically during the first week of work and during work on the prehistoric component late in the project.

Three Gradall trenches were excavated during the five weeks of excavations. Trench 1 was $70 \mathrm{ft}$ long, and Trenches 2 and 3 were $20 \mathrm{ft}$ long. Trench 1 was excavated to cross section what appeared to be a filled stream channel, and the two shorter trenches were dug to try to locate a possible privy. No indication of a privy feature was found, but one of the shorter trenches (Trench 3) encountered a burned rock feature. Profiles were drawn of Trenches 1 and 3. Sediments from the trenches were not screened, and only four artifacts were collected from the backdirt of Trench 3 . The trenches were backfilled by the time exploration of the burned rock feature began in units to the west of Trench 3.

Besides sketches included on record forms, a variety of maps, plans, and profiles were drawn. A composite site map was drawn which included all subsurface excavations, historic surface features, modern surface features, some subsurface features, vegetation (identified to species), topography, site grid, and the interpreted location of the house. Fifteen plans and profiles were drawn of rock concentrations uncovered at the site. One specifically depicts the chimney hearth and a portion of the foundation.

A plan view and cross section were drawn of the hand-dug well at 41TV875. Special efforts were made to explore the well and its contents. The well was open and had been used for refuse disposal during the twentieth century. This practice probably began with the advent of the drilled well as a primary source of water. No controlled excavation was undertaken, but an attempt was made to sample the deposits within the well. Fourteen boxes of modern debris were retrieved from the well and returned to the SDHPT lab. The intent was to dig beyond the modern debris and perhaps encounter historic deposits. However, at a depth of ca. $23 \mathrm{ft}$ below the surface, a void approximately $5 \mathrm{ft}$ deep was encountered. Eventually, the effort was abandoned due to the threat of structural collapse within the well. Historic deposits never were reached.

In addition to drawings, many photographs were taken. Some rolls have accompanying photo logs, whereas most do not. Four types of photography were used: $35-\mathrm{mm}$ color slides (122 frames); $35-\mathrm{m}$ black-and-white prints ( 80 frames); 11/2x 2 -inch black-and-white prints (30 frames); and $2 \frac{1}{4} \times 2^{1 / 4}$-inch black-and-white prints (69 frames). Most aspects of the site were recorded photographically, including surface and subsurface features, profiles, and the general site area.

The artifacts recovered were packaged and sent to the lab at SDHPT for washing and cataloging. In the lab, bag numbers were converted into lot numbers. For example, what was bag number 44 in the field became lot number 44 in the lab and in the specimen inventory. During lab processing, prehistoric and historic materials were separated, and then each class of material was sorted into smaller analytical units and identified. For example, prehistoric materials were sorted into categories such as identified projectile points, bifaces, primary flakes, etc. Historic materials were sorted into categories such as ceramics by ware type, glass by color, different types of nails, and 
so on. In general, all materials were sorted into fairly specific categories. A specimen inventory was prepared which included lot number, number of specimens, description, location (horizontal and vertical), and associated references. Many illustrations of both prehistoric and historic artifacts were included in the specimen inventory. A percentage of the artifacts were labeled with site and lot numbers. Artifacts were bagged according to lot number in the same categories listed in the specimen inventory. The bags were labeled on the exterior in indelible black ink with site number, lot number, artifact count, and description.

\section{SUMMARY OF WORK ACCOMPLISHED}

The excavations were done in stages. As the prehistoric component was found to be more substantial than originally thought, additional efforts were required to ensure its investigation. When completed, 87 units were excavated, all of which measured $5 \times 5 \mathrm{ft}$, with the exception of one $2.5 \times 2.5$-ft unit.

The efforts of a crew of 5-6 persons in the first five weeks of the project focused on the historic component. As this excavation proceeded, it became obvious that a significant amount of prehistoric material was present. As explained below, the deposits in the eastern part of the site-the location of the Rubin Hancock house-were shallow with no more than one level excavated before bedrock was encountered. The house area produced a mix of both historic and prehistoric materials. However, deeper units in the western part of the site, which had been the area of Hancock's garden, produced prehistoric materials well below the level of the historic artifacts. Also, Gradall Trench 3, opened in the western part of the site to look for the privy location, encountered a burned rock concentration. At the end of the first five weeks, 79 of the units (representing 144 levels) and three backhoe trenches had been excavated. This phase of work resulted in the documentation of a variety of historic surface/subsurface features and recovered significant amounts of prehistoric artifacts.

The second phase of work, initiated on September 9 and lasting till October 7, was undertaken at the request of the Texas Historical Commission to explore the prehistoric component. Twelve work days were spent to open eight additional units. First, two $5 \times 5-\mathrm{ft}$ units were opened west of Gradall Trench 3 to explore the burned rocks observed in the trench wall. As it became clear that the rocks formed a large concentration, six more units were opened west and southwest of the trench to form a block of seven $5 \times 5$ - $\mathrm{ft}$ units and one $2.5 \times 2.5$-ft unit. The last two units excavated contained a feature interpreted as a lithic cache. Most of the units in the block were terminated at the base of the burned rock concentration, which was $2.0-2.5 \mathrm{ft}$ below the surface. Only two units in the block were excavated to a thick gravel deposit at a depth of $4.5 \mathrm{ft}$. In all, forty-three 0.5 -ft-thick levels were excavated from the block. However, materials from the levels above the burned rock concentration in three units were not separated, and materials from levels above the "lithic cache" in the $2.5 \times 2.5$-ft unit were not retained. Other work completed during this final period included collection of five burned rock samples, seven matrix samples from a burned rock cluster, and soil samples from four soil zones from the north wall of the block.

\section{ANALYSIS AND CURATION METHODS}

This project called for a thorough review of field notes and all other pertinent records to reconstruct, in as much detail as possible, what was done during the excavations and what was found. This reconstruction provides the basis for interpreting features and addressing questions concerning site layout and distributional patterning. Much of the records review was completed as part of the analysis of the historic materials (see Blake and Myers 2000). This effort produced a verified provenience list that coordinates unit, artifact bag/lot number, level, and depth in feet below surface with the original artifact inventory. Utilization of this list during both the historic and prehistoric analyses prevented duplication of effort and provided for continuity between the historic and prehistoric reports.

Study of the prehistoric materials had five primary goals. The first was to produce an inventory of the artifacts recovered using the catalog prepared by SDHPT after completion of the fieldwork and limited reclassification of specific artifact groups. The second was to conduct a typological analysis of the projectile points to gain a complete understanding of the 
chronology of the site given the lack of radiocarbon dates. The third was to couple the chronological information with an examination of the horizontal and vertical distributions of cultural materials to determine whether components could be isolated. The fourth was to identify those parts of the collection with the potential to yield important information and, hence, warrant curation. The fifth goal was to analyze the materials from the "cache" to determine if they, in fact, represent a cache or simply a concentration of discarded lithic debris.

Six of the provenienced lots, which included the "cache" materials, had not been cataloged by SDHPT personnel. These materials were classified using the artifact categories established for the original catalog but were recorded in a separate catalog addendum, as were the reclassified projectile points and point fragments. In this way, the original catalog remains unaltered. A compilation of materials by provenience derived from both the original catalog and the addendum appears as an Appendix to this report. Prehistoric artifacts selected for curation were rebagged and boxed, while materials from the supposed cache, along with the projectile points and point fragments, were washed and labeled with site and lot number. Site photographic slides and black-andwhite prints also were labeled with site number, unique catalog number, and description; they then were placed in archival quality sleeves. Duplicate copies of all original records were made on archival quality paper.

Analysis of the materials from the "cache" began with separating chipped stones from unmodified rocks. Both unmodified rocks and chipped stone materials were classed by raw material type and sized using maximum dimension based on a 1-cm incremental concentric ring scale. Since almost all the chipped stone materials appeared to be flakes, a twofold analysis approach was initiated using an attribute-based analysis and a general descriptor of flake type. This was seen as the best way to characterize basic technological features of the chipped stone materials. In addition, the presence of secondary techno-logical features, such as edge modification and/or heating, was noted where they occurred.

Flake attributes include completeness, dorsal cortex percentage, chunk cortex presence/ absence, number of platform facets, and platform grinding. Flake completeness was described as complete, proximal, chip, or chunk. Complete flakes have striking platforms and hinged or feathered terminations, while proximal fragments are broken flakes that retain striking platforms. Chips are flake fragments lacking a bulb of percussion/striking platform. Angular shatter is classed as chunks. Dorsal cortex percentage was recorded for all flakes in four percentage increments $(0-25,26-$ $50,51-75$, and 76-100), while chunk cortex was recorded as present or absent. Platform grinding was recorded as present when the edge formed by a flake's dorsal surface and the platform was visually confirmed under low-power magnification as rounded. Counting of striking platform facets also was done under low-power magnification. Facets that could be attributed to platform crushing during flake removal were not counted. All the variables also contained a category labeled "indeterminate," since thick calcium carbonate rinds often obscured flake surfaces making attribute determinations questionable.

Flake type was recorded for complete flakes, proximal flakes, and chips; it incorporates flake shape with other attributes to provide a comprehensive picture of the stage of reduction through which a flake was generated. Three flake types and an indeterminate category were used. Type 1 includes flake shapes ranging from bladelike to rounded half moon, with a straight longitudinal cross section and a large bulb of percussion. Striking platforms on these flakes generally are not ground or faceted, and the flakes may range from entirely corticate to partially decorticate. These flakes are considered core preparation flakes generated with the use of hard hammer reduction techniques. Type 2 flakes are broad with parallel edges, are trapezoidal, or have an expanding triangular shape. They are partially to completely decorticate. They have minimal to medium longitudinal curvature, moderate to large multiple dorsal flake scar ridges, and a pronounced bulb of percussion. The striking platform generally is a single facet and not ground, although some instances of grinding and multiple facets do occur. These flakes are considered secondary core reduction flakes. Type 3 flakes are similar in shape to Type 2 flakes and also have minimal to medium longitudinal curvature. However, Type 3 flakes 
have a minimal bulb of percussion with a small multifaceted and ground striking platform. These are tertiary flakes that exhibit a large number of dorsal flake scars with shallow ridges. As such, they may be considered latestage core reduction flakes and/or bifacial thinning flakes. The Type 4 indeterminate flakes do not fit any of the three types described above due to insufficient diagnostic traits.

\section{REEVALUATION OF THE PREHISTORIC COMPONENTS}

\section{Site Stratigraphy}

The Rubin Hancock site, located on an interfluve side slope immediately east of Walnut Creek, had sediments of greatly differing thicknesses occurring above gravels or calcareous bedrock (see Figure 3). Sixty-one of the $645 \times 5-\mathrm{ft}$ excavation units east of the E587+50 grid line had less than $0.5 \mathrm{ft}$ of sediments, with many encountering bedrock at the surface. Most of the historic artifacts and features came from this area. The soil was described as a dark brown sandy loam. Bedrock was not described, but photographs confirm that it was limestone, as would be expected for Austin Chalk. Elevations in this area range from 719 to $725 \mathrm{ft}$ above mean sea level. Thicker sediments and deeper excavations were located downslope west of the E587+50 grid line, as the interfluve slope flattened out toward Walnut Creek. Between elevations of 715 and $718 \mathrm{ft}$, gravels or bedrock were encountered at depths of more than $2 \mathrm{ft}$ and up to $6 \mathrm{ft}$. Closer to the creek, at elevations of 712 to $714 \mathrm{ft}$, gravels or bedrock were reached at shallower depths $(0.5-2.0 \mathrm{ft})$.

Deep sediments associated with the western part of 41TV875 were best represented in Units E586+95/N175 and E587+00/N175 and Trench 1. The two units were located at the north end of the excavation block associated with Trench 3 . These were the only two units excavated to bedrock within the block. Trench 1 was positioned $70 \mathrm{ft}$ south of the excavation block with an east-west orientation along the N80 grid line. Three other deep units-E587+45/N100, E587+25/N120, and E587+25/N130-were between the excavation block and Trench 1 , but descriptions of the sediments encountered within these units are minimal with only an indication that all ended in a zone of gravels.
Four stratigraphic zones were identified in Units E586+95/N175 and E587+00/N175 at the north end of the block (Figure 4). These were described as follows:

Zone 1, 0-12 inches, dark brown sandy loam with numerous roots;

Zone 2, 12-ca. 42 inches, light brown sandy loam with snail shells, small gravels, and caliche;

Zone 3, 42-54 inches, light brown sandy loam with gravels and caliche;

Zone 4, >54 inches, heavy gravels.

Zone 1 likely is a plow zone, as Rubin Hancock used the western part of the site as a garden area (see Blake and Myers 2000). Zone 4 also was described on the excavation record form for Unit E586+95/N175 as having a reddish sandy loam matrix. Excavations did not extend into Zone 4 . Thus, the maximum depth of these units was $4.5 \mathrm{ft}$.

Field notes show Trench 1 as $70 \mathrm{ft}$ long and $10 \mathrm{ft}$ deep. A north wall profile indicated that the trench exposed eight stratigraphic zones (Figure 5). These were described on the trench profile form as follows:

Zone 1, 0-17 inches, dark brown sandy loam;

Zone 2, 17-38 inches, medium brown sandy loam;

Zone 3, 38-60 inches, yellow brown sandy loam;

Zone 4, 60-74 inches, yellow brown sandy loam with small gravels;

Zone 5, 74-82 inches, red clay with gravels and cobbles;

Zone 6, 82-106 inches, medium brown sandy loam with small gravels;

Zone 7, 106-118 inches, yellow brown clay with few gravels;

Zone 8, limestone bedrock. 


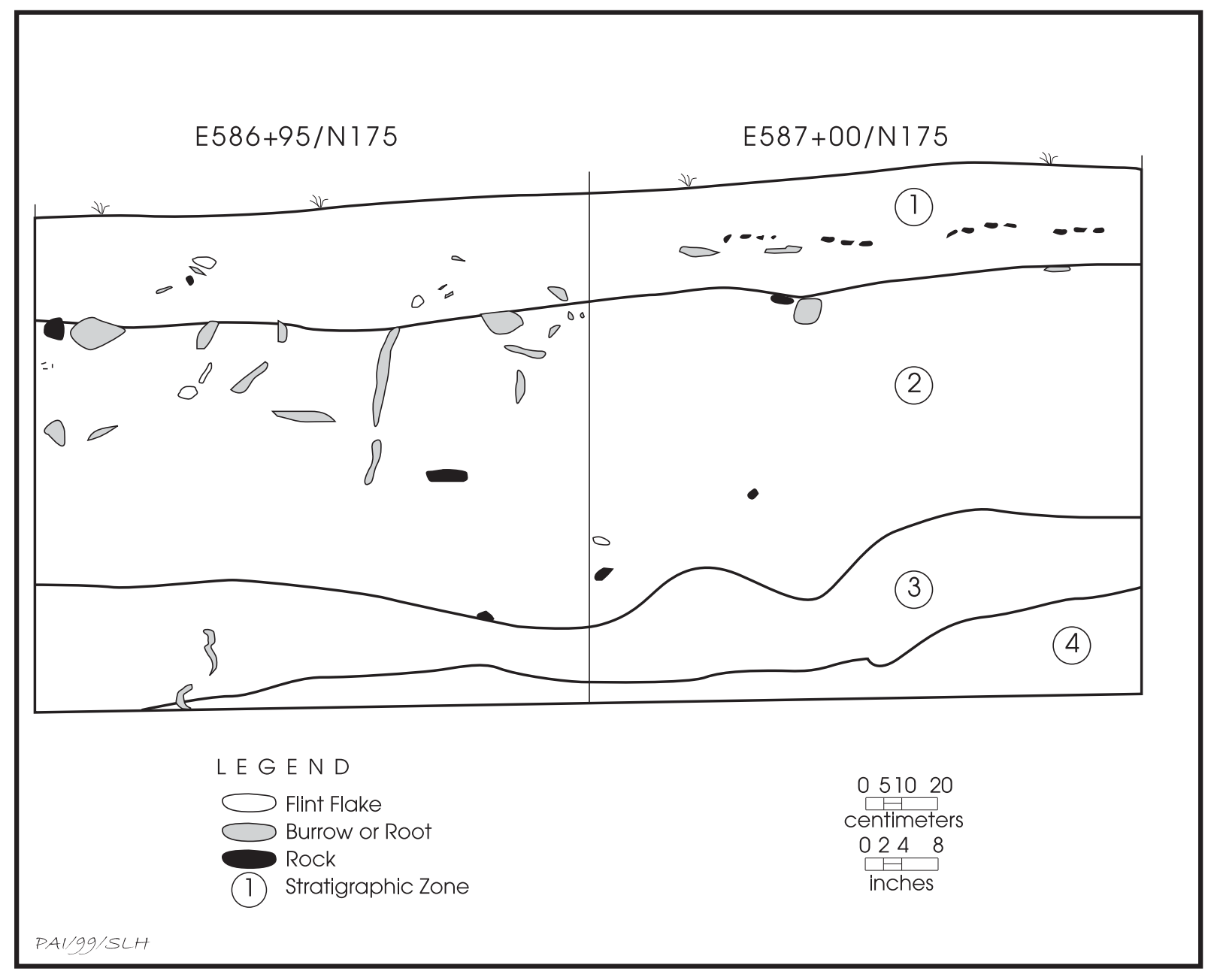

Figure 4. North profile of Units E586+95/N175 and E587+00/N175.

It appears that the first four zones correspond with the first three zones in the excavation units described above. While the excavation units stopped at a heavy gravel layer with a reddish matrix, the Gradall went through a similar layer (Zone 5) and exposed two additional sandy loam/clay zones with small or few gravels (Zones 6 and 7) before hitting bedrock. The lower zones, especially the contrasting layers of dense gravels and layers of small or few gravels, are suggestive of episodes of cutting and filling within a longabandoned channel of Walnut Creek. If the deep units and Trench 1 mark the course of this old channel, it would have followed the present orientation of Walnut Creek near the base of the interfluve slope. Such an old channel, acting as a natural sediment trap receiving alluvium from flood episodes as well as colluvium from the upper part of the interfluve, would explain why a pocket of deep soils remains in an area that otherwise has very shallow soils.

The different sizes of gravels within the fill zones exposed in Trench 1 suggest that depositional energies varied. For instance, the thick gravels of Zone 5 suggest a high-energy depositional environment, while the zones above and below Zone 5 suggest lower energy environments. After Zone 5 was deposited, filling of the old channel appears to have continued without additional major cutting episodes, suggesting that the stream had moved away from the old channel. The stability of the upper zones is emphasized by the presence of the burned rock concentration and debitage concentration in the excavation block (see 


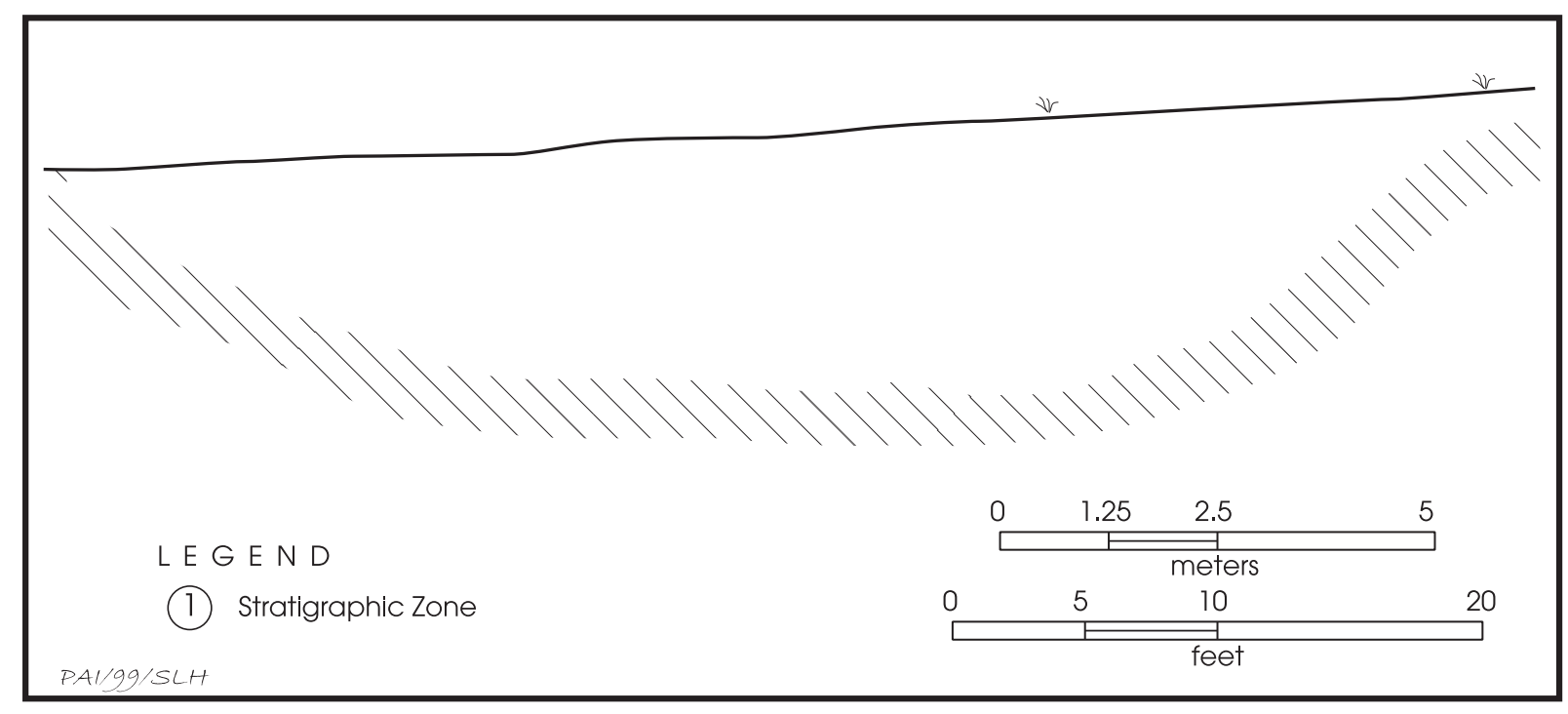

Figure 5. Profile of the north wall of Trench 1.

Features). The morphologies of these featuresespecially the tight configuration of the debitage concentration-indicate that the depositional environment was not energetic enough to disturb the feature constituents. The stability of the upper zones and the presence of features suggest that most of the cultural deposits in the western part of the site are the result of multiple superimposed living surfaces, rather than colluvial transport of artifacts from the higher eastern part of the site.

\section{Features}

Two features identified at 41TV875 were unquestionably related to the prehistoric components. These features consisted of a large burned rock concentration and a debitage concentration, both of which were in the excavation block west of Trench 3 . Several other small concentrations of burned and unburned rocks were identified in the thin deposits in the eastern half of the site. These small concentrations, consisting of fewer than 10 rocks were located in Units E588+15/N160, E588+35/ N140, and E588+45/N160. Since they more likely relate to the historic component, they are not discussed further here.

The extensive burned rock concentration was discovered in the wall of Trench 3 . At the request of the Texas Historical Commission, the concentration was investigated through the excavation of six units placed west of the trench (Figure 6). These units exposed part of the burned rock concentration and a debitage concentration that was labeled a cache. The entire debitage concentration was recovered by the excavation of an additional $2.5 \times 2.5$ - $\mathrm{ft}$ unit placed adjacent to Unit E586+95/N175. The burned rock and the debitage concentrations are described below.

\section{Burned Rock Concentration}

The rock concentration apparently was composed of both burned and unburned rocks, although counts for each cannot be reconstructed. Since Clark called the feature a hearth in his field notes and because the Texas Historical Commission asked that thermoluminesence samples be taken, it is assumed that most of the rocks were burned. The main cluster of rocks was exposed at approximately $1.0-2.0 \mathrm{ft}$ below the surface in Units E587+00/ N160 and E587+00/N165 (see Figure 6). A loose scatter extended out from those units to the north and south, with a deeper scatter of rocks to ca. $2.5 \mathrm{ft}$ at the north end of the block. The base of the feature likely was within the middle of Zone 2 as described above for E586+95/N175 and E587+00/N175, with the upper part of the zone forming the matrix around the rocks. 


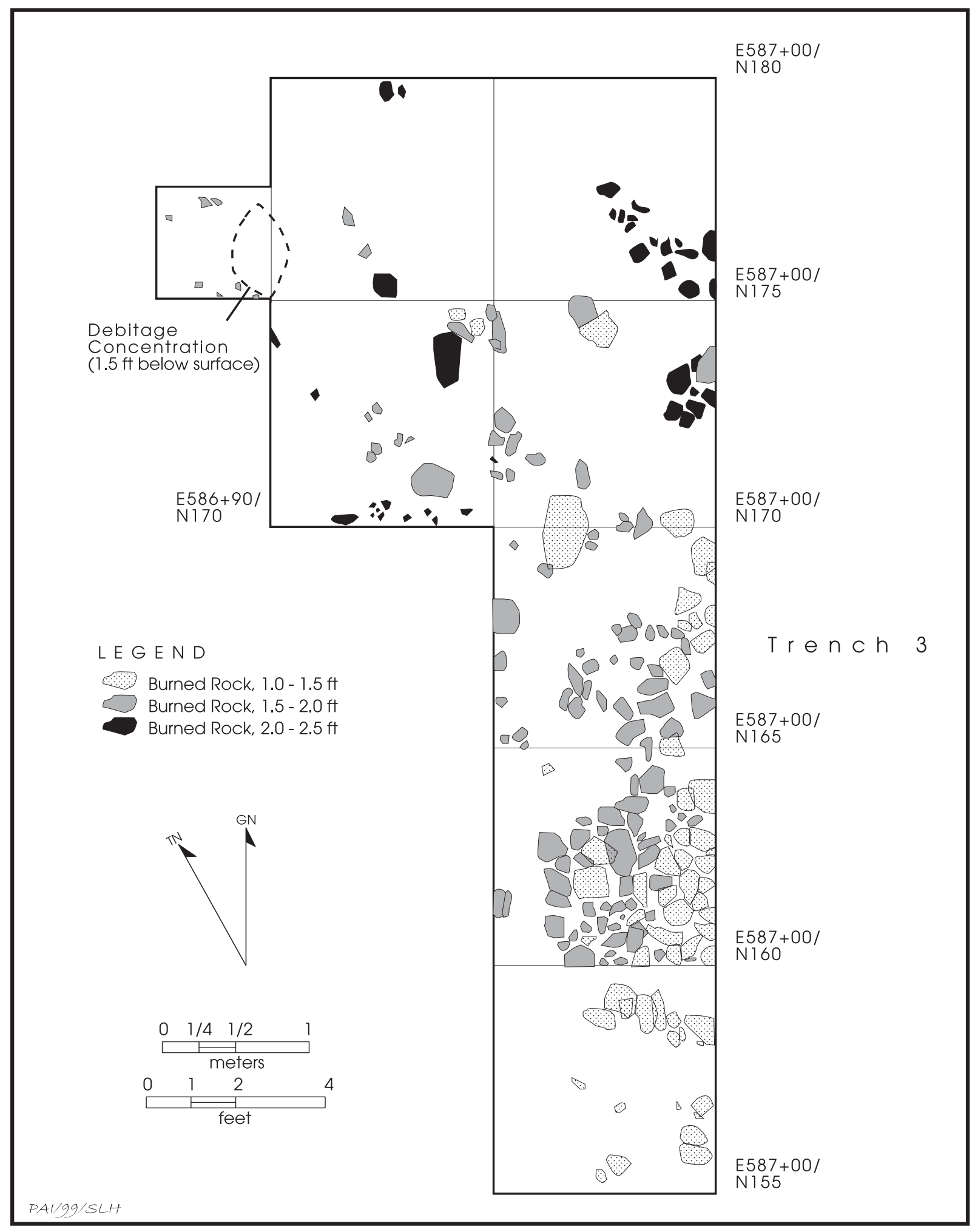

Figure 6. Plan of the burned rock concentration and debitage concentration in the excavation units adjacent to Trench 3. 
The plan view indicates that the feature was composed of 196 rocks within the six excavation units. No information exists on the number and configuration of the rocks originally identified in Trench 3. Though rock size was not measured in the field, the plan suggests that the rocks ranged from 2 to 20 inches in length. Larger rocks appear to have been relatively common at 1.0 to $1.5 \mathrm{ft}$, whereas smaller were more numerous at 1.5 to $2.0 \mathrm{ft}$ (Table 1). No information exists on the degree of burning associated with the various rock sizes. Also, there is no information as to whether the soil matrix showed evidence of burning or whether charcoal or artifacts were in direct association with the feature. At least 2,615 pieces of debitage, 49 lithic tools, and five core fragments were recovered from the same units and levels as the feature. Two of the tools are Paleoindian dart point fragments, while a third is a Middle Archaic point. A cross section of the main cluster of rocks within the feature along the N161 grid line suggests that the rocks were deposited on a relatively flat surface; only a hint of a shallow depression can be discerned (Figure 7). This cross section also shows that the rocks are piled 2 to 3 clasts deep with no discernible pattern.

Table 1. Vertical distribution of rocks in burned rock concentration

\begin{tabular}{rccc}
\hline Depth & $\begin{array}{c}\text { No. of Rocks } \\
<6 \text { inches }\end{array}$ & $\begin{array}{c}\text { No. of Rocks } \\
>6 \text { inches }\end{array}$ & Totals \\
\hline $1.0-1.5 \mathrm{ft}$ & $30(52 \%)$ & $28(48 \%)$ & 58 \\
$1.5-2.0 \mathrm{ft}$ & $72(73 \%)$ & $26(27 \%)$ & 98 \\
$2.0-2.5 \mathrm{ft}$ & $35(87 \%)$ & $5(13 \%)$ & 40 \\
Totals & $137(70 \%)$ & $59(30 \%)$ & 196 \\
\hline
\end{tabular}

Prehistoric burned rock features are common in central Texas, and their definition and function have been the focus of much recent reevaluation and research (e.g., Black et al. 1997; Kleinbach et al. 1995). Generally, accumulations of burned rocks are considered to be cooking/processing features such as kitchen middens or oven facilities. However, Black and Creel (1997:294) caution that there is too much variation in setting, form, and content to indicate that all such features represent a single function. Based on a synthesis of feature forms identified at Fort
Hood, the Rubin Hancock burned rock feature is most similar to "burned rock concentrations," as defined by Kleinbach et al. (1995:776). These features are described as shallow, amorphous, and generally one to two clasts thick with no internal structural components such as pits, ash stains, or rock pavements. Similarly, the Rubin Hancock feature's internal structure appears chaotic, the only discernible pattern being that there are more small rocks toward the base of the feature. The horizontal extent of burned rock concentrations can vary from 1 to $25 \mathrm{~m}$ (3.3$82.0 \mathrm{ft}$ ), while the thickness range is $0-40 \mathrm{~cm}$ $(0-1.3 \mathrm{ft})$. The part of the Rubin Hancock feature recorded on the plan view is $25 \mathrm{ft}$ across and less than $2 \mathrm{ft}$ thick. Most burned rock concentrations were found to have little other associated cultural materials. As noted above, the recovery of artifacts other than burned rocks near the 41TV875 feature was substantial. However, the questionable association between these materials and the feature makes comparisons with other burned rock concentrations problematic.

Some burned rock concentrations have been interpreted as probable dispersed hearths (Kleinbach et al. 1995:776). The 41TV875 feature may be interpreted in this fashion because of its lack of internal structure, charcoal, and in situ burned soils.

\section{Debitage Concentration}

A concentration of primarily large chert flakes, described as a "cache" during the 1987 excavations, was discovered at $1.5 \mathrm{ft}$ below the surface in the southwest corner of Unit E586+95/N175 and the eastern third of adjacent Unit E586+90/N175 (see Figure 6). There is no information on the configuration of the feature in Unit E586+95/N175, but the drawing and photograph of the feature in the unit to the west indicate that part of it consisted of a tight cluster of materials with a north-south length of 25 inches (Figure 8). The debitage within the feature appears to have been deposited on a flat surface; no associated pit feature was described by the excavators, nor does one appear in a closeup photograph of the western part of the feature. 


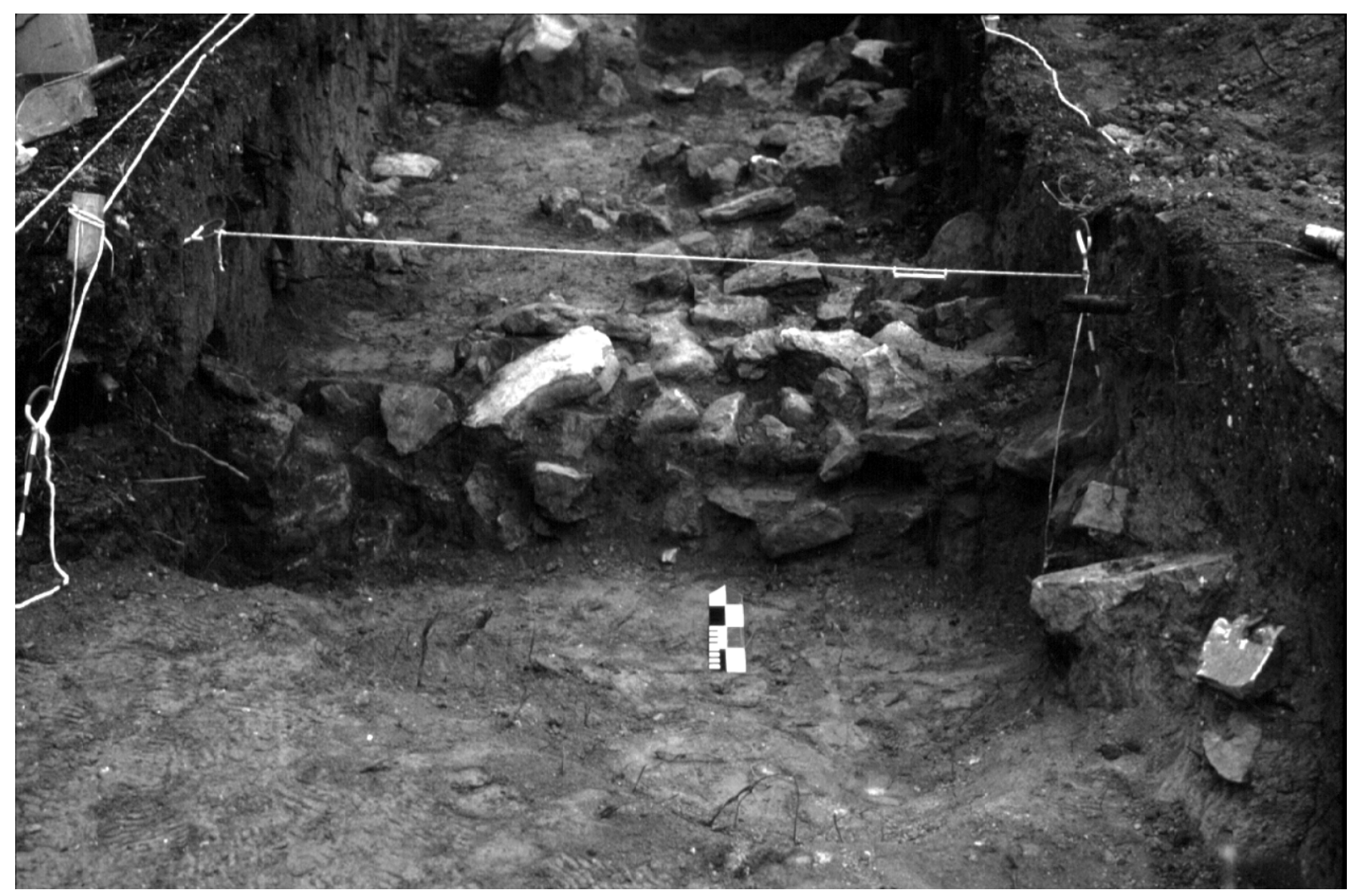

Figure 7. Cross section of burned rock concentration along the N161 grid line.

At $1.5 \mathrm{ft}$ below the surface, this debitage concentration appears to have been near the base of the main part of the burned rock concentration. The main concentration of burned rocks was ca. $10 \mathrm{ft}$ southeast of the debitage concentration. Like the burned rocks, the debitage concentration would have been within the upper part of Zone 2.

Materials recovered from the concentration consist of 217 pieces of debitage, 2 chunks of unaltered quartzite, 8 chunks of unaltered limestone, and 1 unidentifiable fossil fragment. The size range of the unaltered materials is 2 $10 \mathrm{~cm}$ in length. Of the total recovery, 158 items came from E586+90/N175 and 70 items were from E586+95N175. Thus, the part of the feature in E586+90/N175, as pictured in Figure 8, likely was twice the size of the part in E586+95/N175. All the debitage is a gray to blue-gray Edwards chert. This material would have been available locally due to the site's position near a fault line between the Austin Chalk and the chert-rich limestone of the Fredericksburg Group. Edwards chert would have occurred in bedrock outcrops and in secondary sources such as stream cobbles. Most of the chert artifacts in the concentration are either patinated or covered with a calcium carbonate rind; none of the materials exhibit evidence of heat treatment.

Over half the debitage consists of complete flakes ( $\mathrm{n}=122 ; 56$ percent), with chips making up the second largest group $(\mathrm{n}=62 ; 29$ percent $)$ followed by proximal flakes $(\mathrm{n}=24 ; 11$ percent) and chunks ( $\mathrm{n}=9 ; 4$ percent). The majority of the 208 complete flakes, chips, and proximal flakes ( $\mathrm{n}=149 ; 72$ percent) contain 25 percent or less dorsal cortex. Only 23 flakes (11 percent) have cortex on 25-75 percent of their dorsal surfaces, and just 14 (7 percent) have 75-100 percent dorsal cortex. Dorsal cortex percentage could not be determined on 22 specimens ( 11 percent), due to the presence of calcium carbonate. Generally, striking platforms on complete flakes and proximal fragments have single facets $(\mathrm{n}=101 ; 69$ percent). Multifaceted platforms occur on 35 flakes, 16 (11 percent) 


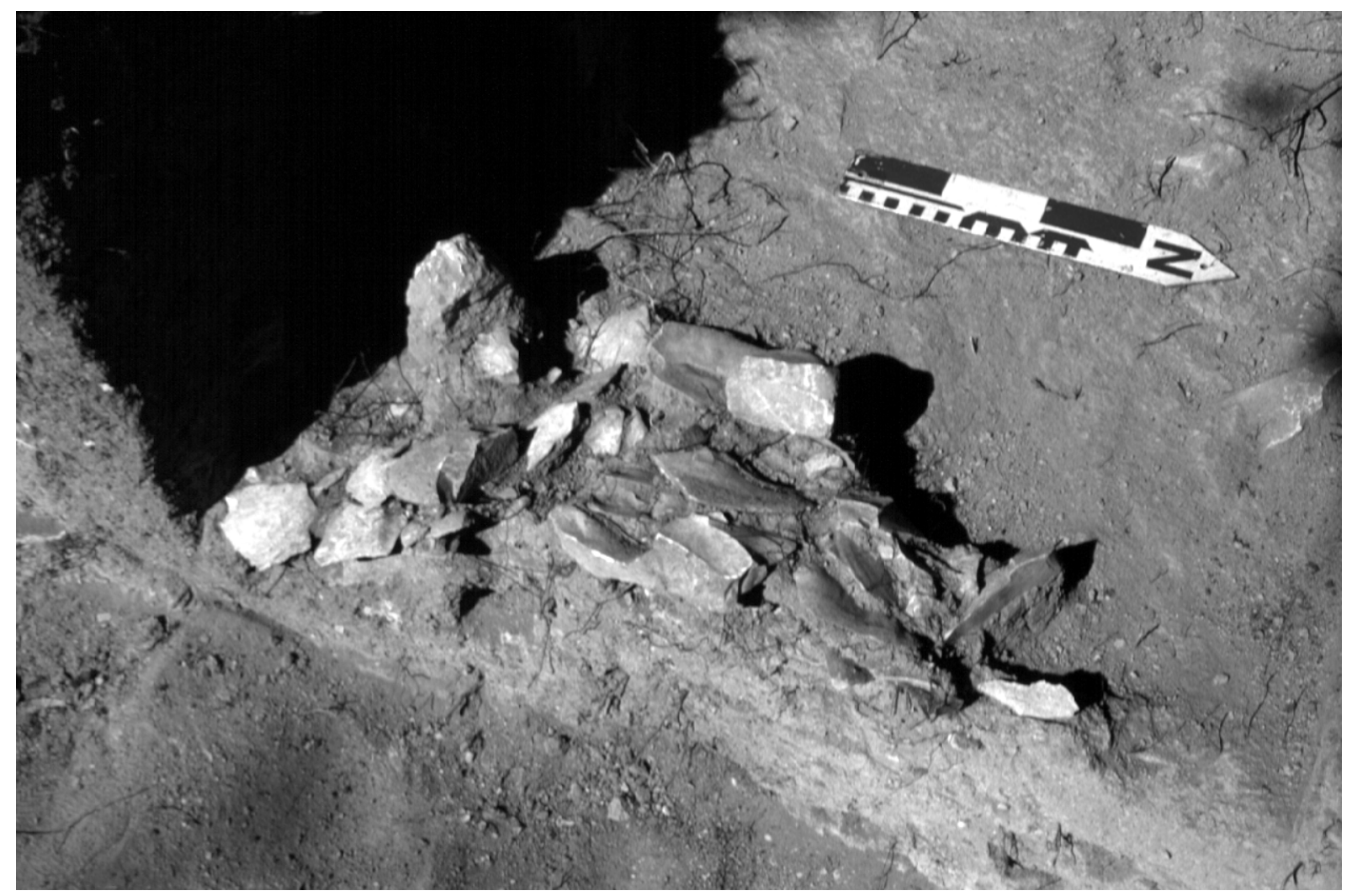

Figure 8. Debitage concentration exposed at ca.1.5 ft below the surface in E586+90/N175.

with two facets, 8 ( 5 percent) with three facets, and 11 (8 percent) with four or more facets. Platform faceting is indeterminate on 10 specimens (7 percent). Unground platforms ( $\mathrm{n}=50$; 34 percent) are more frequent than ground platforms ( $\mathrm{n}=29 ; 20$ percent), although determination of this attribute was hampered by calcium carbonate encrustations on almost half of the specimens ( $\mathrm{n}=67 ; 46$ percent).

The broken and complete flakes range in length between 1.0 and $17.0 \mathrm{~cm}$, with over half ( $\mathrm{n}=98 ; 47$ percent) being larger than $6.0 \mathrm{~cm}$ (Table 2). To determine whether chips and proximal fragments inflated the smaller size categories, thereby skewing the overall size distribution, the length of complete flakes alone was examined. This shows that the complete flakes tend to be larger, with 59 percent $(n=72)$ exceeding $6 \mathrm{~cm}$ (see Table 2 ).

Complete flakes, chips, and proximal fragments were further divided by flake type. As described above (see Analysis and Curation Methods), these types are general descriptors that incorporate flake shape with selected attributes. Type 1 flakes are considered to be core preparation flakes generated with the use of hard hammer reduction techniques (Figure 9). Type 2 flakes are considered secondary core reduction flakes (Figure 10a). Type 3 flakes are tertiary specimens considered late-stage core reduction flakes and/or bifacial thinning flakes (Figure 10b). Type 4, indeterminate flakes, do not fit any of the other types due to insufficient diagnostic traits.

Core preparation and initial reduction produced the largest number of flakes at 46 percent $(n=96)$, while secondary and late-stage reduction flakes make up 25 percent $(\mathrm{n}=51)$ and 10 percent $(n=21)$ of the sample, respectively. Forty specimens (19 percent) are classed as Type 4. A consideration of flake type by length indicates that core preparation flakes (Type 1) are the largest flakes; 63 percent $(\mathrm{n}=$ 60) are larger than $6.0 \mathrm{~cm}$ (Table 3). Type 2 specimens tend to be somewhat smaller, with 55 percent $(\mathrm{n}=28)$ larger than $6.0 \mathrm{~cm}$. More 
Table 2. Size breakdown for flakes in the debitage concentration

\begin{tabular}{c|cc|cc}
\hline \multirow{2}{*}{ Size $(\mathrm{cm})$} & \multicolumn{2}{|c|}{ All Flakes } & \multicolumn{2}{c}{ Complete Flakes } \\
\cline { 2 - 5 } & No. & $\%$ & No. & $\%$ \\
\hline $1.1-2.0$ & 17 & 8 & 5 & 4 \\
$2.1-3.0$ & 23 & 11 & 10 & 8 \\
$3.1-4.0$ & 29 & 14 & 12 & 10 \\
$4.1-5.0$ & 22 & 11 & 8 & 7 \\
$5.1-6.0$ & 19 & 9 & 15 & 12 \\
$6.1-7.0$ & 17 & 8 & 9 & 7 \\
$7.1-8.0$ & 18 & 9 & 10 & 8 \\
$8.1-9.0$ & 14 & 7 & 12 & 10 \\
$9.1-10.0$ & 22 & 11 & 16 & 13 \\
$10.1-11.0$ & 11 & 5 & 10 & 8 \\
$11.1-12.0$ & 10 & 5 & 10 & 8 \\
$12.1-13.0$ & 3 & 1 & 3 & 2 \\
$13.1-14.0$ & 1 & $<1$ & 1 & 1 \\
$14.1-15.0$ & 0 & 0 & 0 & 0 \\
$15.1-16.0$ & 0 & 0 & 0 & 0 \\
$16.1-17.0$ & 2 & 1 & 1 & 1 \\
Totals & 208 & ---- & 122 & ---- \\
\hline
\end{tabular}

than half of the Type 3 flakes ( $\mathrm{n}=12 ; 57$ percent) are $4.0 \mathrm{~cm}$ or less in size, and only 29 percent $(\mathrm{n}=$ 6 ) exceed $6.0 \mathrm{~cm}$. The large size of the core preparation and early reduction flakes suggests that the size of the cores was substantial. Larger flakes of all three types could have been shaped further as tools and/or preforms or used as expedient tools; however, little evidence for this occurs. Only four flakes show evidence of minimal unifacial modification. Three of these flakes are Type 1 and one is Type 2 . These four flakes range in length from 8 to $14 \mathrm{~cm}$.

Although originally identified as a cache, the characteristics of the debitage within the concentration suggest that it does not represent a true cache, which can be defined as an "accumulation of materials placed in storage or hiding for future recovery and utilization" (Miller 1993:1). The tight clustering of the mainly large flakes within at least part of the concentration likely was the basis for the original interpretation, and certainly many of the flakes are large enough to be reduced further or used expediently as tools. However, other flake characteristics-such as the large size range, nonuniform and often irregular shapes, and lack of evidence that they were intended for further reduction into tools-suggests that the feature may not have been a cache in the strict sense of the definition. Rather, the feature appears to represent a workshop area where core reduction took place with selected items removed for finishing elsewhere. A comparison of the debitage concentration from 41TV875 with examples of a flake cache and a lithic workshop site suggest that the flakes recovered from the concentration are more reminiscent of those recovered from a workshop.

Caches composed mainly of flakes and/or blades are moderately common in parts of Texas (Miller 1993:19-21). They often consist of whole flakes and/or blades (a blade may be defined as a flake that it is longer than it is wide), often along with a mixture of chips, tools, and/ or preforms. Most flake caches have been recovered from isolated contexts away from habitation sites, and sometimes are far from their original source.

In five west Texas caches reviewed by Tunnell (1978:40-46), two basic cache characteristics-uniform flake shape and occurrence away from habitation sites-are consistent. One flake cache that displayed these two basic characteristics is the Archaic period Gibson Cache recovered from a Cretaceous chert quarry site in Coke County, Texas (Tunnell 1978). This cache, consisting of 78 blades, was recovered from a small depression "no bigger than a hat" near the northern edge of the quarry site. Almost all specimens within the cache were complete, highly regular flakes with extensively trimmed edges. The length of the blades ranged from 5.5 to $11.8 \mathrm{~cm}$. No small flakes or chips were present, although they did litter the quarry site surrounding the cache. Cortex percentages were low due to extensive edge trimming, but only three specimens did not contain cortex. Platforms were single faceted and unprepared, although most were rectangular, thus indicating probable intentional placement of removal blows along an existing ridge-a technique suggesting systematic core reduction (Tunnell 1978:15-27). These characteristics indicate the intentional production of a homogeneous group of flakes/blades worked to a point where later they could be quickly finished into a specific kind of tool such as an end scraper (Tunnell 1978:51-54).

In contrast to the uniform flakes of a cache, such as the Gibson Cache, a workshop consists 


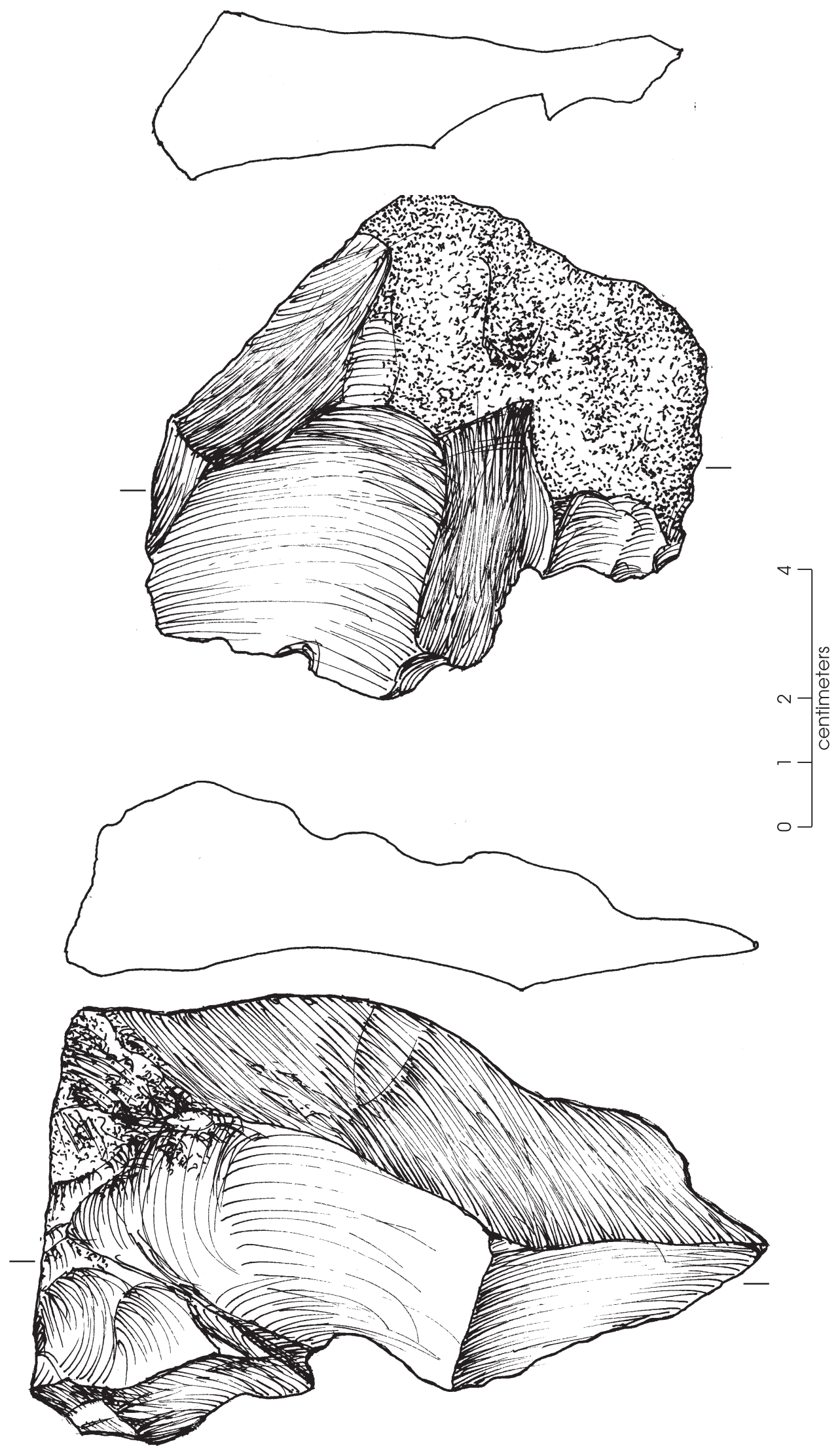

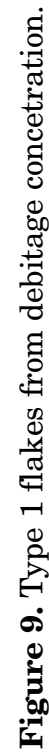




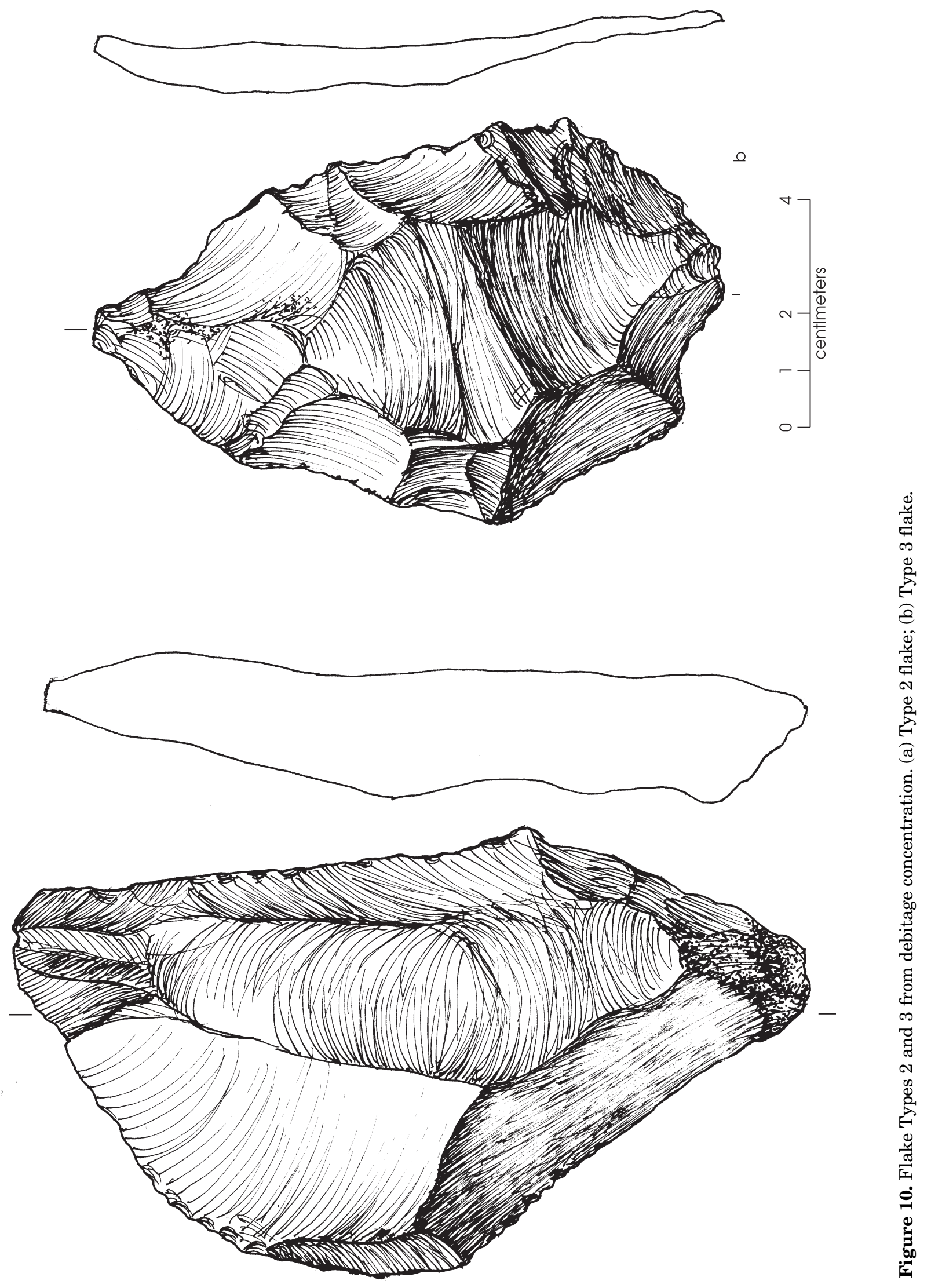


Table 3. Breakdown of debitage concentration by flake type

\begin{tabular}{|c|c|c|c|c|c|c|c|c|}
\hline \multirow{2}{*}{ Size $(\mathrm{cm})$} & \multicolumn{2}{|c|}{ Type 1} & \multicolumn{2}{|c|}{ Type 2} & \multicolumn{2}{|c|}{ Type 3} & \multicolumn{2}{|c|}{ Type 4} \\
\hline & No. & $\%$ & No. & $\%$ & No. & $\%$ & No. & $\%$ \\
\hline $1.1-2.0$ & 3 & 3 & 1 & 2 & 5 & 24 & 8 & 20 \\
\hline $2.1-3.0$ & 10 & 10 & 1 & 2 & 3 & 14 & 9 & 23 \\
\hline $3.1-4.0$ & 10 & 10 & 3 & 6 & 4 & 19 & 12 & 30 \\
\hline $4.1-5.0$ & 10 & 10 & 7 & 14 & 1 & 5 & 4 & 10 \\
\hline $5.1-6.0$ & 3 & 3 & 11 & 22 & 2 & 10 & 3 & 8 \\
\hline $6.1-7.0$ & 10 & 10 & 3 & 6 & 2 & 10 & 2 & 5 \\
\hline $7.1-8.0$ & 6 & 6 & 10 & 20 & 1 & 5 & 1 & 3 \\
\hline $8.1-9.0$ & 8 & 8 & 4 & 8 & 1 & 5 & 1 & 3 \\
\hline $9.1-10.0$ & 16 & 17 & 5 & 10 & 1 & 5 & 0 & 0 \\
\hline $10.1-11.0$ & 9 & 9 & 1 & 2 & 1 & 5 & 0 & 0 \\
\hline $11.1-12.0$ & 7 & 7 & 3 & 6 & 0 & 0 & 0 & 0 \\
\hline $12.1-13.0$ & 2 & 2 & 1 & 2 & 0 & 0 & 0 & 0 \\
\hline $13.1-14.0$ & 0 & 0 & 1 & 2 & 0 & 0 & 0 & 0 \\
\hline $14.1-15.0$ & 0 & 0 & 0 & 0 & 0 & 0 & 0 & 0 \\
\hline $15.1-16.0$ & 0 & 0 & 0 & 0 & 0 & 0 & 0 & 0 \\
\hline $16.1-17.0$ & 2 & 2 & 0 & 0 & 0 & 0 & 0 & 0 \\
\hline Totals & 96 & ---- & 51 & ---- & 21 & ---- & 40 & ---- \\
\hline
\end{tabular}

mainly of discarded materials or materials generated by tool, preform, and/or uniform flake manufacture. Feature 1 at the Yellow Hawk site, a probable Clovis-age workshop located in Taylor County, Texas, has been interpreted as one such material reduction area (Mallouf 1989:99). The feature measured $1.3 \mathrm{~m}$ in diameter and was reported to be roughly circular in shape. Forty-eight artifacts were recovered from the feature: 10 flakes, 10 chips, 7 blade-flakes, 6 blades, 2 bifaces, 12 cores, and 1 hammerstone. The 17 complete flakes, blades, and blade-flakes ranged from 2.0 to $12.9 \mathrm{~cm}$ in maximum length (Mallouf 1989:90). Thus, there were small flakes within the workshop sample that were missing from the Gibson Cache. The Yellow Hawk flakes varied in form and were suggested to be byproducts of core preparation. The bladeflakes were interpreted as resulting from unsystematic production, since their dorsal flake scars were multidirectional and thought to reflect only limited effort in the construction of ridges for later flake removal (Mallouf 1989:99). Flake and blade-flake bulbs of percussion and platforms were large and showed little preparation. Blades from the feature did not show significant edge trimming.
The characteristics of the flakes from the 41TV875 debitage concentration are similar to those of the Yellow Hawk lithic workshop. First, like the Yellow Hawk sample, flake length indicates a wide range of complete flake sizes and the presence of small flakes $(<3 \mathrm{~cm})$. In addition, proximal flakes, chips, and chunks make up nearly half the concentration. Flake shapes, cortex percentages, and degree of core preparation, as represented by the three flake types, suggest that material from the concentration is not particularly homogeneous but, rather, represents various stages of core reduction. The presence of some bifacial thinning flakes also suggests the application of different reduction techniques, adding to the lack of uniformity within the flake sample. Finally, the presence of some unaltered limestone and quartzite chunks suggests that this was not a carefully placed cache segregated from the surrounding occupational debris. All these factors suggest the debitage concentration was not a formal cache, but more likely was a work area from which local materials were added and subtracted. The fact that part of the feature consisted of a tight cluster of flakes may indicate that it was not significantly disturbed prior to or after burial. 


\section{Materials Recovered and Components Present}

Based on artifact counts in the original catalog, materials added to the catalog during this analysis, and minor reclassification of projectile points and bifaces during this analysis, 59,362 chipped stone artifacts were recovered from the Rubin Hancock site. These consist of 89 projectile points and point fragments, 629 bifaces, 5 unifaces, 89 other lithic tools, 85 cores, and 58,465 pieces of debitage. These materials are presented by provenience in the Appendix to this report. In a few instances, original chipped stone categories have been combined to streamline the inventory. Consequently, debitage counts include primary, secondary, and tertiary flakes, as well as counts for chunks, edge-modified flakes, bifacially modified flakes, and altered flakes, from the original catalog. It also should be noted that materials from the debitage concentration feature are included in the debitage category. Other lithic tools include scrapers, drills, gravers, and any other tool type not specifically categorized above. The accuracy of the identifications of items within each artifact category, other than projectile points, was not established during this study.

Other possible prehistoric materials recovered include 1,910 pieces of lithic materials cataloged as burned shatter, burned chert, and limestone chunks. Charcoal (92 fragments) and faunal materials (540 fragments) also were cataloged. The faunal materials include bones, shells, and teeth. No attempt was made to determine whether the charcoal or faunal materials were associated with the prehistoric or historic components, although it is likely that they are historic.

The projectile points were identified as to type by Elton R. Prewitt, using the criteria he established for his evaluation of the distributions of typed projectile points in Texas (Prewitt 1995:83-173). The points are listed in Table 4 . The majority of the types identified in the 41 TV875 catalog were not changed. However, a number of untypeable dart point fragments, including specimens relating to Early Archaic and Paleoindian occupations, were found in the biface categories. The identification of fragmentary early points was based on the presence of parallel flaking and basal/lateral grinding. In all, 58 points and point fragments were identifiable to type and/or time period. Examples of the more-complete specimens, grouped by time period, are illustrated in Figures 11 and 12.

These diagnostic points indicate the site was occupied from the latter part of the Paleoindian period (ca. 8000 B.c.), through the Late Archaic period (ca. A.D. 900). A single Scallorn arrow point fragment suggests that an ephemeral Late Prehistoric component also is present. Thirtyfour percent of the diagnostic points appear to be Paleoindian, thereby suggesting that this component is the most substantial (Table 5). The Middle and Late Archaic periods are almost equally represented with 22 and 28 percent of the points, respectively. The Early Archaic component appears to have been more limited, as it produced only 14 percent of the total diagnostic points.

\section{Distribution of Artifacts}

The 59,362 chipped stone items recovered from 41 TV875 came from all 87 excavation units opened at the site. The quantities of these materials recovered from each unit ranged from 14 to 4,990 items, with shallow units $(1 \mathrm{ft}$ or less deep) producing an average of 188 artifacts (standard deviation $=194$ ) and deep units (more than $1 \mathrm{ft}$ deep) producing an average of 1,931 artifacts (standard deviation $=1,476$ ). Consequently, most of the materials ( $\mathrm{n}=44,431 ; 75$ percent) came from the deep units located west of the E587+50 grid line (including Unit E587+85/N20). Six of the units west of the E587+50 grid line, with a maximum depth of 4.5 to $6.0 \mathrm{ft}$, produced 34 percent $(\mathrm{n}=20,234)$ of the collection. These six units were either excavated to bedrock or stopped at a zone of dense gravels apparently associated with an abandoned and filled channel of Walnut Creek.

Of the 58 temporally diagnostic projectile points, 38 are from units west of E587+50 (including Unit E587+85/N20) and 20 are from units to the east of this (see Table 5). Projectile points associated with the various time periods were found in both parts of the site (except for the single Scallorn arrow point). Paleoindian points are especially common in the western area, suggesting that the focus of this early component was in the downslope part of the site. The Archaic materials are more equally distributed, although 
Table 4. Provenience of projectile points

\begin{tabular}{|c|c|c|}
\hline $\begin{array}{l}\text { Horizontal } \\
\text { Provenience }\end{array}$ & Vertical Provenience* & Point Type \\
\hline $\mathrm{E} 586+50 / \mathrm{N} 160$ & Level 2 & Bulverde base \\
\hline $\mathrm{E} 586+50 / \mathrm{N} 160$ & Level 3 & Nolan-like base \\
\hline $\mathrm{E} 586+80 / \mathrm{N} 100$ & Level 1 & Pedernales base \\
\hline $\mathrm{E} 586+80 / \mathrm{N} 100$ & Level 1 & untyped dart stem \\
\hline E586+80/N100 & Level 1 & untyped dart distal fragment \\
\hline $\mathrm{E} 586+80 / \mathrm{N} 165$ & Level 6 & Angostura base \\
\hline $\mathrm{E} 586+80 / \mathrm{N} 165$ & Level 7 & untyped Late Paleoindian beveled blade \\
\hline E586+80/N165 & Level 7 & untyped rectangular-stem dart \\
\hline E586+80/N195 & Level $2(0-0.2 \mathrm{ft})$ & Bulverde \\
\hline E586+80/N195 & Level $3(0.2-0.5 \mathrm{ft})$ & untyped dart base \\
\hline E586+80/N195 & Level $3(0.2-0.5 \mathrm{ft})$ & untyped Late Paleoindian base \\
\hline E586+80/N195 & Level $4(0.5-1.0 \mathrm{ft})$ & untyped Late Paleoindian lanceolate \\
\hline E586+80/N195 & Level $4(0.5-1.0 \mathrm{ft})$ & untyped Late Paleoindian lanceolate \\
\hline $\mathrm{E} 586+95 / \mathrm{N} 170$ & Level 2 & untyped dart \\
\hline E586+95/N170 & Level 2 & untyped dart medial fragment \\
\hline E586+95/N170 & Level 4 & untyped Late Paleoindian medial fragment \\
\hline $\mathrm{E} 587+00 / \mathrm{N} 155$ & Level 3 & untyped Paleoindian medial fragment \\
\hline $\mathrm{E} 587+00 / \mathrm{N} 155$ & Level 3 & untyped dart \\
\hline $\mathrm{E} 587+00 / \mathrm{N} 160$ & Level $1(0-2.0 \mathrm{ft})$ & Scallorn \\
\hline $\mathrm{E} 587+00 / \mathrm{N} 160$ & Level $1(0-2.0 \mathrm{ft})$ & untyped Late Paleoindian distal fragment \\
\hline $\mathrm{E} 587+00 / \mathrm{N} 160$ & Level $1(0-2.0 \mathrm{ft})$ & untyped Late Paleoindian distal fragment \\
\hline $\mathrm{E} 587+00 / \mathrm{N} 165$ & Level $2(1.0-1.5 \mathrm{ft})$ & Travis \\
\hline $\mathrm{E} 587+00 / \mathrm{N} 170$ & Level $1(0-1.5 \mathrm{ft})$ & Plainview base \\
\hline $\mathrm{E} 587+00 / \mathrm{N} 170$ & Level $1(0-1.5 \mathrm{ft})$ & Pedernales base \\
\hline $\mathrm{E} 587+00 / \mathrm{N} 170$ & Level $1(0-1.5 \mathrm{ft})$ & Uvalde base \\
\hline $\mathrm{E} 587+00 / \mathrm{N} 170$ & Level $1(0-1.5 \mathrm{ft})$ & untyped dart medial fragment \\
\hline $\mathrm{E} 587+00 / \mathrm{N} 170$ & Level $1(0-1.5 \mathrm{ft})$ & untyped dart distal fragment \\
\hline $\mathrm{E} 587+00 / \mathrm{N} 170$ & Level $1(0-1.5 \mathrm{ft})$ & untyped dart distal fragment \\
\hline $\mathrm{E} 587+00 / \mathrm{N} 175$ & Level 1 & untyped dart \\
\hline $\mathrm{E} 587+00 / \mathrm{N} 175$ & Level 1 & Uvalde \\
\hline $\mathrm{E} 587+00 / \mathrm{N} 175$ & Level 1 & Bulverde-like base \\
\hline $\mathrm{E} 587+00 / \mathrm{N} 175$ & Level 1 & untyped dart distal fragment \\
\hline $\mathrm{E} 587+00 / \mathrm{N} 175$ & Level 1 & untyped dart distal fragment \\
\hline $\mathrm{E} 587+00 / \mathrm{N} 175$ & Level 2 & untyped dart distal fragment \\
\hline $\mathrm{E} 587+00 / \mathrm{N} 175$ & Level 3 & untyped dart distal fragment \\
\hline $\mathrm{E} 587+25 / \mathrm{N} 120$ & Level 7 & untyped Paleoindian medial fragment \\
\hline $\mathrm{E} 587+25 / \mathrm{N} 120$ & Level 7 & Taylor base \\
\hline $\mathrm{E} 587+25 / \mathrm{N} 130$ & Level 2 & Darl \\
\hline $\mathrm{E} 587+25 / \mathrm{N} 130$ & Level 2 & Angostura \\
\hline
\end{tabular}


Table 4, continued

\begin{tabular}{|c|c|c|}
\hline $\begin{array}{l}\text { Horizontal } \\
\text { Provenience }\end{array}$ & Vertical Provenience* & Point Type \\
\hline E587+25/N130 & Level 2 & Andice medial fragment \\
\hline $\mathrm{E} 587+25 / \mathrm{N} 130$ & Level 7 & Plainview base \\
\hline $\mathrm{E} 587+25 / \mathrm{N} 160$ & Level 1 & untyped dart medial fragment \\
\hline $\mathrm{E} 587+25 / \mathrm{N} 160$ & Level 1 & Darl \\
\hline $\mathrm{E} 587+25 / \mathrm{N} 160$ & Level 1 & Plainview base \\
\hline $\mathrm{E} 587+25 / \mathrm{N} 160$ & Level 1 & Bulverde \\
\hline $\mathrm{E} 587+25 / \mathrm{N} 160$ & Level 1 & untyped dart barb \\
\hline $\mathrm{E} 587+25 / \mathrm{N} 160$ & Level 5 & untyped dart distal fragment \\
\hline $\mathrm{E} 587+45 / \mathrm{N} 100$ & Level $1(0-5.0 \mathrm{ft})$ & Bulverde \\
\hline $\mathrm{E} 587+45 / \mathrm{N} 100$ & Level $1(0-5.0 \mathrm{ft})$ & untyped rectangular-stem dart \\
\hline $\mathrm{E} 587+45 / \mathrm{N} 100$ & Level $1(0-5.0 \mathrm{ft})$ & Bell barb \\
\hline $\mathrm{E} 587+45 / \mathrm{N} 100$ & Level $1(0-5.0 \mathrm{ft})$ & Taylor medial fragment \\
\hline E587+50/N55 & Level 1 & Plainview base \\
\hline $\mathrm{E} 587+55 / \mathrm{N} 155$ & Level 1 & Marshall base \\
\hline $\mathrm{E} 587+60 / \mathrm{N} 150$ & Level 1 & untyped dart medial fragment \\
\hline $\mathrm{E} 587+60 / \mathrm{N} 150$ & Level 1 & untyped dart medial fragment \\
\hline $\mathrm{E} 587+60 / \mathrm{N} 175$ & Level 1 & Gower \\
\hline E587+60/N175 & Level 1 & untyped Paleoindian base \\
\hline $\mathrm{E} 587+60 / \mathrm{N} 175$ & Level 1 & untyped Late Paleoindian base \\
\hline E587+60/N175 & Level 1 & untyped dart distal fragment \\
\hline $\mathrm{E} 587+60 / \mathrm{N} 180$ & Level 1 & Darl stem \\
\hline $\mathrm{E} 587+65 / \mathrm{N} 120$ & Level 1 & untyped dart proximal fragment \\
\hline $\mathrm{E} 587+65 / \mathrm{N} 175$ & Level $1(0-0.8 \mathrm{ft})$ & Marshall base \\
\hline E587+65/N175 & Level $1(0-0.8 \mathrm{ft})$ & untyped dart barb \\
\hline $\mathrm{E} 587+75 / \mathrm{N} 140$ & Level 1 & untyped dart distal fragment \\
\hline $\mathrm{E} 587+80 / \mathrm{N} 100$ & Level 1 & Ensor \\
\hline $\mathrm{E} 587+85 / \mathrm{N} 20$ & Level 2 & Bulverde \\
\hline $\mathrm{E} 587+85 / \mathrm{N} 20$ & Level 3 & Bell/Andice \\
\hline $\mathrm{E} 587+85 / \mathrm{N} 20$ & Level 3 & Nolan stem \\
\hline $\mathrm{E} 587+85 / \mathrm{N} 20$ & Level 5 (2.5-3.0 ft) & Martindale \\
\hline $\mathrm{E} 588+00 / \mathrm{N} 140$ & Level 1 & untyped dart barb \\
\hline $\mathrm{E} 588+00 / \mathrm{N} 140$ & Level 1 & untyped dart distal fragment \\
\hline E588+05/N130 & Level 1 & untyped Early Archaic/Late Paleoindian dart base \\
\hline E588+15/N155 & Level 1 & untyped dart distal fragment \\
\hline $\mathrm{E} 588+20 / \mathrm{N} 80$ & Level 1 & untyped Early-Middle Archaic dart base \\
\hline $\mathrm{E} 588+25 / \mathrm{N} 160$ & Level 1 & untyped Early Archaic rectangular-stem dart \\
\hline E588+30/N130 & Level 1 & untyped dart distal fragment \\
\hline $\mathrm{E} 588+40 / \mathrm{N} 60$ & Level 1 & untyped Early Archaic dart \\
\hline $\mathrm{E} 588+40 / \mathrm{N} 60$ & Level 1 & Bell/Andice \\
\hline
\end{tabular}


Table 4, continued

\begin{tabular}{lll}
\hline $\begin{array}{l}\text { Horizontal } \\
\text { Provenience }\end{array}$ & Vertical Provenience* & Point Type \\
\hline E588+40/N100 & Level 2 $(0.2 \mathrm{ft}-$ bedrock $)$ & untyped dart base \\
E588+40/N100 & Level 2 $(0.2 \mathrm{ft}$-bedrock $)$ & untyped Late Archaic dart \\
E588+40/N100 & Level 2 $(0.2 \mathrm{ft}-$ bedrock $)$ & Nolan \\
E588+40/N100 & Level $2(0.2 \mathrm{ft}-$ bedrock $)$ & untyped Early Archaic dart base \\
E588+40/N100 & Level 2 $(0.2 \mathrm{ft}-$ bedrock $)$ & Angostura proximal fragment \\
E588+45/N140 & Level 1 & untyped dart distal fragment \\
E588+45/N160 & Level 1 & Travis stem \\
E588+55/N50 & Level 1 & Baird medial fragment \\
E588+55/N55 & Level 1 & Darl base \\
E588+60/N50 & Level 1 & untyped Early Archaic lanceolate dart base \\
Trench 3 & ---- & untyped Late Paleoindian \\
\hline$*$ Unless noted otherwise, vertical provenience refers to 0.5-ft levels below ground surface, although many \\
units consisted only of Level 1, less than 0.5 ft thick. \\
\hline
\end{tabular}

Late and Middle Archaic points are substantially more common in the western area.

The diagnostic points from the eastern half of 41TV875 likely represent a series of occupations that occurred over a period of ca. 9,000 years. Given the long time span and the thinness of the sediments in this area, it is certain that the prehistoric materials are mixed. The eastern half of the site also was the area that contained the structures associated with the late-nineteenth- and early-twentiethcentury occupation. This historic occupation was another factor that likely compromised the integrity of the prehistoric deposits in this part of the site.

The deeper sediments in the western part of the site had a much better chance of containing intact and relatively unmixed prehistoric deposits. An assessment of whether such deposits were present can be made by looking at the distributions of the diagnostic projectile points and other artifacts. However, it should be noted that the quality of information concerning the vertical distribution of artifacts within the 24 western units varies. For instance, Unit E587+10/N165 was opened specifically to recover a historic dog burial, and, while artifacts were collected, the unit was excavated only to $0.5 \mathrm{ft}$ below the surface. Also, Unit E587+45/N100, which was $5 \mathrm{ft}$ deep, was excavated as a single level. In addition, levels were not maintained during the removal of sediments above the burned rock feature in Units E587+00/N160, E587+00/N165, and $\mathrm{E} 587+00 / \mathrm{N} 170$, nor is information available for artifact frequencies above the debitage concentration in the partial Unit E586+90/ N175. Although the data from these problematical units are presented in Table 6, they are not used in the analysis of the distribution of chipped stone materials.

Excavations in the western units were terminated for various reasons. Consequently, the units ranged in depth from 0.5 to $6.0 \mathrm{ft}$. Most units were excavated to at least $1.5 \mathrm{ft}$ whether or not bedrock or gravels were encountered $(\mathrm{n}=21)$. It was at 1.0 to $1.5 \mathrm{ft}$ that both features-the burned rock concentration and the debitage concentration-first appeared (see Table 6). Units E586+95/N175 and E587+00/N175 were taken below the features to $4.5 \mathrm{ft}$, at which point at least Unit E587+00/N175 reached dense gravels. In addition, five units reached gravels between 3.5 and $6.0 \mathrm{ft}$. These units were located northwest (Unit E586+80/N195) and southeast (Units E587+25/N120, E587+25/N130, $\mathrm{E} 587+45 / \mathrm{N} 100$, and $\mathrm{E} 587+50 / \mathrm{N} 55)$ of the feature area. The units within the feature area and the five deep units likely follow the course of the abandoned creek channel identified in Trench 1. Units to the east and west of these deep units are shallower and apparently define 


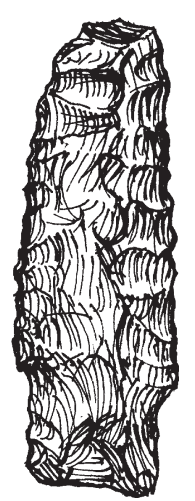

a

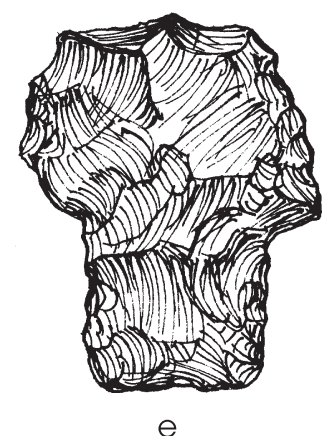

e
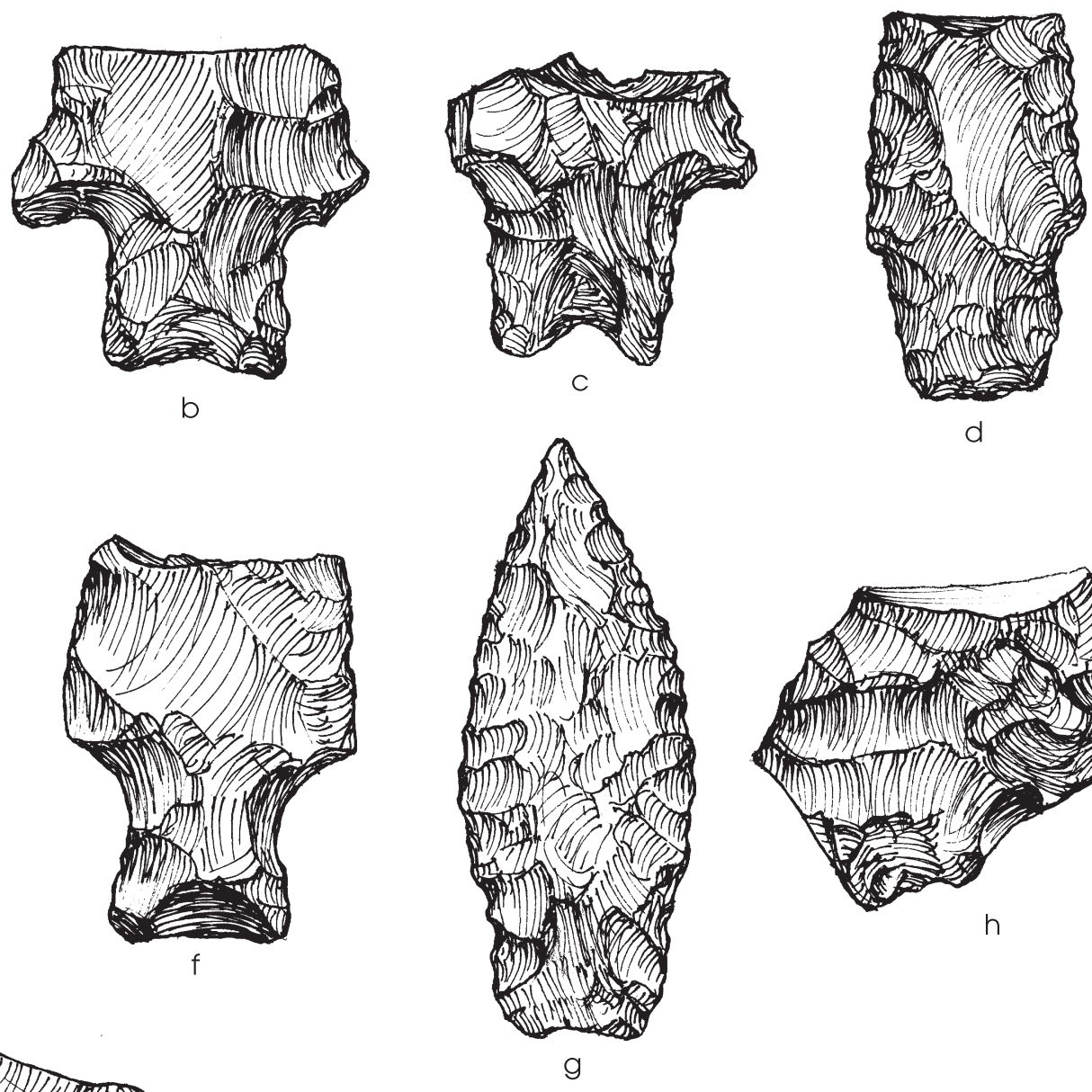

d
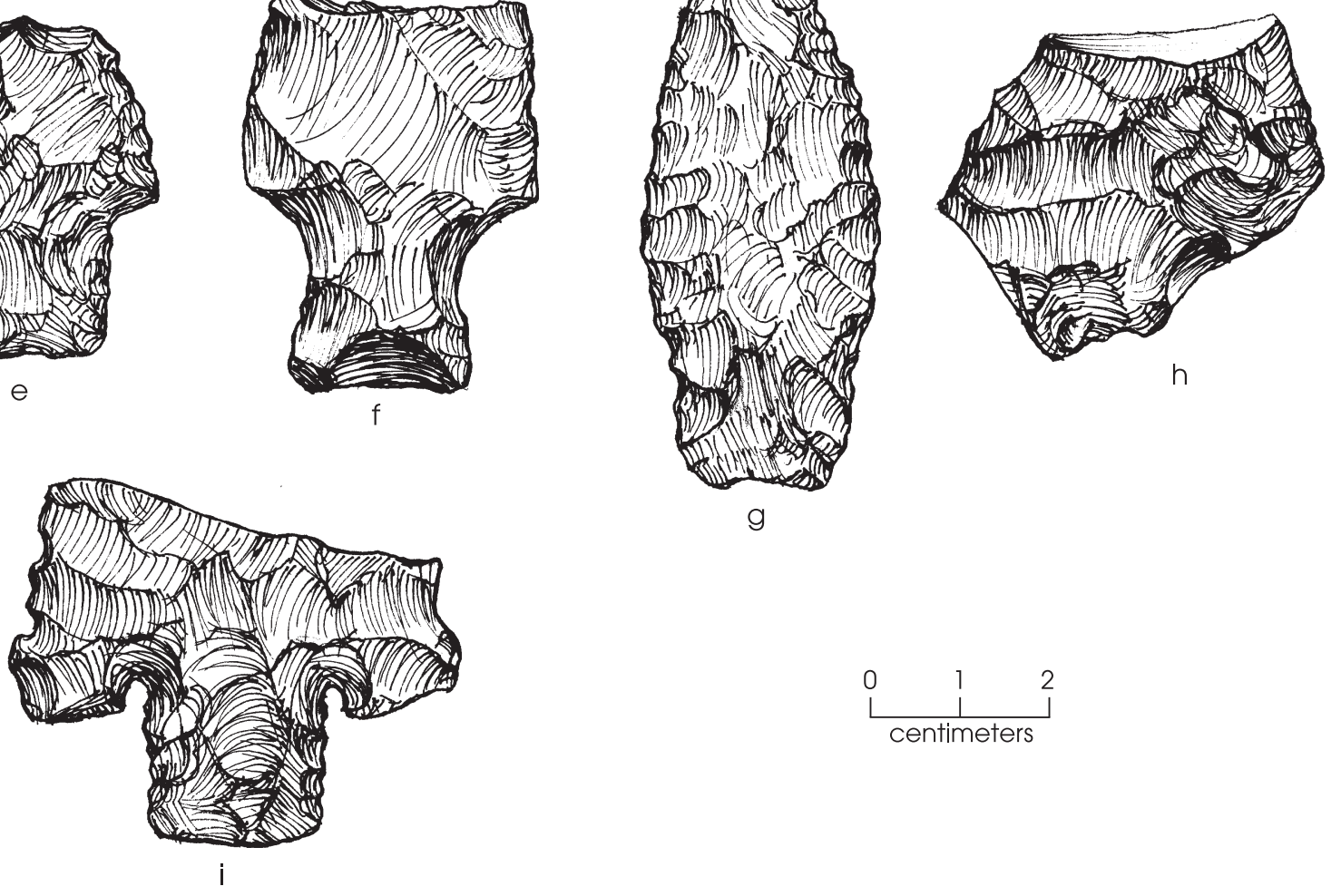

g

Figure 11. Late and Middle Archaic projectile points. (a) Darl; (b) Marshall; (c) Pedernales; (d-e) Bulverde; (f) Nolan; (g) Travis; (h) Taylor; (I) Bell/Andice.

the edges of the abandoned channel. Based on the placement of the features, it appears that the upper ca. $1.5 \mathrm{ft}$ of sediments is associated with Zone 1 and the upper part of Zone 2. Zone 1 , described as a dark brown sandy loam, may be a plow zone. Plowing would have been a major disturbance to the upper artifact deposits.

Diagnostic artifacts recovered from the upper $1.5 \mathrm{ft}$ consist of the following: nine Late Archaic points (five Bulverde, two Darl, and two Pedernales); five Middle Archaic points (two Bell/Andice, two Nolan, and one Travis); two Early Archaic Uvalde points; and eight Paleoindian points (one Angostura, three Plainview, two untyped lanceolate points, one untyped base fragment, and one untyped medial 

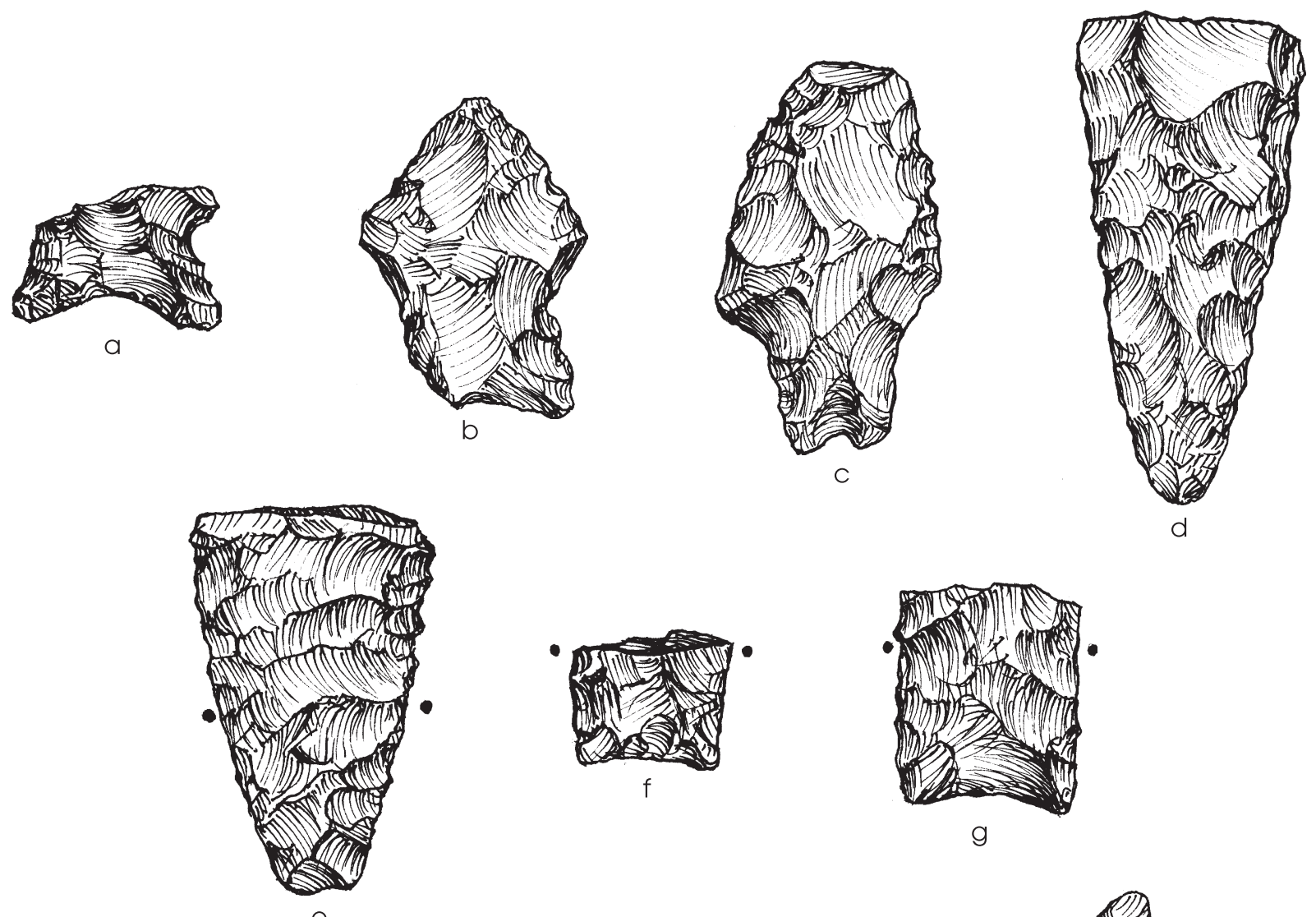

g

e

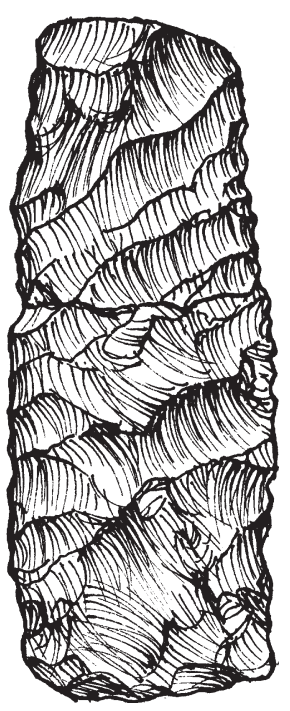

$\mathrm{h}$
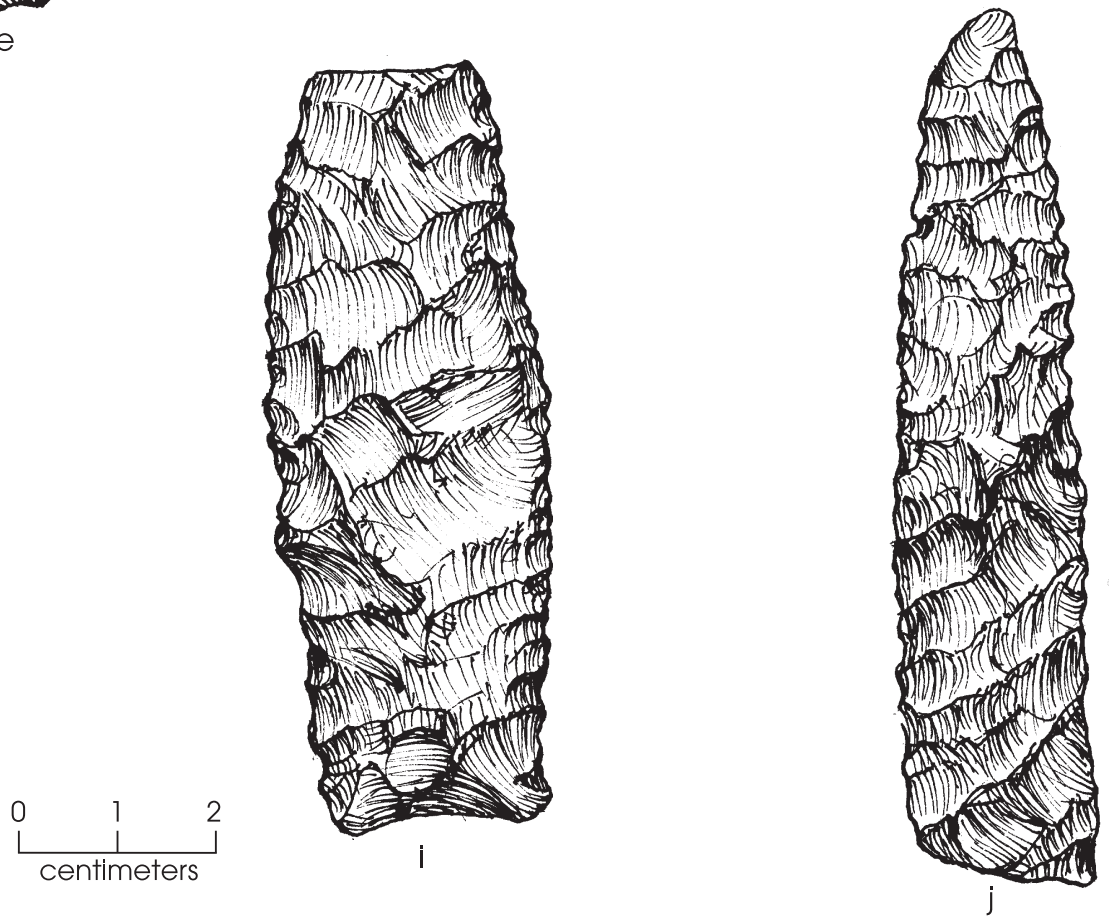

Figure 12. Early Archaic and Paleoindian projectile points. (a) Martindale; (b) Uvalde; (c) Gower; (d-e) Angostura; (f-g) Plainview; (h-j) untyped Late Paleoindian lanceolate. (Note: Extent of edge grinding indicated by dots). 
Table 5. Distribution of diagnostic points by time period and site area

\begin{tabular}{|c|c|c|c|c|}
\hline \multirow{2}{*}{ Type } & \multirow{2}{*}{ Eastern Area } & \multirow{2}{*}{ Western Area } & \multicolumn{2}{|c|}{ Totals } \\
\hline & & & No. & $\%$ \\
\hline \multicolumn{5}{|l|}{ Late Prehistoric: } \\
\hline Scallorn & 0 & 1 & 1 & 2 \\
\hline Subtotals & 0 & 1 & 1 & 2 \\
\hline \multicolumn{5}{|l|}{ Late Archaic: } \\
\hline Darl & 2 & 2 & 4 & 7 \\
\hline Ensor & 1 & 0 & 1 & 2 \\
\hline Marshall & 2 & 0 & 2 & 3 \\
\hline Pedernales & 0 & 2 & 2 & 3 \\
\hline Bulverde & 0 & 6 & 6 & 10 \\
\hline Untyped Late Archaic & 1 & 0 & 1 & 2 \\
\hline Subtotals & 6 & 10 & 16 & 28 \\
\hline \multicolumn{5}{|l|}{ Middle Archaic: } \\
\hline Nolan & 1 & 2 & 3 & 5 \\
\hline Travis & 1 & 1 & 2 & 3 \\
\hline Baird & 1 & 0 & 1 & 2 \\
\hline Taylor & 0 & 2 & 2 & 3 \\
\hline Bell/Andice & 1 & 3 & 4 & 7 \\
\hline Untyped Early-Middle Archaic & 1 & 0 & 1 & 2 \\
\hline Subtotals & 5 & 8 & 13 & 22 \\
\hline \multicolumn{5}{|l|}{ Early Archaic: } \\
\hline Martindale & 0 & 1 & 1 & 2 \\
\hline Uvalde & 0 & 2 & 2 & 3 \\
\hline Gower & 1 & 0 & 1 & 2 \\
\hline Untyped Early Archaic & 4 & 0 & 4 & 7 \\
\hline Subtotals & 5 & 3 & 8 & 14 \\
\hline \multicolumn{5}{|l|}{ Paleoindian: } \\
\hline Angostura & 1 & 2 & 3 & 5 \\
\hline Plainview & 0 & 4 & 4 & 7 \\
\hline Untyped Early Archaic/Late Paleoindian & 1 & 0 & 1 & 2 \\
\hline Untyped Late Paleoindian & 1 & 8 & 9 & 16 \\
\hline Untyped Paleoindian & 1 & 2 & 3 & 5 \\
\hline Subtotals & 4 & 16 & 20 & 34 \\
\hline Totals & 20 & 38 & 58 & 100 \\
\hline
\end{tabular}

fragment) (see Tables 5 and 6). Thus, Early, Middle, and Late Archaic and Paleoindian materials are well represented in the upper deposits without any clear separation. In addition, a Late Prehistoric component is represented by the one Scallorn point fragment recovered from the upper $2 \mathrm{ft}$ in Unit E587+00/ N160. The context of the materials within these upper levels also is made questionable by the presence of historic artifacts. In units where level information is consistent, historic artifacts were recovered consistently from the upper foot of deposits, with only an occasional isolated item found deeper (see Appendix). The distributional information indicates that the upper deposits in the western part of the site are mixed and disturbed, probably as a result of historic plowing, bioturbation, and slow sediment deposition. 


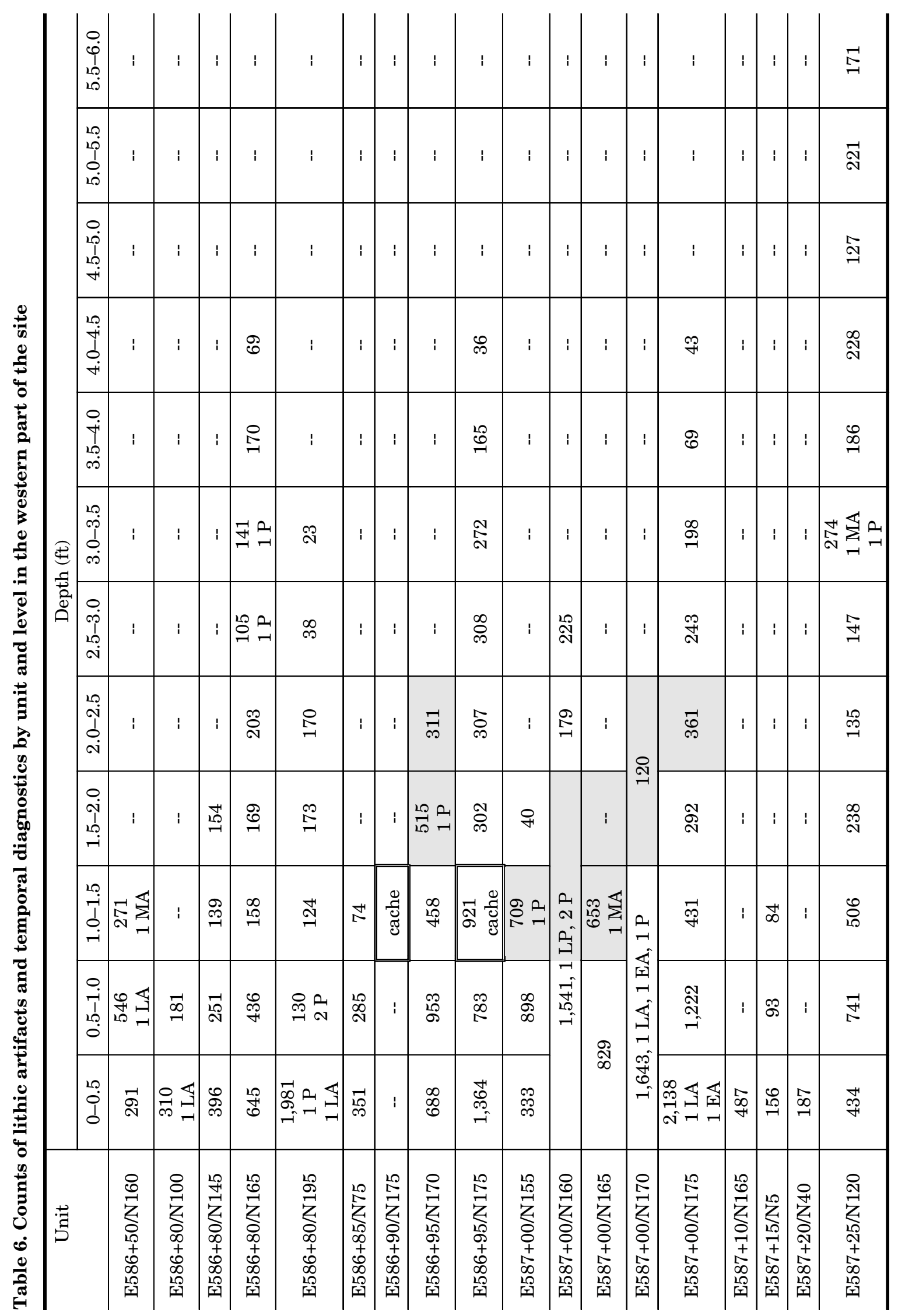



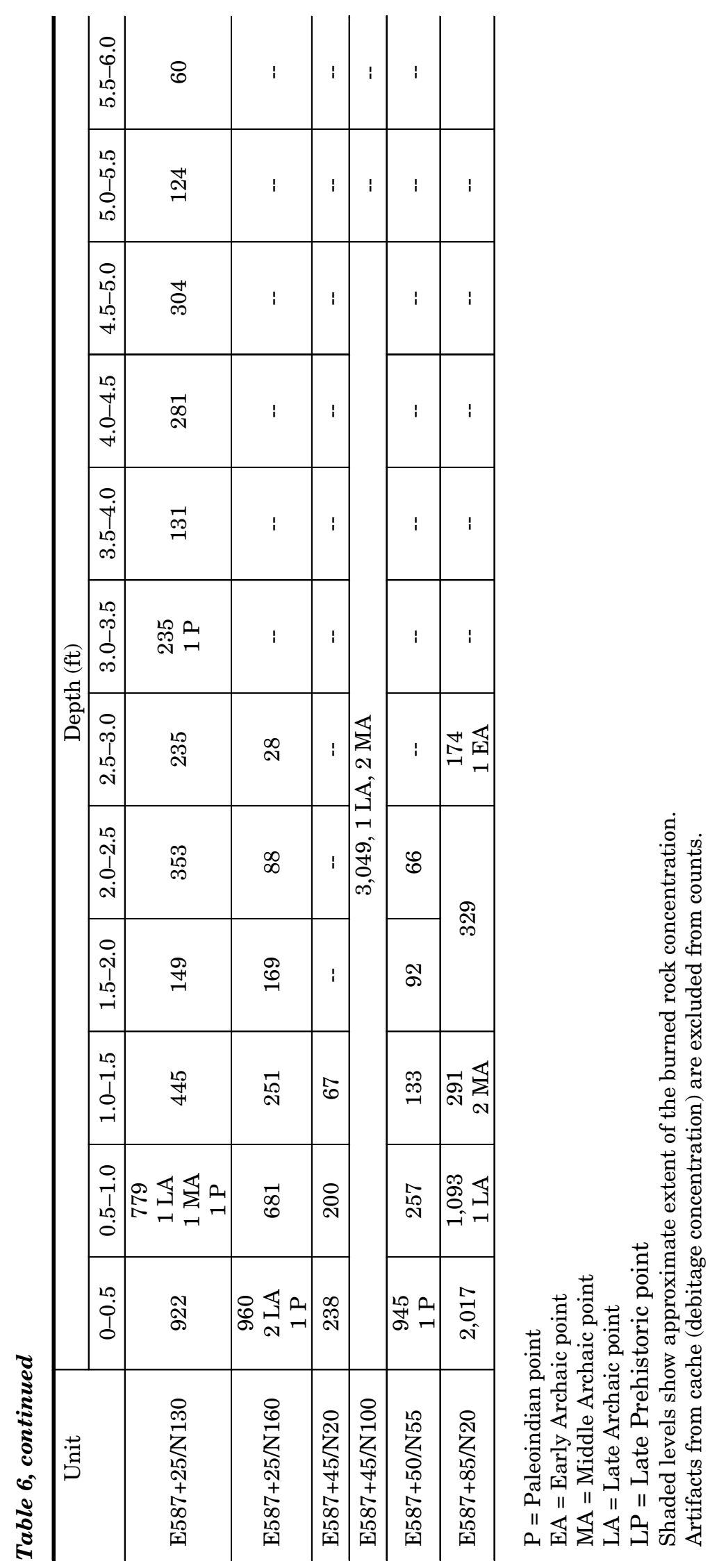
Within the deep units in and below the level of the features (i.e., below $1.5 \mathrm{ft}$ ) the diagnostic points are associated mainly with the Paleoindian/Late Paleoindian period: one Angostura, one Plainview, one untyped beveled blade, and two untyped medial fragments (see Tables 5 and 6). Earlier points from these deep levels consist only of one Early Archaic Martindale fragment and one Middle Archaic Taylor fragment. The presence of these points suggests that some mixing of the lower levels has occurred, although appreciably less than indicated in the upper levels.

Artifact frequencies plotted by depth support the conclusion that the cultural remains in the upper deposits are compressed (Table 7). Artifact densities are highest in the uppermost level and decrease consistently with depth, except for small increases at 2.0 to $2.5 \mathrm{ft}$ and 3.0 to $3.5 \mathrm{ft}$. A more substantial peak occurs at 4.5 to $5.5 \mathrm{ft}$ in the deepest units (E587+25/N130 and E587+25/N120). Coupled with the distributions of the diagnostic points, these artifact densities suggest occupations of moderate intensity during the Late Paleoindian period and possibly the Early Archaic period, as ca. $4 \mathrm{ft}$ of sediment was rapidly deposited within the abandoned channel of Walnut Creek. Deposition then appears to have slowed, allowing large quantities of debris relating to Paleoindian, Archaic, and Late Prehistoric occupations to accumulate in the upper 1.5-2.0 ft of sediment.

\section{SUMMARY AND RECOMMENDATIONS}

The Rubin Hancock site (41TV875) was occupied repeatedly by hunter-gatherers over a long span of prehistory. Based on diagnostic projectile points, these occupations began at the late end of the Paleoindian period, ca. 8000 B.C., and continued into the early part of the Late Prehistoric period, after ca. A.D. 900. The frequencies of the points indicate that the most intensive occupations occurred during the Late Archaic and Paleoindian periods, followed by the Middle and Early Archaic periods. An ephemeral Late Prehistoric component is represented by a single arrow point. Diagnostic artifacts associated with the Paleoindian and Archaic periods were recovered from across the site. However, the high percentage of Paleoindian points from the western half of the site suggests that the earliest occupations were concentrated in this area. Paleoindian point fragments were recovered from several deep units in the western half of the site, and it appears that a reasonably discrete early component may have been present in the lower levels of the deeper units. The upper deposits in the western area and the thin deposits in the eastern part of the site contained diagnostics from all time periods, indicating a mixing of components. The two prehistoric features identified-a burned rock feature and a debitage concentration-were in the area of thick sediments. Based on depth, both could be associated with early occupations, particularly

Table 7. Average artifact frequencies by level in the western part of the site

\begin{tabular}{cccc}
\hline Depth $(\mathrm{ft})$ & Total Artifacts & No. of Units & Average Artifact Frequency \\
\hline $0-0.5$ & 14,829 & 19 & 781 \\
$0.5-1.0$ & 9,617 & 17 & 561 \\
$1.0-1.5$ & 5,716 & 17 & 336 \\
$1.5-2.0$ & 2,418 & 12 & 208 \\
$2.0-2.5$ & 2,175 & 10 & 217 \\
$2.5-3.0$ & 1,468 & 9 & 167 \\
$3.0-3.5$ & 1,013 & 6 & 191 \\
$3.5-4.0$ & 592 & 5 & 144 \\
$4.0-4.5$ & 621 & 4 & 131 \\
$4.5-5.0$ & 431 & 2 & 216 \\
$5.0-5.5$ & 345 & 2 & 173 \\
$5.5-6.0$ & 231 & 2 & 116 \\
\hline
\end{tabular}


the deeper parts of the burned rock concentration. Later materials were found in moderate numbers at the same depth as the debitage concentration and the upper part of the burned rock concentration, however, and it is possible that the burned rock concentration was reused during multiple occupations. The debitage concentration is more likely to represent a single depositional episode. Given the lack of radiocarbon dates, it never will be possible to determine component associations with certainty.

Originally, the lithic debitage concentration was considered to be a cache. However, analysis of the materials contained within the concentration indicates that they are not particularly homogeneous, as would be expected from a formal cache. Instead, they consist of a wide range of flake types and sizes representing various reduction strategies and stages. In addition, there is little evidence that the materials were being prepared for further tool manufacture, and the presence of some unaltered limestone and quartzite chunks suggests that little attention was given to removing the feature materials from the surrounding milieu of the site. All these characteristics set this feature apart from most known flake caches, which tend to have more uniformity of the cached materials and tend to be located away from habitation sites. This debitage concentration can better be interpreted as a discard pile.

Based on extensive research of burned rock features in central Texas, the burned rock feature at 41 TV875 can be interpreted as the remains of some type of processing area. Its apparent lack of internal structure, charcoal, and in situ burning suggests that it is somewhat dispersed. Similar features have been identified in the Fort Hood area of central Texas (and elsewhere) and classified as simple burned rock concentrations.

Curation of the materials recovered was given careful consideration during this analysis because, although prehistoric artifacts were recovered from across the site, the quality of the contexts of those materials varies significantly. Extremely thin parts of the site, less than $0.5 \mathrm{ft}$ in depth and generally east of the E587+50 grid line, produced multi-component prehistoric materials mixed with historic artifacts. Similarly mixed are the upper deposits in the excavation units within the deeper deposits west of the E587+50 grid line (including Unit E587+85/N20). Most of the artifacts from these mixed contexts have a limited potential to contribute useful information, and it is recommended that they do not warrant curation. The only class of artifacts from these proveniences that should be retained is the projectile points. In contrast, the lower deposits in the deeper part of the site contain an early component that appears to have the potential to provide useful information for comparative studies with other early sites in central Texas. It is recommended that all artifacts from these deeper deposits-defined generously as everything below $1.0 \mathrm{ft}$ in the western part of the site-be retained for curation. In a few instances, entire deep units or parts of deep units were excavated as a single level. Materials from these units or parts of units should not be retained (except for projectile points) as they have become mixed through excavation techniques. In total, it is believed that 24 percent of the prehistoric materials from the Rubin Hancock site ( $\mathrm{n}=$ $14,926)$ have sufficient interpretive value to warrant curation.

Given the lack of associated materials such as faunal and macrobotanical remains, as well as the lack of radiocarbon dates and numerous features, the primary interpretive value of the early-component artifacts from 41TV875 lies in comparisons between this site and others with early components in terms of lithic assemblages. Such comparisons could focus on several lines of inquiry relating to the ranges of activities performed and group mobility, including investigation of tool kit content, assemblage organization, and lithic raw material procurement and lithic reduction strategies. 

GLOSSARY OF TECHNICAL TERMS 
A horizon: Mineral soil horizon at the surface (or below an O horizon) with little or no original rock/sediment structure and marked by accumulation of organic matter mixed with mineral fraction.

Alluvium: Deposits made by streams on river beds, floodplains, and alluvial fans.

B horizon: Mineral soil horizon (usually beneath an $\mathrm{O}, \mathrm{A}$, or $\mathrm{E}$ horizon) with little or no original rock/sediment structure, usually redder than horizons above and below, and marked by the following: alluvial concentration of clay, iron, aluminum, humus, carbonates, gypsum, and/or silica; leaching of carbonates; and/or blocky or prismatic structure.

Bulb of percussion: Bulbar area on the ventral flake surface just below the striking platform.

C horizon: Mineral soil horizon (other than $\mathrm{R}$ horizon) that lacks characteristics of $\mathrm{O}, \mathrm{A}, \mathrm{E}$, or B horizon, representing unaltered or slightly altered parent material.

Cache: Collection of items stored for future use.

Calcareous: Containing calcium carbonate.

Caliche: Sediment cemented by calcium carbonate.

Colluvium: Deposits made primarily by gravity at the base of a slope.

Core: Block of raw lithic material from which flakes were removed to make tools.

Cortex: Crust on the outer part of a piece of raw lithic material before flakes are removed.

Curation: Care and preservation of artifacts, records, and photographs generated by an archeological project.

Debitage: Lithic debris generated by the removal of flakes to make tools.

Evapotranspiration: Precipitation returned to the air by evaporation and transpiration.

Horticulture: Cultivation of a garden to produce food.

Interfluve: Uplands between generally parallel streams.

Lanceolate: Projectile point that lacks shoulders and tapers at both ends.

Megafauna: Very large animals.

Mesic: Relating to moderate climatic conditions.

Mesothermal: Climate characterized by moderate temperature.

Microfauna: Very small animals.

Mitigative excavations: Excavations to recover enough information from an archeological site to allow it to be interpreted before it is destroyed/damaged.

Patinated: Discoloration or thin layer on the surface of a rock created by weathering.

Platform: The part of the flake struck while removing it from the core or parent piece.

Privy: Latrine or outhouse.

Standard deviation: Statistic used to indicate dispersion in a distribution.

Stratigraphy: Study of the distribution, geometry, and age of rock/sediment strata.

Thermoluminescence: Property of emitting light when heated; in some instances, allows minerals to be dated.

Xeric: Relating to extremely dry climatic conditions. 


\section{REFERENCES CITED}

Black, Stephen L.

1989 Central Texas Plateau Prairie. In From the Gulf to the Rio Grande: Human Adaptation in Central, South, and Lower Pecos Texas, by Thomas R. Hester, Stephen L. Black, D. Gentry Steele, Ben W. Olive, Anne A. Fox, Karl J. Reinhard, and Leland C. Bement, pp. 17-38. Research Series No. 33 Arkansas Archeological Survey, Fayetteville.

Black, Stephen L., and Darrell G. Creel

1997 The Central Texas Burned Rock Midden Reconsidered. In Hot Rock Cooking on the Greater Edwards Plateau: Four Burned Rock Midden Sites in West Central Texas, vol. 1, by Stephen L. Black, Linda W. Ellis, Darrell G. Creel, and Glenn T. Goode, pp. 269-305. Studies in Archeology 22. Texas Archeological Research Laboratory, The University of Texas at Austin.

Black, Stephen L., Linda W. Ellis, Darrell G. Creel, and Glenn T. Goode

1997 Hot Rock Cooking on the Greater Edwards Plateau: Four Burned Rock Midden Sites in West Central Texas. Studies in Archeology 22. Texas Archeological Research Laboratory, The University of Texas at Austin.

Blair, W. Frank

1950 The Biotic Provinces of Texas. The Texas Journal of Science 2(1):93-117.

Blake, Marie E., and Terri Myers

2000 After Slavery: The Rubin Hancock Farmstead, 1880-1916, Travis County, Texas. Reports of Investigations No. 125. Prewitt and Associates, Inc., Austin.

Bureau of Economic Geology

1974 Geologic Atlas of Texas, Austin Sheet. Second printing 1981. Bureau of Economic Geology, The University of Texas at Austin.

Clark, John W., Jr.

1985a Archaeological Testing and Preliminary Archival Investigations of the Ruben Hancock Site, 41TV875, Travis County, Texas. Highway Division, Texas State Department of Highways and
Public Transportation, Austin.

1985b Research Design for Mitigation of the Ruben Hancock Site, 41TV875, Travis County, Texas. Highway Division, Texas State Department of Highways and Public Transportation, Austin.

Collins, Michael B.

1995 Forty Years of Archeology in Central Texas. Bulletin of the Texas Archeological Society 66:361-400.

Collins, Michael B., Bruce Ellis, and Cathy Dodt-Ellis 1990 Excavations at the Camp Pearl Wheat Site (41KR243): An Early Archaic Campsite on Town Creek, Kerr County, Texas. Studies in Archeology 6. Texas Archeological Research Laboratory, The University of Texas at Austin.

Ellis, Linda Wootan, G. Lain Ellis, and Charles D. Frederick

1995 Implications of Environmental Diversity in the Central Texas Archeological Region. Bulletin of the Texas Archeological Society 66:401-426.

Garner, L. E., and K. P. Young

1976 Environmental Geology of the Austin Area: An Aid to Urban Planning. Bureau of Economic Geology, The University of Texas at Austin.

Goode, Glenn T.

1991 Late Prehistoric Burned Rock Middens in Central Texas. In The Burned Rock Middens of Texas: An Archeological Symposium, edited by Thomas R. Hester, pp. 71-93. Studies in Archeology 13. Texas Archeological Research Laboratory, The University of Texas at Austin.

Headrick, Pamela

1993 A Draft Evaluation of Documentation and Materials from 41TV875, The Ruben Hancock Farmstead, Travis County, Texas. Texas Archeological Research Laboratory, The University of Texas at Austin.

Huebner, Jeffrey A.

1991 Late Prehistoric Bison Populations in Central and South Texas. Plains Anthropologist 36(137):343-358. 
Jelks, Edward B.

1962 The Kyle Site: A Stratified Central Texas Aspect Site in Hill County, Texas. Archaeology Series No. 5. Department of Anthropology, The University of Texas at Austin.

Johnson, Elmer H.

1931 The Natural Regions of Texas. Bureau of Business Research, Monograph No. 8 and The University of Texas Bulletin No. 3113. The University of Texas at Austin.

Johnson, LeRoy, and Glenn T. Goode

1994 A New Try at Dating and Characterizing Holocene Climates, as Well as Archeological Periods, on the Eastern Edwards Plateau. Bulletin of the Texas Archeological Society 65:1-651.

Kleinbach, Karl, Gemma Mehalchick, James T. Abbott, and J. Michael Quigg

1995 Other Analyses. In NRHP Significance Testing of 57 Prehistoric Archeological Sites on Fort Hood, Texas, Volume II, edited by James T. Abbott and W. Nicholas Trierweiler, pp. 765-842. Research Report 34. Archeological Resource Management Series,. United States Army, Fort Hood.

Mallouf, Robert J.

1989 A Clovis Quarry Workshop in the Callahan Divide: The Yellow Hawk Site, Taylor County, Texas. Plains Anthropologist 34:81-103.

Masson, Marilyn A., and Michael B. Collins

1995 The Wilson-Leonard Site (41WM235). Cultural Resource Management News and Views 7(1):6-10. Texas Historical Commission, Austin.

McKinney, Wilson W.

1981 Early Holocene Adaptations in Central and Southwestern Texas: The Problem of the Paleoindian-Archaic Transition. Bulletin of the Texas Archeological Society 52:91-120.

Miller, Kevin Anthony

1993 A Study of Prehistoric Biface Caches from Texas. Unpublished Master's thesis, The University of Texas at Austin.

Nordt, Lee C., Thomas W. Boutton, Charles T. Hallmark, and Michael R. Waters
1994 Late Quaternary Vegetation and Climate Changes in Central Texas Based on the Isotopic Compostion of Organic Carbon. Quaternary Research 41:109-120.

Prewitt, Elton R.

1981 Cultural Chronology in Central Texas. Bulletin of the Texas Archeological Society 52:65-89.

1985 From Circleville to Toyah: Comments on Central Texas Chronology. Bulletin of the Texas Archeological Society 54:201-238.

1995 Distributions of Typed Projectile Points in Texas. Bulletin of the Texas Archeological Society 66:83-173.

Story, Dee Ann

1985 Adaptive Strategies of Archaic Cultures of the West Gulf Coastal Plain. In Prehistoric Food Production in North America, edited by Richard I. Ford, pp. 1956. Anthropological Papers No. 75. Museum of Anthropology, University of Michigan, Ann Arbor.

Toomey, Rickard S., III, Michael D. Blum, and Salvatore Valastro Jr.

1993 Late Quaternary Climates and Environments of the Edwards Plateau, Texas. Global and Planetary Change 7:299-320.

Tunnell, Curtis

1978 The Gibson Lithic Cache from West Texas. Office of the State Archeologist Report 30. Texas Historical Commission, Austin.

Weir, Frank A.

1976 The Central Texas Archaic. Unpublished Ph.D. dissertation, Department of Anthropology, Washington State University, Pullman.

Werchan, Leroy E., A. C. Lowther, and Robert N. Ramsey

1974 Soil Survey of Travis County, Texas. U.S. Depertment of Agriculture, Soil Conservation Service, in cooperation with Texas Agriculture Experiment Station.

Willey, Gordon R., and Philip Phillips 1958 Method and Theory in American Archaeology. University of Chicago Press, Chicago. 


\title{
APPENDIX: INVENTORY OF PREHISTORIC ARTIFACTS BY PROVENIENCE
}

\author{
E. Frances Gadus
}




\begin{tabular}{|c|c|c|c|c|c|c|c|c|c|c|c|c|c|c|c|c|c|c|c|c|c|c|c|c|c|c|}
\hline 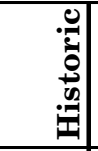 & $\stackrel{\infty}{-1}$ & 0 & 0 & 10 & $\infty$ & คิ & $\infty$ & 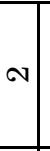 & 0 & 年 & 0 & 0 & 0.0 & o & 0 & 0 & 0.0 & $\stackrel{\sim}{\sim}$ & 0 & 0 & -1 & 0 & 0 & 0 & 0 & $\gamma$ \\
\hline 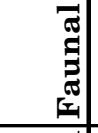 & $\infty$ & 0 & 0 & 0 & o & $\sim$ & 0 & 0 & 0 & -1 & 0 & 0 & 0 & 0 & 00 & 0 & 0.0 & 0 & 0 & 0 & 0 & 0 & 0 & & 0 & b \\
\hline 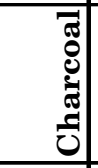 & 0 & 0 & 0 & 0 & 인 & 0 & 0 & -1 & 0 & 0 & 0 & 0 & 0.0 & 010 & 0 & 0.0 & 0.0 & 0 & 0 & 0 & 0 & 0 & 0 & 0 & 0 & b \\
\hline 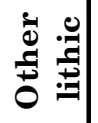 & 20 & $\stackrel{ }{\sim}$ & 20 & $\stackrel{\infty}{-1}$ & ล & $\sim$ & 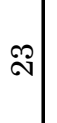 & -1 & $\sim$ & 过 & $\infty$ & + & -10 & $\curvearrowright$ & o & 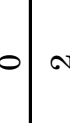 & $\sim|N|$ & $\infty$ & $\stackrel{10}{-1}$ & 이 & $\nabla$ & -1 & 0 & -1 & 0 & $b$ \\
\hline 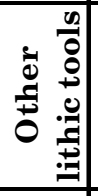 & 0 & 0 & 0 & 0 & 인 & 0 & 0 & 0 & 0 & $\sim$ & -1 & 0 & 010 & 0 & 0.0 & $\begin{array}{lll}0 & 0\end{array}$ & 0 & 0 & -1 & $\infty$ & 0 & 0 & 0 & $\sim$ & 0 & P \\
\hline $\begin{array}{l}\quad \text { a } \\
.5 \\
0 \\
0\end{array}$ & 0 & -1 & -1 & $\infty$ & 0 & 0 & 0 & 0 & 0 & 0 & 0 & 0 & 0 & 0 & -10 & \begin{tabular}{c|c}
$*$ & 0
\end{tabular} & 0 & 0 & -1 & $\sim$ & $N$ & 0 & 0 & 0 & 0 & P \\
\hline 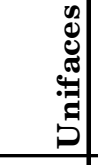 & 0 & 0 & 0 & 0 & 0 & 0 & 0 & 이 & -1 & 0 & 0 & 0 & 0.0 & 0 & 0 & 0.0 & 0.0 & 0 & 0 & 0 & 0 & 0 & 0 & 0 & 0 & D \\
\hline 品 & 10 & 0 & -1 & 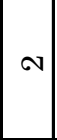 & 0 & + & $\sim$ & -1 & 0 & $\infty$ & $\stackrel{0}{-1}$ & $\infty$ & $\psi^{\prime}$ & 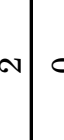 & 0 & -15 & -0 & + & $\sim$ & + & $\triangle$ & 20 & $\infty$ & 0 & 0 & b \\
\hline \begin{tabular}{l|}
0 \\
0 \\
0 \\
$\vdots$ \\
0
\end{tabular} & 0 & 0 & 0 & 0 & o & 0 & -1 & 인 & 0 & -1 & 0 & 0 & 0.0 & 0 & 0 & 0. & -10 & -1 & 0 & $\infty$ & $N$ & $N$ & -1 & 0 & 0 & D \\
\hline 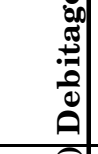 & 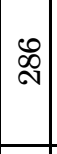 & 年 & 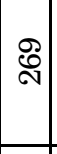 & \begin{tabular}{|l|}
2 \\
0 \\
8
\end{tabular} & - & న్లి & 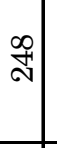 & $\begin{array}{c}\infty \\
\stackrel{2}{9} \\
\rightarrow\end{array}$ & 年 & 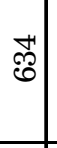 & $\begin{array}{l}\Omega \\
\forall\end{array}$ & |م & $\begin{array}{l}0 \\
-\end{array}$ & స్తి & 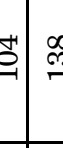 & 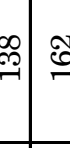 & \begin{tabular}{l|l}
0 \\
0
\end{tabular} & हొ & 洛 & บิ| & $\stackrel{2}{=}$ & 득 & త્తి & $\begin{array}{l}\infty \\
0 \\
-1 \\
-1\end{array}$ & $\infty$ & $\frac{2}{2}$ \\
\hline 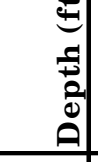 & $\begin{array}{l} \\
\\
10 \\
0 \\
0 \\
0 \\
\end{array}$ & 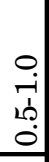 & 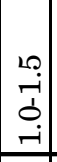 & \begin{tabular}{|l|}
1 \\
0 \\
0 \\
0 \\
\end{tabular} & $\begin{array}{c}0 \\
\dot{1} \\
10 \\
0 \\
0\end{array}$ & $\begin{array}{l}1 \\
0 \\
0 \\
\vdots \\
0\end{array}$ & 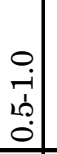 & 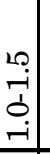 & $\begin{array}{l}0 \\
\text { o } \\
\text { Lे } \\
\text { Lे } \\
\end{array}$ & \begin{tabular}{l|}
10 \\
0 \\
$\vdots$ \\
0 \\
\end{tabular} & 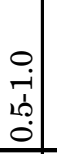 & 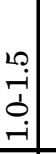 & 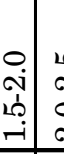 & 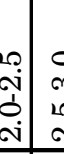 & 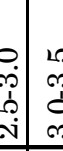 & 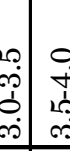 & 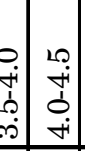 & a. & & $\begin{array}{l}0 \\
0 \\
\vdots \\
\vdots \\
0 \\
\end{array}$ & $\begin{array}{l}0 \\
\dot{1} \\
10 \\
0 \\
0\end{array}$ & : & 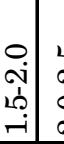 & 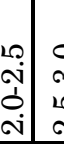 & 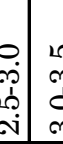 & $\begin{array}{l}0 \\
\dot{p} \\
\vdots \\
\dot{p}\end{array}$ \\
\hline 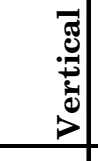 & \begin{tabular}{r|}
-1 \\
-1 \\
0 \\
$د$ \\
0 \\
-1 \\
\end{tabular} & $\begin{array}{l}0 \\
0 \\
0 \\
\Delta \\
0 \\
-1 \\
\end{array}$ & 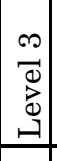 & 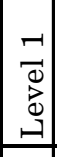 & 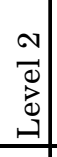 & 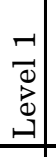 & $\begin{array}{l}\sim \\
\stackrel{0}{0} \\
\stackrel{0}{0} \\
\unlhd \\
\end{array}$ & $\begin{array}{l}\infty \\
0 \\
0 \\
0 \\
0 \\
\\
\end{array}$ & 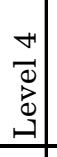 & \begin{tabular}{l}
-1 \\
\multicolumn{2}{|c}{} \\
$\stackrel{0}{0}$ \\
. \\
\end{tabular} & $\begin{array}{l}N \\
D \\
0 \\
\Delta \\
\\
\end{array}$ & $\begin{array}{l}\infty \\
0 \\
0 \\
0 \\
0 \\
\\
\end{array}$ & 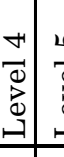 & 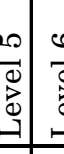 & 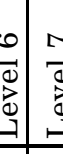 & 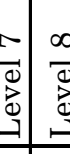 & 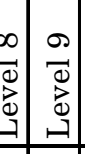 & 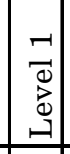 & 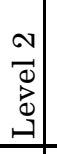 & $\begin{array}{l}0 \\
0 \\
0 \\
0 \\
\stackrel{0}{-1} \\
\end{array}$ & $\begin{array}{l}+ \\
\\
\stackrel{0}{0} \\
. \\
\end{array}$ & 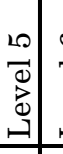 & $\begin{array}{l}0 \\
0 \\
0 \\
0 \\
0 \\
\\
\end{array}$ & 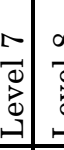 & 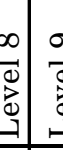 & 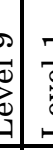 \\
\hline 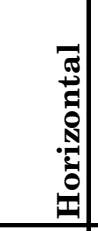 & $\begin{array}{l}8 \\
0 \\
z \\
\vdots \\
10 \\
1 \\
0 \\
0 \\
10 \\
0 \\
\end{array}$ & 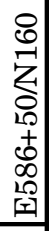 & $\begin{array}{l}8 \\
0 \\
z \\
\vdots \\
10 \\
1 \\
0 \\
0 \\
10 \\
0 \\
\end{array}$ & 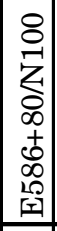 & $\begin{array}{l}8 \\
0 \\
z \\
0 \\
\infty \\
+ \\
0 \\
0 \\
10 \\
0 \\
\end{array}$ & 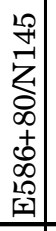 & 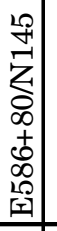 & 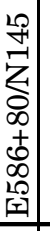 & 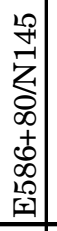 & $\begin{array}{l}18 \\
0 \\
2 \\
- \\
\infty \\
+ \\
0 \\
0 \\
0 \\
0 \\
\end{array}$ & 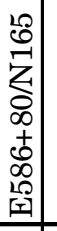 & 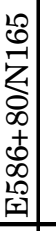 & 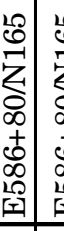 & 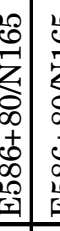 & 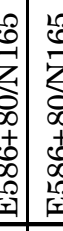 & 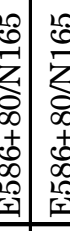 & 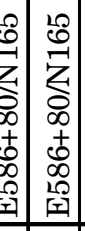 & 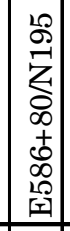 & 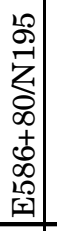 & 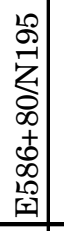 & 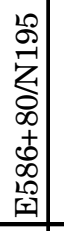 & 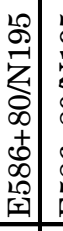 & 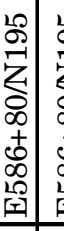 & 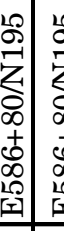 & 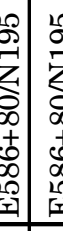 & 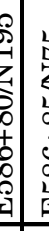 \\
\hline 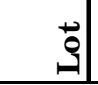 & 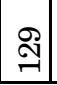 & 苟 & \begin{tabular}{|c|c}
$\widehat{\alpha}$ \\
-1 \\
\end{tabular} & $\widehat{\infty}$ & 위 & $\stackrel{ }{\forall}$ & 果 & 可 & $\underset{\substack{\infty \\
+}}{ }$ & 인 & ำ & مْ & \begin{tabular}{l|l}
10 \\
10
\end{tabular} & 10.5 & : & \begin{tabular}{c|c}
0 \\
10
\end{tabular} & 8 & $\infty$ & 0 & 吾 & Iี & $\stackrel{9}{\ddagger}$ & $\mathbb{Z}$ & $\stackrel{7}{7}$ & 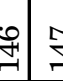 & \pm \\
\hline
\end{tabular}




\begin{tabular}{|c|c|c|c|c|c|c|c|c|c|c|c|c|c|c|c|c|c|c|c|c|c|c|c|c|c|c|c|}
\hline 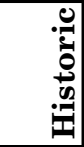 & 20 & 0 & 0 & 0 & $\stackrel{\simeq}{-1}$ & 0 & 0 & 0 & ฉి & 0 & 0 & 0 & 0 & 0 & 0 & 0 & 0 & 0 & + & ల్లి & 20 & 0 & 安 & 0 & $0 \mid \mathrm{N}$ & 0 & $\stackrel{\Upsilon}{2}$ \\
\hline 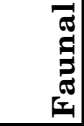 & 0 & 이 & 0 & 이 & 0 & 0 & 0 & 0 & -1 & 0 & 0 & 0 & 0 & 0 & 0 & 0 & 0 & 0 & 0 & $\sim$ & 0 & 0 & 00 & 0 & 0 & 0 & $\infty$ \\
\hline 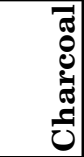 & 0 & 인 & 0 & 0 & 0 & 0 & 0 & 0 & 0 & 0 & 0 & 0 & 0 & 0 & 0 & 0 & 0 & 0 & 0 & 0 & 010 & 0 & 0 & 0 & 0 & 0 & 0 \\
\hline 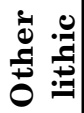 & ه & 10 & $\infty$ & 0 & 10 & 0 & 黑 & 0 & ஓ) & 年 & 0 & N & 0 & 0 & $\stackrel{\infty}{-1}$ & 0 & -1 & $\sim$ & $\sim$ & 吕? & $\exists$ & -1 & 1ి & 0 & $\stackrel{9}{-}$ & 6 & 0 \\
\hline 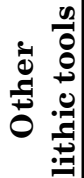 & 0 & 0 & 0 & 0 & 0 & 0 & 0 & $\rightarrow$ & $\sim$ & -1 & 0 & 0 & 0 & 0 & 인 & 0 & 0 & -1 & 0 & + & 0 & 0 & $\sim$ & 0 & 0. & \begin{tabular}{|c|}
-1 \\
\end{tabular} & 0 \\
\hline $\begin{array}{l}0 \\
\stackrel{n}{0} \\
0 \\
0\end{array}$ & 인 & 인 & 0 & 0 & $\sim$ & 0 & -1 & 0 & 0 & 0 & 0 & 0 & 0 & 0 & 0 & 0 & 0 & 0 & 0 & 0 & $\sim$ & 0 & $\infty$ & 0 & 0 & -1 & 6 \\
\hline 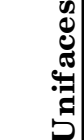 & 0 & 이 & 0 & 0 & $\sim$ & 0 & 0 & 0 & 0 & 0 & 0 & 0 & 0 & 0 & 0 & 0 & 0 & 0 & 0 & 0 & 0 & 0 & 0 & 0 & 0 & 0 & 0 \\
\hline 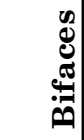 & $\sim$ & 0 & 0 & o) & $\infty$ & -1 & 0 & 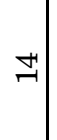 & $H$ & $\sim$ & + & 0 & 0 & $\forall$ & $H$ & 0 & $\infty$ & 0 & 0 & $\sim$ & $H$ & 0 & 6 & 0 & $\sigma$ & $\infty$ & $\stackrel{\mathscr{m}}{\sim}$ \\
\hline $\begin{array}{l}0 \\
0 \\
0 \\
0 \\
0\end{array}$ & -1 & 0 & 0 & 0 & -1 & $\infty$ & -1 & -1 & 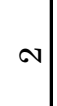 & 0 & 0 & 0 & 0 & -1 & 0 & 0 & 0 & 0 & 0 & + & 0 & 0 & 0 & 0 & 0 & \begin{tabular}{r|r}
-1 & -1
\end{tabular} & -1 \\
\hline 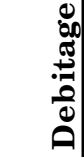 & 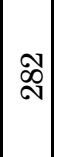 & 机 & $\stackrel{\stackrel{P}{二}}{-}$ & 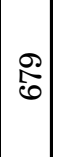 & 윙 & 索 & \begin{tabular}{|c|c}
5 \\
0
\end{tabular} & 용 & 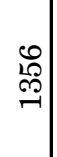 & 点 & $\begin{array}{l}- \\
\sigma\end{array}$ & 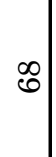 & 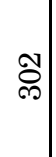 & 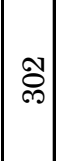 & 芯 & $\stackrel{\mathfrak{N}}{\mathrm{N}}$ & రి & $\stackrel{\circ}{\infty}$ & 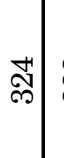 & \begin{tabular}{l|l}
$\infty$ \\
$\infty$ \\
$\infty$
\end{tabular} & ?̊) & 와 & 范 & $\stackrel{\Omega}{2}$ & 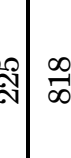 & 0 & 등 \\
\hline 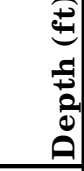 & \begin{tabular}{|c|}
0 \\
0 \\
\\
1 \\
0 \\
0 \\
\end{tabular} & 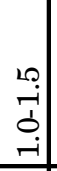 & & \begin{tabular}{|l|}
20 \\
0 \\
0 \\
0 \\
\end{tabular} & $\begin{array}{c}0 \\
0 \\
\\
1 \\
0 \\
0 \\
\end{array}$ & \begin{tabular}{|c|} 
\\
0 \\
-1 \\
0 \\
0 \\
-1 \\
\end{tabular} & 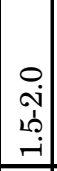 & 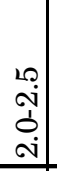 & $\begin{array}{l}20 \\
0 \\
0 \\
0 \\
\end{array}$ & 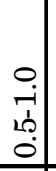 & 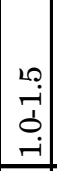 & 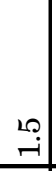 & $\begin{array}{c}0 \\
0 \\
0 \\
1 \\
1 \\
\\
-1 \\
\end{array}$ & \begin{tabular}{|c|}
20 \\
$i$ \\
0 \\
0 \\
$i$ \\
\end{tabular} & $\begin{array}{c}0 \\
\infty \\
\infty \\
i \\
i \\
i \\
\end{array}$ & 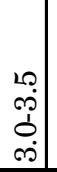 & 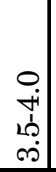 & $\begin{array}{l}10 \\
\stackrel{1}{+} \\
0 \\
\dot{+} \\
\end{array}$ & \begin{tabular}{l|l} 
& \\
10 \\
0 \\
0 \\
0
\end{tabular} & 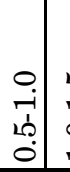 & 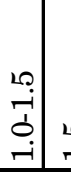 & 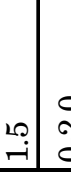 & \begin{tabular}{l|l} 
& 15 \\
0 & $a$ \\
$\dot{j}$ & 0 \\
0 & 0 \\
0
\end{tabular} & 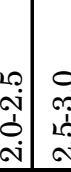 & 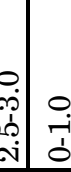 & 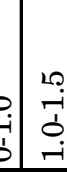 & مُ \\
\hline 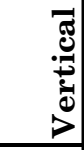 & 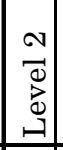 & $\begin{array}{l}\infty \\
0 \\
0 \\
0 \\
0 \\
\end{array}$ & & 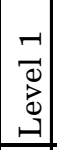 & 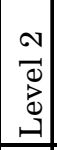 & 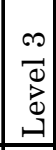 & \begin{tabular}{|l|} 
\\
0 \\
0 \\
0 \\
0 \\
\end{tabular} & \begin{tabular}{r|}
20 \\
0 \\
0 \\
0 \\
\\
\end{tabular} & 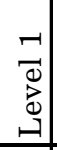 & 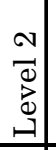 & 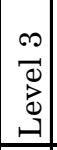 & $\begin{array}{c}\infty \\
0 \\
\stackrel{0}{0} \\
\stackrel{0}{0} \\
\\
\end{array}$ & $\begin{array}{l}+1 \\
d \\
د \\
0 \\
\\
\end{array}$ & 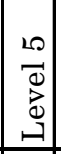 & $\begin{array}{l}0 \\
0 \\
0 \\
0 \\
0 \\
\end{array}$ & 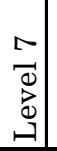 & 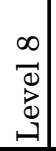 & $\begin{array}{l}0 \\
0 \\
0 \\
0 \\
9 \\
\end{array}$ & 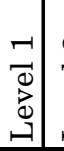 & 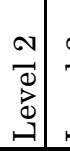 & 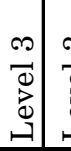 & 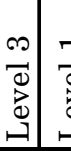 & 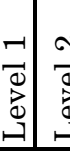 & 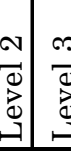 & 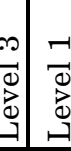 & 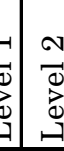 & $\begin{array}{l}-1 \\
\stackrel{0}{0} \\
\stackrel{0}{త} \\
\end{array}$ \\
\hline 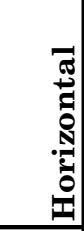 & 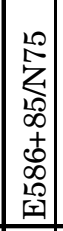 & $\begin{array}{l}10 \\
5 \\
Z \\
2 \\
\infty \\
+ \\
0 \\
0 \\
10 \\
0\end{array}$ & 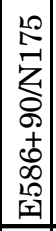 & 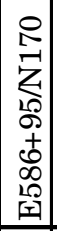 & 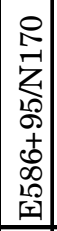 & 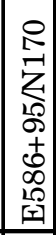 & 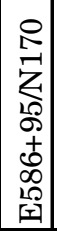 & 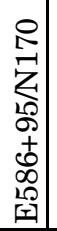 & $\begin{array}{l}10 \\
5 \\
2 \\
2 \\
2 \\
0 \\
+ \\
0 \\
20 \\
10 \\
10 \\
\mid\end{array}$ & 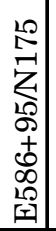 & $\begin{array}{l}10 \\
5 \\
2 \\
2 \\
2 \\
0 \\
+ \\
0 \\
20 \\
10 \\
10 \\
\mid\end{array}$ & $\begin{array}{l}10 \\
2 \\
2 \\
2 \\
2 \\
0 \\
+ \\
0 \\
0 \\
10 \\
10\end{array}$ & 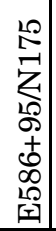 & 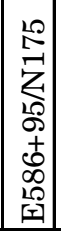 & $\begin{array}{l}10 \\
2 \\
2 \\
2 \\
2 \\
0 \\
+ \\
0 \\
20 \\
10 \\
0\end{array}$ & 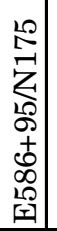 & 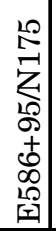 & 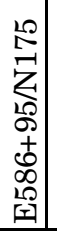 & 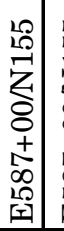 & 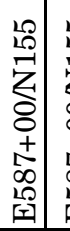 & 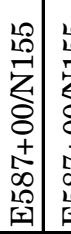 & 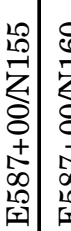 & 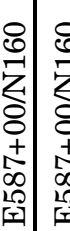 & 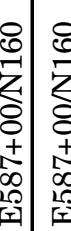 & 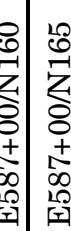 & 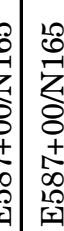 & 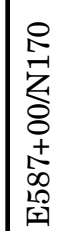 \\
\hline$\vec{\circ}$ & $\mid \begin{array}{l}\infty \\
0 \\
0\end{array}$ & 의 이 & 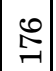 & 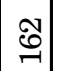 & 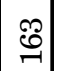 & 苞 & $\mid \begin{array}{l}0 \\
0 \\
0\end{array}$ & $\underline{6}$ & \begin{tabular}{c}
0 \\
\multirow{-}{*}{} \\
-1
\end{tabular} & 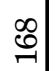 & 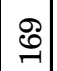 & 옥 & 독 & 胥 & $\mid \begin{array}{c}-1 \\
-0 \\
-1\end{array}$ & 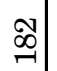 & $\begin{array}{l}\mathscr{\infty} \\
\stackrel{\infty}{\sim}\end{array}$ & 萬 & 苟 & 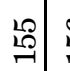 & $\begin{array}{ll}0 \\
10\end{array}$ & 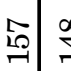 & $\stackrel{\infty}{+}$ & $\stackrel{-\sigma}{\sigma}$ & 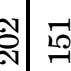 & 苟 & $\stackrel{P}{\exists}$ \\
\hline
\end{tabular}




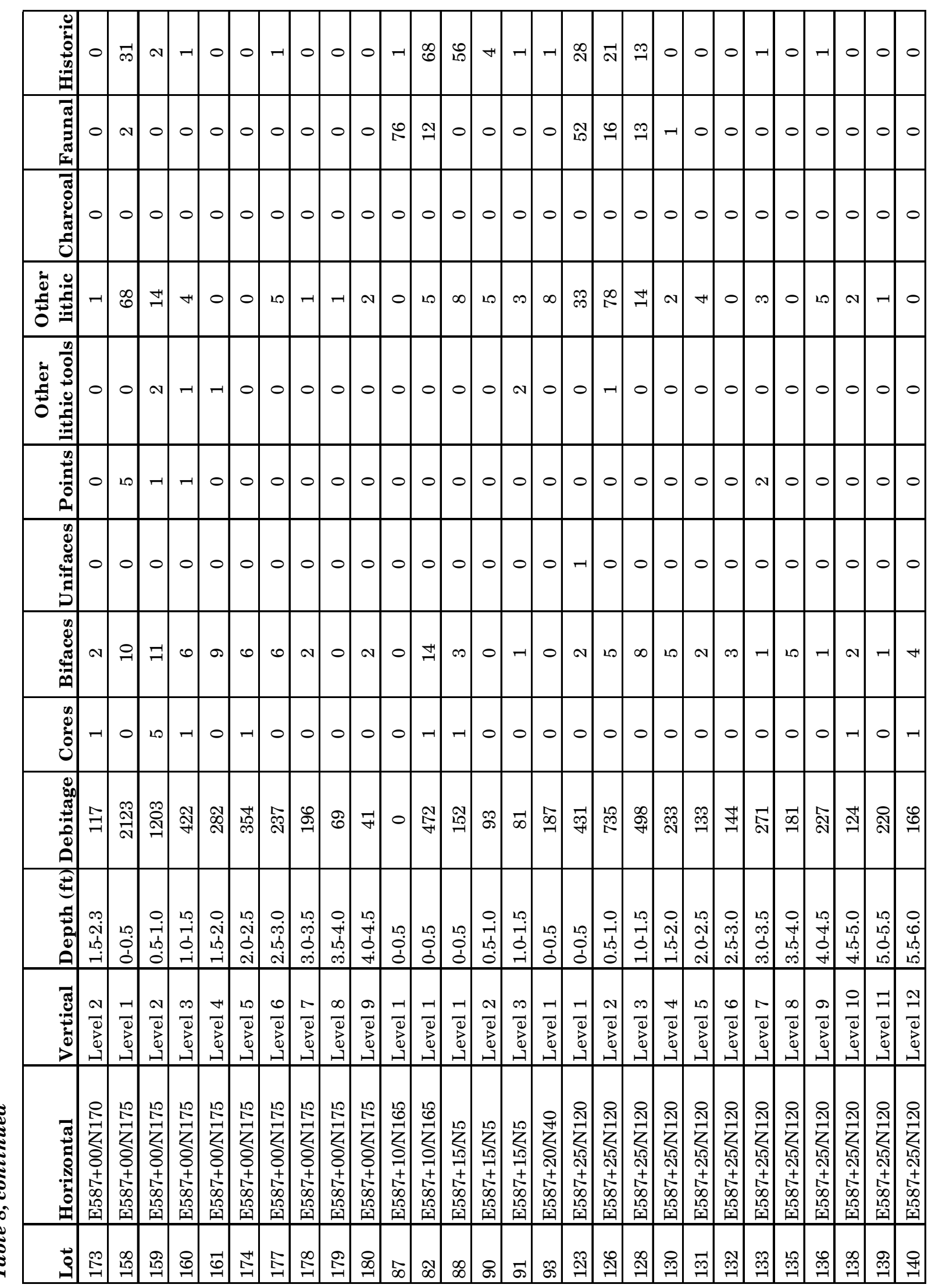




\begin{tabular}{|c|c|c|c|c|c|c|c|c|c|c|c|c|c|c|c|c|c|c|c|c|c|c|c|c|c|c|}
\hline 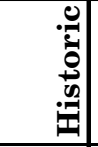 & मे & $\sim$ & 0 & 인 & -1 & 0 & 0 & 인 & 0 & 0 & 0 & 0 & $\begin{array}{l}\infty \\
\rightarrow \\
-\end{array}$ & -1 & 0 & 0 & 0.0 & \begin{tabular}{l|l}
0 & 10
\end{tabular} & 0 & 0 & 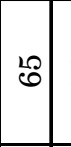 & กิ & -1 & 0 & 0 & \\
\hline 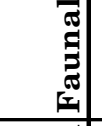 & $\infty$ & 0 & 0 & $\sim$ & 0 & 0 & 0 & 인 & 0 & 0 & 0 & 0 & -1 & 0 & 0 & 0 & 0.0 & 0.0 & 0 & 0 & 10 & -1 & 0 & 0 & 0 & o \\
\hline 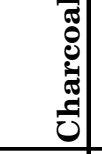 & 0 & 0 & 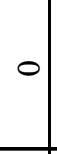 & 0 & 0 & 0 & $\infty$ & 0 & 0 & 0 & 0 & 0 & 인 & 인 & 0 & 0 & 0.0 & 0 & 0 & 0 & 0 & 인 & 인 & 0 & 0 & P \\
\hline 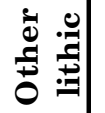 & $\stackrel{\infty}{+}$ & $\stackrel{\infty}{\infty}$ & $\sim$ & 10 & 20 & $\sim$ & 20 & 0 & 0 & 0 & $\infty$ & 0 & $\infty$ & 10 & 위 & $\infty \begin{array}{lll}\infty & 0\end{array}$ & $\infty 10$ & 0. & -7 & 0 & $\stackrel{10}{\infty}$ & 番 & 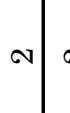 & N & -1 & \\
\hline 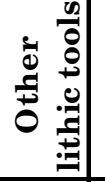 & 0 & 잉 & 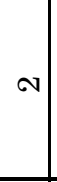 & 0 & 이 & 0 & 0 & 이 & 0 & 0 & 0 & 0 & 0 & 0 & 0 & 0.0 & 0.0 & $\begin{array}{lll}0 & 0\end{array}$ & 0 & 0 & $\infty$ & 10 & 0 & 0 & 0 & o \\
\hline 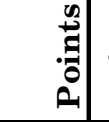 & 0 & $\infty$ & 0 & 0 & 인 & 0 & $\neg$ & 0 & 0 & 0 & 0 & 0 & 10 & 0 & 0 & 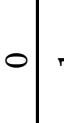 & -10 & 0 & 0 & 0 & 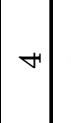 & -1 & 0 & 0 & 0 & o \\
\hline 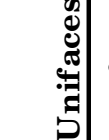 & 0 & 0 & 0 & 0 & 이 & 0 & 0 & 이 & 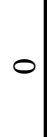 & 0 & 0 & 0 & 인 & -1 & 0 & 0 & 0.0 & \begin{tabular}{l|l}
0 & 0
\end{tabular} & 0 & 0 & 0 & 0 & 0 & 0 & 0 & \\
\hline
\end{tabular}

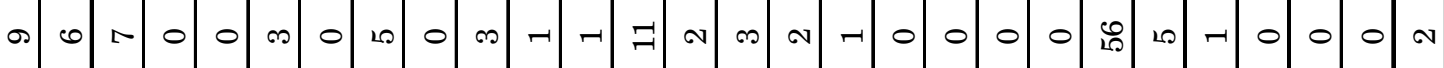

$\begin{array}{llllllllllllllllllllllllllllllll}0 & 0 & 0 & -1 & 0 & 0 & 0 & -1 & 0 & 0 & 0 & 0 & 0 & 0 & + & 0 & 0 & 0 & 0 & 0 & 0 & 0 & 0 & N & -1 & 0 & 0 & 0 & 0 & 0\end{array}$

๘)

잉

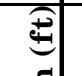

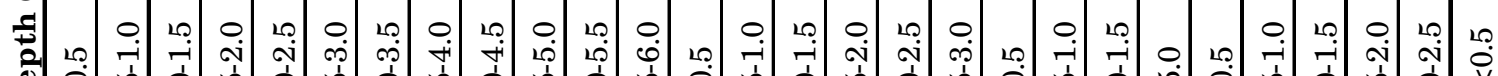

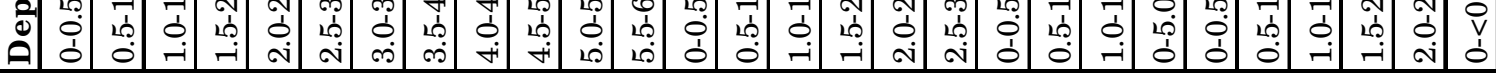

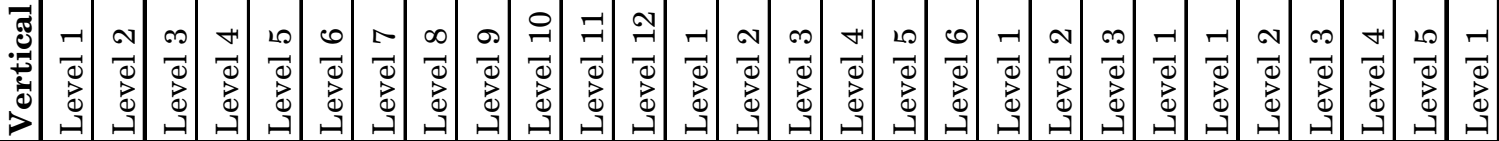

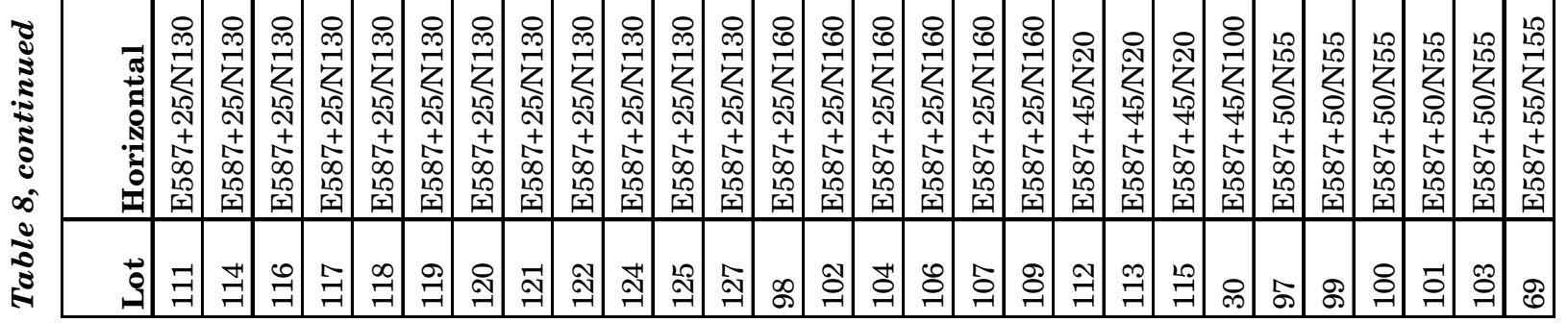


究

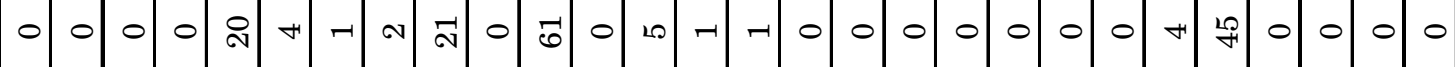
0 - 0 O 0 o

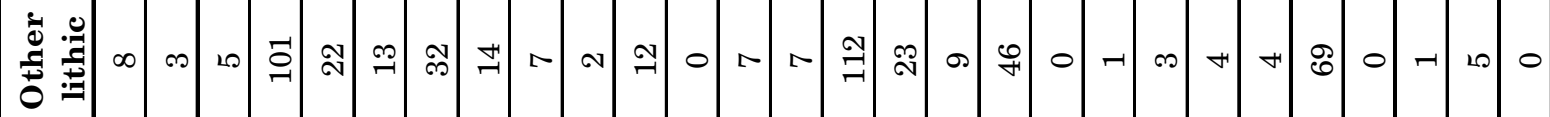

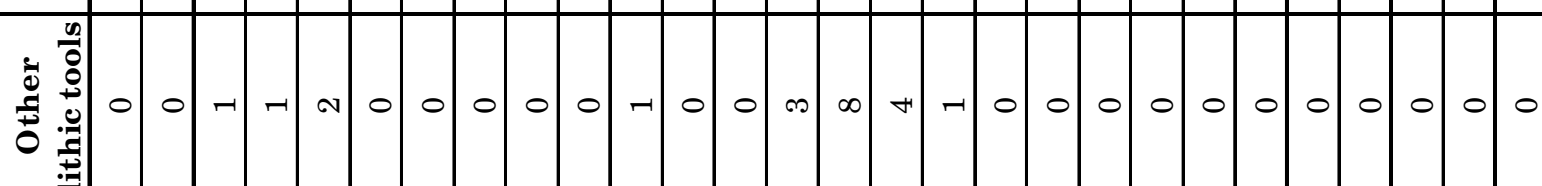

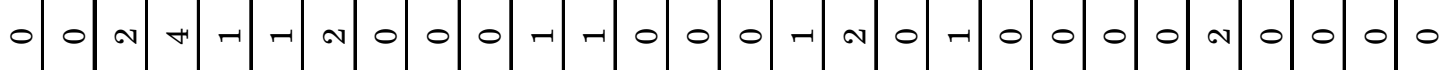

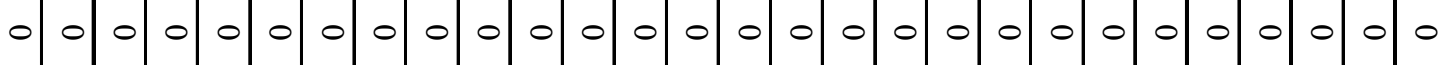

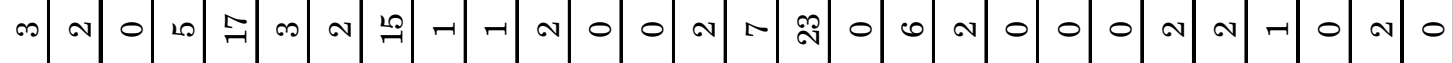

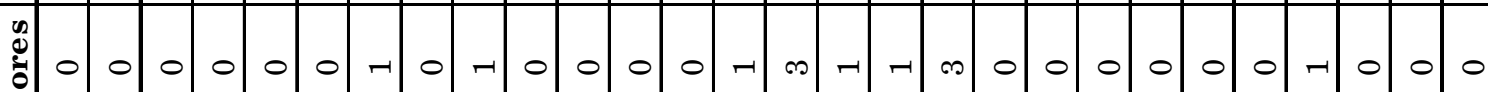
0 \&

है

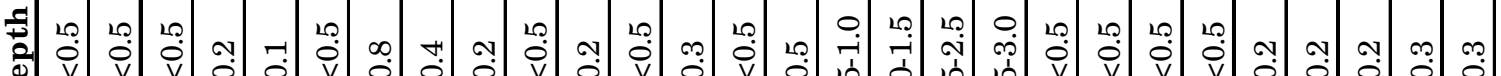

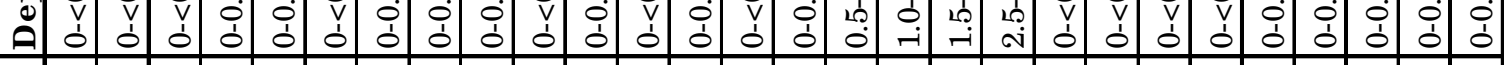

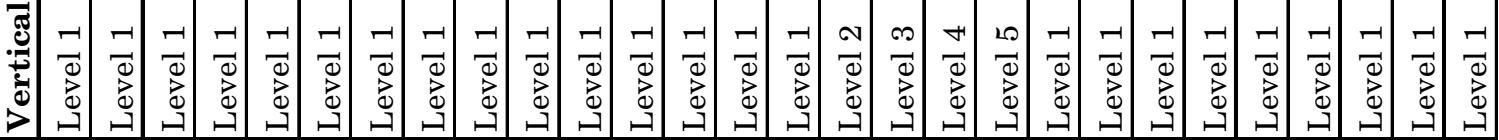

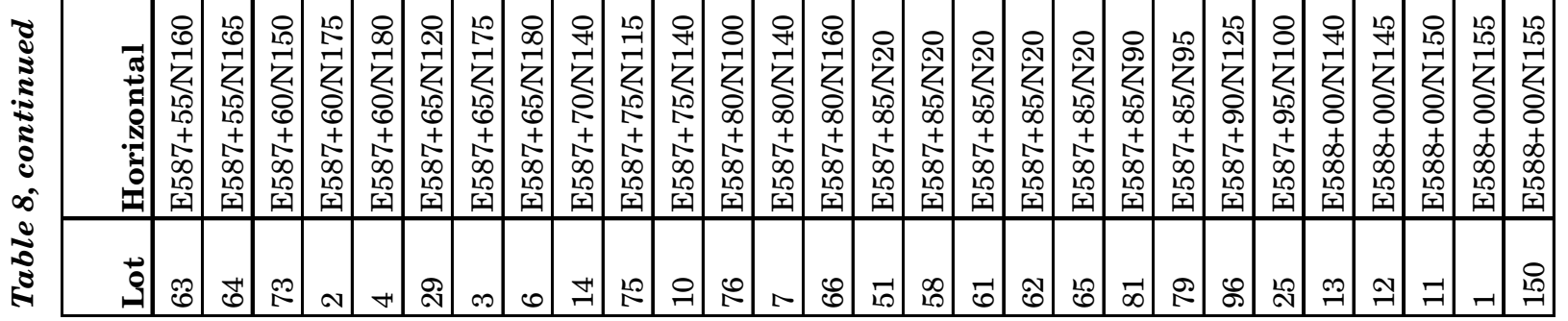




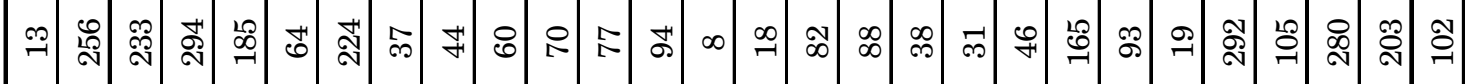

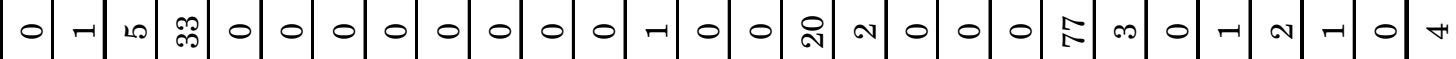

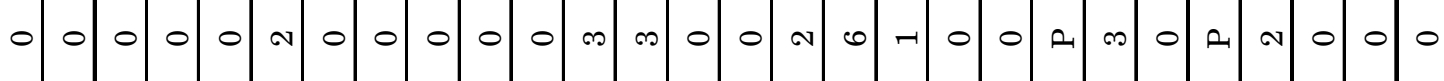

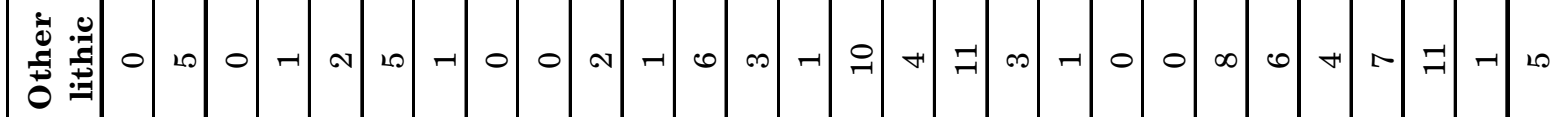

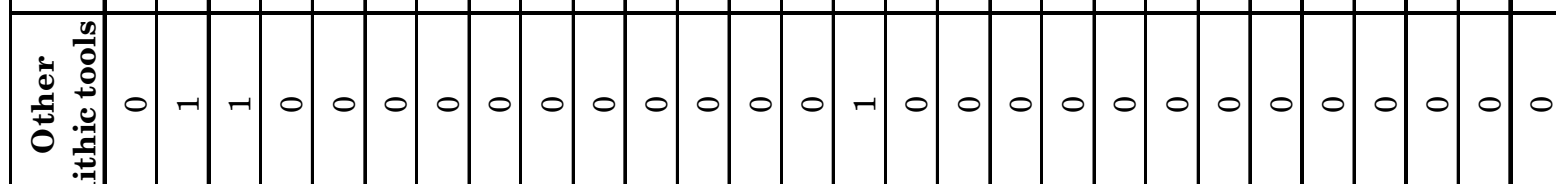

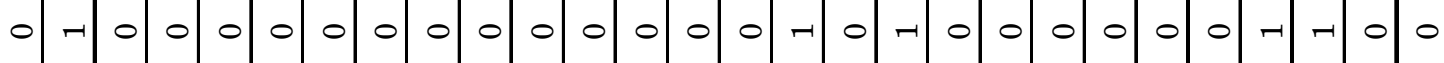

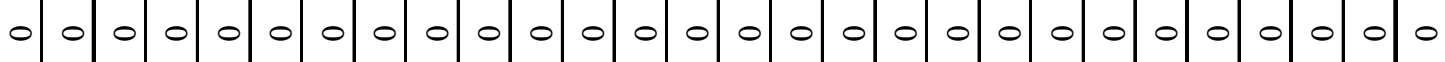

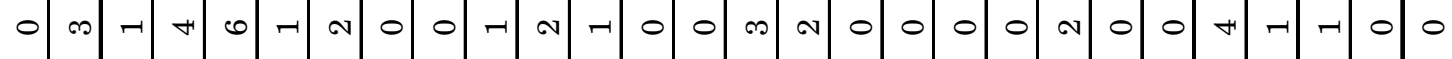
0
0

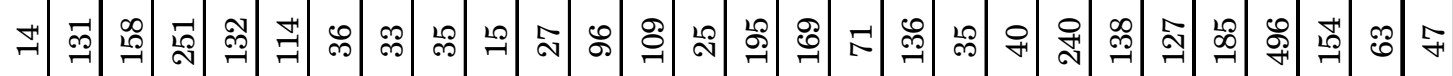

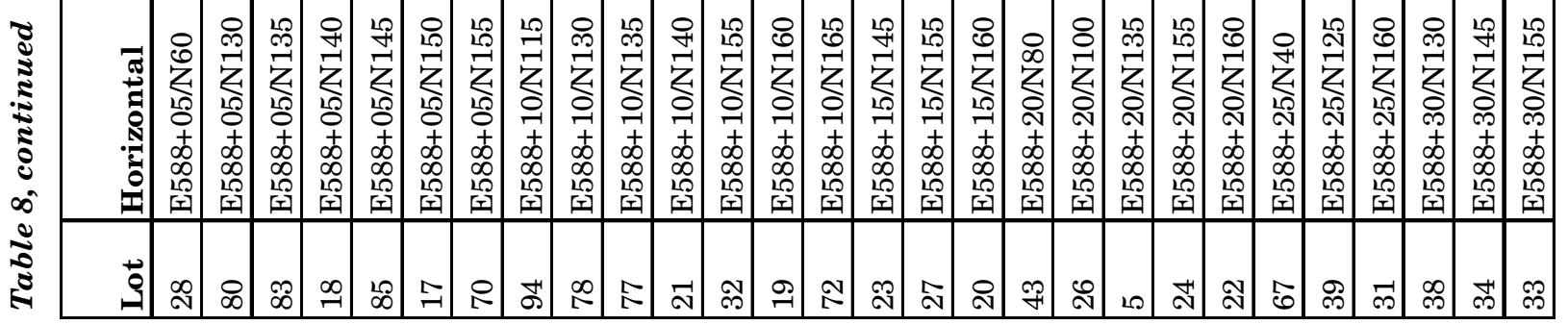




\begin{tabular}{|c|c|c|c|c|c|c|c|c|c|c|c|c|c|c|c|c|c|c|}
\hline 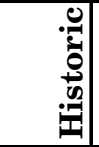 & ळ & $\underset{12}{\stackrel{1}{7}}$ & $\begin{array}{l}10 \\
= \\
=\end{array}$ & $\stackrel{\star N}{\mathrm{~N}}$ & ลิ & $\Rightarrow$ & 0 & N & $\mathscr{m}$ & 守 & $\stackrel{\Omega}{-1}$ & $\overrightarrow{\mathrm{N}}$ & P & ㅇํ & 0 & $\stackrel{\sharp}{N}$ & $\infty$ & $\begin{array}{c}\infty \\
0 \\
\infty \\
\infty \\
\infty\end{array}$ \\
\hline 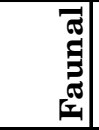 & 0 & 0 & $\sim$ & -1 & 0 & 0 & 0 & 0 & 0 & 20 & $\sim$ & 0 & 0 & 0 & -1 & 0 & -1 & 윔 \\
\hline 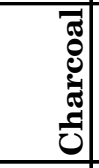 & 0 & + & 0 & 0 & 0 & 0 & 0 & 0 & 0 & 0 & 0 & 0 & 0 & -1 & 0 & 0 & 0 & ภ้ \\
\hline 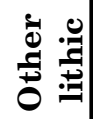 & 0 & $\sim$ & 0 & $\sim$ & $\sigma$ & $\infty$ & $\stackrel{2}{\mathrm{~N}}$ & -1 & 0 & $\sim$ & $\sigma$ & 윽 & 20 & -1 & -1 & 0 & 0 & $\begin{array}{l}\stackrel{0}{2} \\
\stackrel{2}{-}\end{array}$ \\
\hline 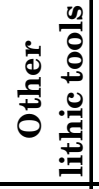 & 0 & 0 & 0 & o & -1 & 0 & -1 & 0 & $\sim$ & -1 & 0 & 0 & 0 & -1 & 0 & 0 & 0 & $\infty$ \\
\hline $\begin{array}{l}0 \\
.0 \\
0 \\
0\end{array}$ & 0 & 0 & 0 & 0 & $\infty$ & 0 & 10 & 0 & 0 & -1 & -1 & -1 & -1 & -1 & -1 & 0 & 0 & $\stackrel{\infty}{\infty}$ \\
\hline 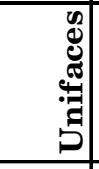 & 0 & 0 & 0 & 0 & 0 & 0 & 0 & 0 & 0 & 0 & 0 & 0 & 0 & 0 & 0 & 0 & 0 & 20 \\
\hline 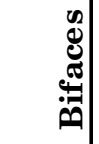 & $\infty$ & 0 & -1 & $\sim$ & 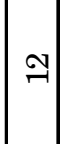 & 0 & $\stackrel{m}{\rightarrow}$ & 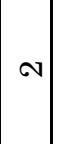 & $\Rightarrow$ & $\infty$ & $\infty$ & N & N & 0 & -1 & 0 & 0 & श్రి \\
\hline \begin{tabular}{l|}
0 \\
0 \\
0 \\
0 \\
0
\end{tabular} & 0 & 0 & o & o & -1 & 0 & 0 & -1 & 0 & $\infty$ & 0 & 0 & -1 & $N$ & 0 & 0 & 0 & $\infty$ \\
\hline 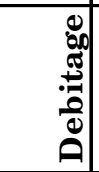 & : & ళి & $\&$ & $\begin{array}{l}\mathscr{0} \\
0 \\
-1\end{array}$ & $\mid \begin{array}{l}\infty \\
\infty \\
\infty\end{array}$ & 标 & 常 & $\begin{array}{l}\infty \\
\stackrel{\infty}{\sim} \\
\end{array}$ & 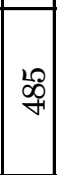 & 6 & : & $\stackrel{\bullet}{\circ}$ & $\begin{array}{c}0 \\
\stackrel{1}{-1}\end{array}$ & \begin{tabular}{l}
0 \\
\multirow{N}{*}{}
\end{tabular} & 0 & 0 & 0 & $\begin{array}{l}10 \\
0 \\
0 \\
10 \\
10\end{array}$ \\
\hline 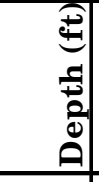 & \begin{tabular}{|c|} 
\\
\\
10 \\
0 \\
0 \\
0 \\
0 \\
\end{tabular} & \begin{tabular}{|c|}
10 \\
0 \\
$\dot{v}$ \\
0 \\
\end{tabular} & \begin{tabular}{|l|}
0 \\
0 \\
$\mathrm{~V}$ \\
0 \\
\end{tabular} & \begin{tabular}{|l|}
10 \\
0 \\
$\mathrm{~V}$ \\
0 \\
\end{tabular} & \begin{tabular}{|l|}
20 \\
0 \\
$\mathrm{~V}$ \\
0 \\
\end{tabular} & \begin{tabular}{|l|}
0 \\
0 \\
$\vdots$ \\
0 \\
\end{tabular} & 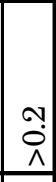 & & $\begin{array}{l}10 \\
0 \\
\mathrm{v} \\
0 \\
0\end{array}$ & \begin{tabular}{|c|}
20 \\
0 \\
$\mathrm{v}$ \\
0 \\
\end{tabular} & \begin{tabular}{|l|}
20 \\
0 \\
$\hat{v}$ \\
0 \\
\end{tabular} & \begin{tabular}{|l|}
20 \\
0 \\
$\mathrm{v}$ \\
0 \\
\end{tabular} & 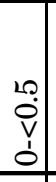 & $\begin{array}{l}10 \\
0 \\
\dot{0} \\
0 \\
0\end{array}$ & & & & \\
\hline 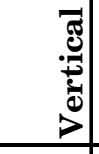 & 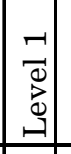 & 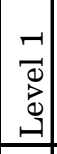 & 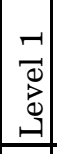 & 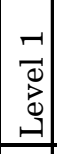 & \begin{tabular}{|l|}
-7 \\
-1 \\
0 \\
0 \\
0 \\
-1 \\
\end{tabular} & 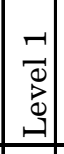 & 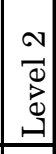 & 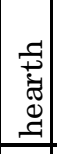 & 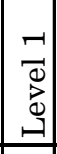 & 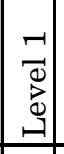 & 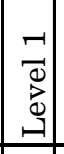 & 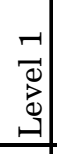 & 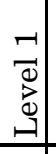 & 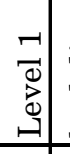 & 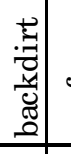 & 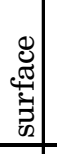 & & \\
\hline 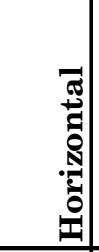 & 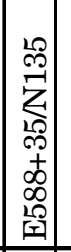 & 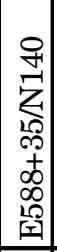 & 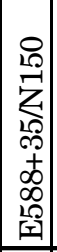 & 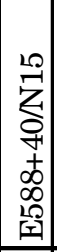 & 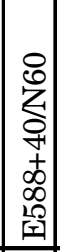 & 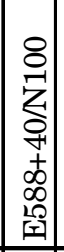 & 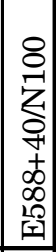 & 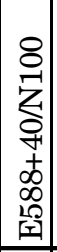 & 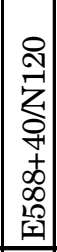 & 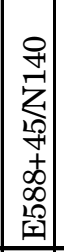 & 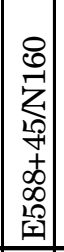 & 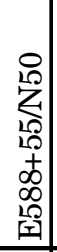 & 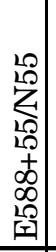 & 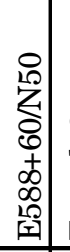 & 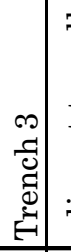 & 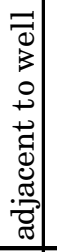 & 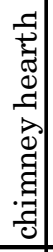 & \\
\hline $\overrightarrow{\mathrm{g}}$ & \begin{tabular}{|c|}
0 \\
0
\end{tabular} \mid & \begin{tabular}{|c|c|}
20 \\
$\mathrm{n}$
\end{tabular} & F & P & $\begin{array}{l}0 \\
0 \\
+1\end{array}$ & 出 & \begin{tabular}{|l} 
量 \\
-1
\end{tabular} & 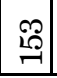 & รั) & $\infty$ & 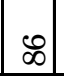 & E & $\infty$ & 志 & \$ & 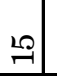 & 28 & 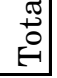 \\
\hline
\end{tabular}


